\title{
3 Political background: The Hanse, urban centres, and foreign authorities
}

The connections between the German cities on the North Sea and the North Atlantic islands date back to the ninth century, when the archdiocese of Bremen-Hamburg was made the centre of missionary actions for Scandinavia. With the gradual establishment of church and state structures in northern Europe, however, these connections were severed. ${ }^{1}$ By the time merchants from these cities (re-)established direct connections with the North Atlantic centuries later, the circumstances had fundamentally changed. ${ }^{2}$ How German merchants interacted with the North Atlantic islands was largely determined by two political realities: the position of the North Atlantic islands as skattlands (tributary lands) of Norway, and the position of the town of Bergen and the Hanseatic Kontor there in the western Scandinavian trade network.

\subsection{Skattlands of the Norwegian king}

The Viking settlers who migrated from Norway to the North Atlantic islands in the ninth and tenth centuries were practically independent at first, even though many had personal ties to the king of Norway and there was frequent contact between these lands. This changed in the course of the twelfth and thirteenth centuries, when the Norwegian king started to bring the Norse-settled lands across the North Sea and the North Atlantic under his control as skattlands, which had to pay tribute. ${ }^{3}$ It is a bit uncertain at what time this exactly happened, as primary sources evidencing this development are scarce. The term skattland in Norwegian legal texts and the division between mainland Norway and its insular territories is first known from the late thirteenth century, ${ }^{4}$ but there are hints that the system existed before that time. Based on the saga

1 Adolf E. Hofmeister, "Die Erzbischöfe von Hamburg-Bremen und das Christentum auf Island”, in Kirche - Kaufmann - Kabeljau: 1000 Jahre Bremer Islandfahrt, ed. Adolf E. Hofmeister and Alfred Löhr, Kleine Schriften des Staatsarchivs Bremen 30 (Bremen, 2000), 11-22; Ulrich Weidinger, "Staatsmacht und Diplomatie im Dienst der Glaubensverkündung: Die Nordlandmission der Bremer Kirche im Früh- und Hochmittelalter”, Denkmalpflege in Bremen 16 (2019): 25-48.

2 See Adolf E. Hofmeister, "Bremens Handelsbeziehungen zu Skandinavien im Mittelalter und in der frühen Neuzeit”, Denkmalpflege in Bremen 16 (2019): 50-54.

3 Imsen, "Introduction" (2010), 20-22.

4 Jón Viðar Sigurðsson, "The Norse Community”, in The Norwegian Domination and the Norse World c.1100-c.1400, ed. Steinar Imsen (Trondheim, 2010), 62; Randi Bjørshol Wærdahl, The 
tradition, the Faroes are said to have become a fief of Norway around the middle of the eleventh century; according to Faroese historian Hans Jacob Debes, however, this was a thirteenth-century attempt to legitimise Norwegian rule on the islands, which was in reality not yet established in the eleventh century. ${ }^{5}$ Shetland, which had been ruled by the earls of Orkney, was ceded to King Sverre in 1195 after Earl Harald Maddadson was accused of having supported a rebellion against him. However, in the chronicle Historia Norwegie from the 1160 s or 1170 s, Shetland is already mentioned as paying tribute to the Norwegian king, as are the Faroes. ${ }^{6}$

For Iceland, the situation is clearer. It managed to stay outside the direct control of Norway until the thirteenth century, when a long period of civil war, in which Icelandic vassals of the Norwegian king fought other chieftains on the island, eventually forced the entire island to submit to the Norwegian king. The resulting so-called Gizurarsáttmáli of 1262 and the following 'Old Covenant' (Gamli sáttmáli) of 1302 mark the beginning of Iceland as a skattland of the Norwegian king. From now on, Icelanders had to pay taxes to the king, who in return promised to secure the peace and provided Iceland with a law code. ${ }^{7}$

Another measure included in the Old Covenant was the agreement that every year the king had to provide six ships that would sail between Norway and Iceland. The exact meaning of this clause, which apparently refers to Icelandic foreign trade, has provoked much scholarly debate. The chief impediment to the resolution of this debate is the lack of information about the economic situation in the North Atlantic in the thirteenth and fourteenth centuries. Furthermore, we have to take into account, as Patricia Boulhosa has pointed out, that the text of the Old Covenant is only extant in fifteenth- and sixteenthcentury manuscripts; this has given rise to the presumption that the clause about the six ships might be a later addition. ${ }^{8}$ Scholars have turned to the Icelandic

Incorporation and Integration of the King's Tributary Lands into the Norwegian Realm c. 1195-1397, The Northern World 53 (Leiden, 2011), 70.

5 Hans Jacob Debes, Føroya søga. Skattland og len, vol. 2 (Tórshavn, 1995), 34-35; Bjørshol Wærdahl, Incorporation and Integration, 58.

6 Sigurðsson, "Norse Community”, 62-63; Imsen, "Introduction” (2010), 13-16; Imsen, "Royal Dominion”, 70-73; Bjørshol Wærdahl, Incorporation and Integration, 31, 71-72.

7 Jón Viðar Sigurðsson, “The Making of a 'Skattland': Iceland 1247-1450”, in Rex Insularum. The King of Norway and His 'Skattlands' as a Political System c. 1260-c. 1450, ed. Steinar Imsen (Bergen, 2014), 181-187; Imsen, "Introduction” (2014), 37-38.

8 Patricia Pires Boulhosa, Icelanders and the Kings of Norway: Mediaeval Sagas and Legal Texts (Leiden, 2005); Helgi Porláksson, "King and Commerce. The Foreign Trade of Iceland in Medieval Times and the Impact of Royal Authority", in The Norwegian Domination and the Norse World c.1100-c.1400, ed. Steinar Imsen (Trondheim, 2010), 150-153. 
annals, but these are problematic sources because of their non-systematic and heavily anecdotal character. Boulhosa observes that as a result, any assessment based on them is necessarily tentative. ${ }^{9}$

Nevertheless, it is usually assumed that the thirteenth century saw a decline in the international trade with Iceland, with there being no Icelandic shipowners, possibly due to a lack of timber for the construction of ships. This might have forced the Icelanders into depending on Norway for their foreign imports, hence the clause in the Old Covenant. Archaeological evidence, however, may indicate that there was in fact no cessation in the international trade in the thirteenth century. ${ }^{10}$

Although Iceland in this time might be characterised as economically selfsufficient, this does not mean that there was no foreign interest in Iceland, as Helgi Porláksson notes. There are frequent mentions of Norwegian merchants in Iceland even before the Old Covenant. ${ }^{11}$ For both the Norwegian king and the Icelandic elites, the arrangement about frequent shipping must have been advantageous: for the former, who probably did not maintain his own ships for this purpose, these ships brought the taxes from Iceland. For the Icelandic upper class: the clergy and the chieftains, regular imports from abroad were vital to maintaining their lifestyle and church buildings, though they were at the same time concerned with limiting foreign influence on the island. Moreover, there was a foreign demand for wadmal from Iceland, which was also the currency in which the taxes were paid to Norway. ${ }^{12}$ A similar situation might have been the case in the Faroes, where an arrangement was made in 1270 or 1271 to supply the archipelago from Norway with two ships annually. ${ }^{13}$

However, during the thirteenth to fifteenth centuries, the political attention in the realm gradually shifted southwards. Norway transformed into a landbased kingdom with a political centre in the south, where most of the population lived and where major fortifications were built, from the sea-based power it had been in earlier times. Significant indications of this development are the defeat of Haakon IV's expedition against Scotland in 1263 and the loss of the Isle of Man and the Hebrides to Scotland in 1266, which was the symbolic end of Norwegian dominance on both sides of the North Sea. Moreover, the unification of the Scandinavian kingdoms in the Kalmar Union of 1397 shifted the centre of power even further southwards to Sweden, the Baltic region, and especially

9 Boulhosa, "Fish and Ships", 177-178.

10 Boulhosa, 184-190; Edvardsson, "Commercial and Subsistance Fishing”.

11 Porláksson, “King and Commerce”, 150.

12 Porláksson, 150; Bjørshol Wærdahl, Incorporation and Integration, 39-40.

13 Porláksson, “King and Commerce”, 152; Zachariasen, Føroyar, 161. 
Denmark, where there was a strong influence of German princes. The North Atlantic islands were now on the periphery of the realm. By the beginning of the fifteenth century, North Atlantic islanders had to travel all the way to Copenhagen to see the king, who had all but lost sight of the islands. ${ }^{14}$

Emblematic of this change is the Icelandic aristocrats stating in 1419 at the Althing, Iceland's central political institution, that the agreement about the six ships had not been upheld for a long time, in response to King Eric's prohibition of the island's trade with foreigners. ${ }^{15}$ Indeed, although there were still plenty of ships sailing between Norway and Iceland in the early fourteenth century, the connections were irregular, and the annals show that in many years not a single ship arrived from Norway. ${ }^{16}$ The decline of regular shipping traffic between Norway and Iceland was probably caused by the Black Death in the former country, as the number of ships declined drastically after its onset. ${ }^{17}$ It is against this background that foreign merchants from England, and later Germany, started to appear on the scene around 1400.

\subsection{Bergen and the Hanseatic Kontor}

According to Steinar Imsen, when the focus of political attention in Norway moved southeast during the thirteenth and fourteenth century, the town of Bergen on the western coast of Norway remained a kind of capital city for the skattlands in a fiscal and economic way. ${ }^{18}$ Taxes were paid to the royal governor in the castle of Bergenhus, and trading ships sailed frequently between the city and the islands in the North Atlantic. It is hard to overstate the importance of the city as a commercial and political hub for Norway, the North Sea, and the North Atlantic.

Bergen owed its importance to its strategic location that was both halfway between the rich fishing grounds around the Lofoten archipelago and the European continent and at a reasonable distance from England and the North Atlantic islands (Figure 3.1). It has a good natural harbour, which is closed off

14 Imsen, "Introduction" (2014), 16, 20-26; Imsen, "Introduction" (2010), 21-22; Bjørshol Wærdahl, Incorporation and Integration, 270-271; Baldur Pórhallsson and Porsteinn Kristinsson, "Iceland's External Affairs from 1400 to the Reformation: Anglo-German Economic and Societal Shelter in a Danish Political Vacuum”, Stjórnmál \& Stjórnsýsla 9 (2013): 121, 124-125.

15 DI 4:330; Imsen, "Royal Dominion”, 53; Thomas, Onze IJslandsvaarders, 6.

16 Porláksson, "King and Commerce”, 215; Imsen, "Royal Dominion”, 59.

17 Sigurðsson, “The Making of a 'Skattland”, 215; Porsteinsson, “Island”, 168.

18 Imsen, "Introduction” (2014), 26. 


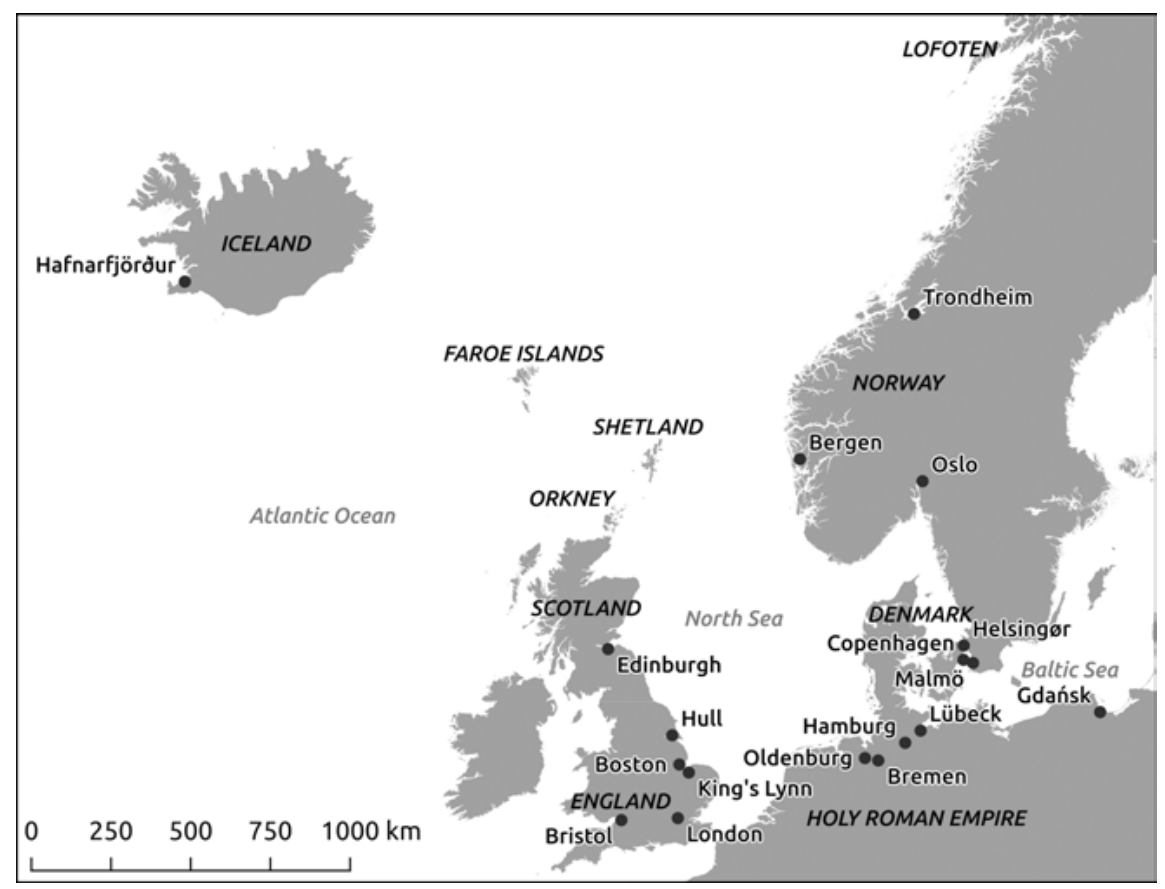

Figure 3.1: Map of the North Atlantic and North Sea region with important locations mentioned in the text.

from the open sea by a large number of islands and skerries. It is therefore not surprising that Bergen rose to prominence during the 11th century, when the Norwegian king asserted his dominance throughout his kingdom and related dominions. On the north side of the bay the castle Bergenhus was built, which in the early centuries was the base of Norwegian royal power. Next to it, a merchant settlement, Bryggen, came into being, which connected northern Norway to the rest of the realm and the British islands. ${ }^{19}$

In the course of the thirteenth century, German merchants began to make use of these trade routes. Previously they had started to defend their common

19 Mike Burkhardt, "Policy, Business, Privacy: Contacts Made by the Merchants of the Hanse Kontor in Bergen in the Late Middle Ages", in Trade, Diplomacy and Cultural Exchange. Continuity and Change in the North Sea Area and the Baltic c. 1350-1750, ed. Hanno Brand (Hilversum, 2005), 136-37; Geir Atle Ersland, "Bergen 1300-1600: A Trading Hub between the North and the Baltic Sea”, in The Routledge Handbook of Maritime Trade around Europe 1300-1600, ed. Wim Blockmans, Michail Krom, and Justyna Wubs-Mrozewicz (New York, 2017), 428-31. 
trading interests abroad, in the process creating a trade network that became known as the Hanse, connecting much of northern Europe in their combined effort to wrest privileges from local rulers. ${ }^{20}$ In Bergen, they appeared in the $1180 \mathrm{~s}$ at the latest. At first the merchants were from Cologne and Westfalia; from the 1240s onwards the majority was from the recently founded trading towns on the Baltic Sea coast such as Rostock, Stralsund, and especially Lübeck, the last of which came to play a leading political role within the Hanse. These cities from the so-called "Wendish quarter" managed to negotiate trading privileges with the Norwegian king for all German-speaking merchants in $1278 .^{21}$

It is crucial to note here, however, that the Hanse should not be seen as a united and static political league. Within the network, cities and merchants often pursued conflicting interests. For the North Sea towns of Bremen and Hamburg, interests in Norway were not always identical to those of the Wendish towns. Bremen, for example, acquired the same privileges as the other Hanseatic towns on its own in 1279, did not take part in the Hanseatic war with Norway in 1284, and sided with Norway in the negotiations for new privileges in $1294 .{ }^{22}$ In 1343 King Magnus instituted new privileges for the Wendish towns and five years later did the same for Bremen. A similarly independent course was charted by Hamburg until c. $1320 .{ }^{23}$ Even though they had joined the other Hanseatic towns by the time the Kontor was established in the 1360s, the conflicting interests of the Baltic and North Sea (and Zuiderzee) towns, due to their different trade networks, provided much of the ground for the disputes regarding the North Atlantic trade later.

Backed by their extensive European trade network, the Hanseatic merchants quickly out-competed the Norwegian merchants in Bergen. They settled in Bryggen (which came to be known as Tyskebryggen, 'the German Dock', Figure 3.2), took over the trade between Norway and the European continent and from c. 1280 that between Norway and Boston, England, as well, which was probably the main market for Norwegian stockfish at the time. By the 1310s the Norwegians had disappeared from the scene, leaving these trade routes to the Germans. The latter established a profitable "triangle trade", importing Baltic grain to Norway, which they sold for Norwegian stockfish. The fish in turn was exchanged for English wool and cloth in Boston, which was then

20 See Dollinger, Die Hanse, 46-47, 59-61, 242-247; on the role of the Hanse in Bergen, see Johan Schreiner, Hanseatene og Norge i det 16. århundrede (Oslo, 1941); Bruns, Bergenfahrer; Nedkvitne, German Hansa; Burkhardt, Bergenhandel; Wubs-Mrozewicz, Traders, Ties and Tensions.

21 Nedkvitne, German Hansa, 33-34, 49-53; Ersland, “Bergen”, 435-437.

22 Hofmeister, “Bremens Handelsbeziehungen”, 55-56.

23 Nedkvitne, German Hansa, 87-89. 


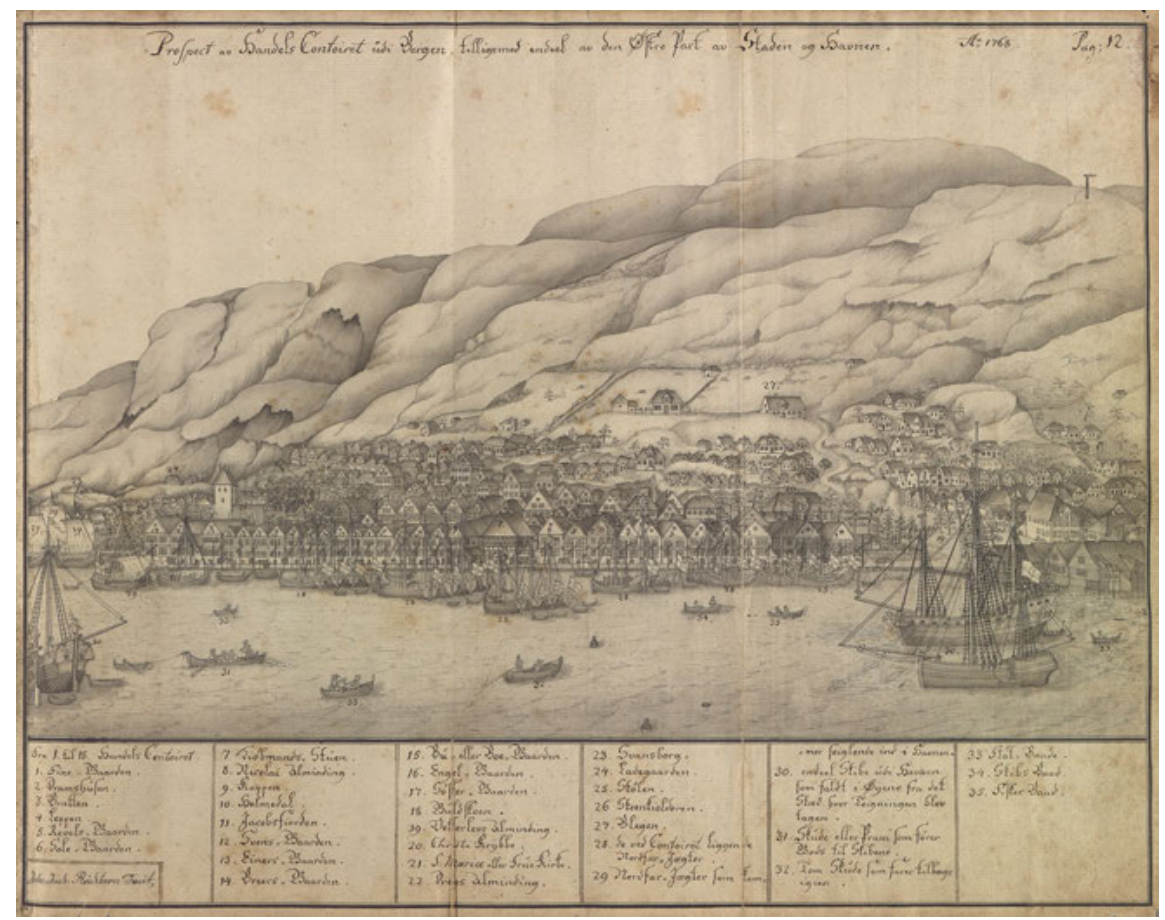

Figure 3.2: Bryggen in Bergen, the site of the Hanseatic Kontor. Drawing by J. J. Reichborn, 1768 , image courtesy of the Bergen Byarkiv.

brought back to the German towns, possibly via Bruges. ${ }^{24}$ English merchants, however, did remain active in Bergen.

The next step taken was the establishment of a Kontor, i.e. a permanent settlement of Hanseatic merchants in Bergen with their own laws and privileges. As early as the 1250s, German merchants had started to stay in Bergen during the winter. As their numbers grew, the Norwegian authorities were confronted with the need to include these residents in their legal system. The merchants for their part started to organise themselves by drawing up their own statutes (willekor), which were for the first time confirmed on a Hanseatic Diet in 1366. These statutes contained detailed rules about the hierarchy and organisation

24 Nedkvitne, 50-53, 79, 91-92; Riis, “Entwicklung”, 34-35; Burkhardt, Bergenhandel, 170-172. 
within the Kontor and for membership, as well as initiation rites for young merchants. ${ }^{25}$ The permanent residents (wintersitzer) controlled the (credit) relations between stockfish producers in the North and the German merchants, and therefore also exercised a large degree of control over the merchants who only visited in summer. With the establishment of the Kontor at Bryggen, Bergen joined Novgorod, London, and Bruges as the most important outposts of the Hanse, albeit being the smallest in terms of trade volume. ${ }^{26}$

The Kontor and the trade with Bergen were dominated by merchants from Lübeck, with merchants from Bremen, Hamburg, and the Zuiderzee towns having a more marginal role. ${ }^{27}$ In the later fifteenth century, however, as the stockfish trade with Boston declined, Lübeck gradually lost its dominant position, opening up the Kontor for merchants from the North Sea towns. As Justyna WubsMrozewicz has shown, merchants from the Zuiderzee region are registered considerably more often as wintersitzer in the late fifteenth century. ${ }^{28}$ However, Bremen merchants became the dominant group in Bergen in the course of the sixteenth century, and would remain so until the abolition of the Kontor in $1764 .^{29}$

For the Norwegian king, the reasons for granting the Hansards privileges in Bergen were on the one hand the importance of Baltic grain imports to Norway, ${ }^{30}$

25 Nedkvitne, German Hansa, 346-351; Burkhardt, “Policy”, 139-141; Ersland, "Bergen”, 437-439.

26 Dollinger, Die Hanse, 124-135; Burkhardt, "Policy", 137; "Die Ordnungen der vier Hansekontore Bergen, Brügge, London und Novgorod", in Das Hansische Kontor zu Bergen und die Lübecker Bergenfahrer. International Workshop Lübeck 2003, ed. Antjekathrin Graßmann, Veröffentlichungen zur Geschichte der Hansestadt Lübeck 41 (Lübeck, 2005), 77.

27 Nedkvitne, German Hansa, 223, 230, 334-442; Wubs-Mrozewicz, Traders, Ties and Tensions, 84-90; Bruns, Bergenfahrer, ix-xxix.

28 Wubs-Mrozewicz, Traders, Ties and Tensions, 116-117.

29 Johan Henrik Schreiner, "Bremerne i Bergen”, Historisk tidsskrift 42 (1963): 291-314; Herbert Föge, "Bremer Bergenfahrt und Bergenfahrer vom 16. - 18. Jahrhundert” (PhD thesis, Christian-Albrechts-Universität Kiel, 1958); Entholt and Beutin, Bremen und Nordeuropa, 11-12; Prange, Kaufmannschaft, 34; Thomas Hill, Die Stadt und ihr Markt: Bremens Umlandsund Außenbeziehungen im Mittelalter (12.-15. Jahrhundert) (Stuttgart, 2004), 200; Burkhardt, Hansische Bergenhandel, 95-96.

30 The extent to which Norway was dependent on imported grain for subsistence is debatable. In the North, the growing of grain was a challenging undertaking, in large part because of the vulnerability to climatic changes, but it was done. A colder period in the thirteenth and fourteenth centuries might have forced Norway to import grain. On the other hand, the emergence of the stockfish production for export in northern Norway to accommodate growing foreign demand meant that people did not have to rely on subsistence agriculture for their survival, and started to concentrate on fishing instead, creating a dependency of foreign grain imports. See Section 2.1.2; Riis, "Entwicklung der norwegischen Wirtschaft", 33; Ersland, "Bergen”, 441; Nedkvitne, German Hansa, 25-29. 
and on the other the wish to protect the Norwegian economy from too much foreign influence. After all, the Hansards had already taken over much of the Norwegian trade with the continent and England. By establishing a staple in Bergen, the king and the nobility could easily partake in the trade and tax it. ${ }^{31}$ In order to protect the staple, the Hanseatic privileges in Bergen from 1294 onwards include a clause that the Hansards were not allowed to trade anywhere in Norway other than Bergen, Oslo, and Tønsberg. In 1302, this prohibition was extended to include the skattlands, i.e. Iceland, the Faroes, Orkney, and Shetland. ${ }^{32}$ Stockfish from the Lofoten, Vesterålen, and the skattlands had to be brought to Bergen by Norwegian merchants called norderfahrer, who sold the fish to the Hansards, who in turn distributed it to England and continental Europe. ${ }^{33}$ Even though there are some indications that some merchants did not adhere to these rules, the members of the Kontor must generally have been inclined to respect the law. After all, the position of Bergen as the staple market for stockfish and their own privileges in the city gave them the possibility of controlling the stockfish trade. ${ }^{34}$

That this position was extremely favourable is illustrated by the fact that the Hanseatic merchants nearly eliminated the English presence in Bergen. During the fourteenth century, they already dominated the trade in stockfish between Norway and England, importing five to six times more stockfish into England than the English themselves did. However, their success did have one drawback. With the disappearance of the English from the stockfish trade between Norway and England, the German trade on that route went into decline as well, virtually disappearing by the 1480s. The reasons for this were the many conflicts between England and the Hanse, which disturbed the trade greatly, and the fact that the English started to look for fish in other areas, and found them in the waters around Iceland. ${ }^{35}$

31 Hammel-Kiesow, “Die Politik des Hansetags”, 191-192.

32 NGL 3:53; HUB 2:18; Nedkvitne, German Hansa, 310; Sigurðsson, "The Making of a 'Skattland'”, 194; Hammel-Kiesow, "Die Politik des Hansetags”, 189-190.

33 Burkhardt, "Policy, Business, Privacy”, 147.

34 Justyna Wubs-Mrozewicz, “'Alle Goede Coepluyden . . . Strategies in the Scandinavian Trade Politics of Amsterdam and Lübeck c.1440-1560”, in The Dynamics of Economic Culture in the North Sea- and Baltic Region, ed. Hanno Brand and Leos Müller (Hilversum, 2007), 88-89.

35 Mike Burkhardt, "One Hundred Years of Thriving Commerce at a Major English Sea Port. The Hanseatic Trade at Boston between 1370 and 1470", in The Dynamics of Economic Culture in the North Sea- and Baltic Region, ed. Hanno Brand and Leos Müller (Hilversum, 2007), 85; Nedkvitne, German Hansa, 184-186; Burkhardt, Hansische Bergenhandel, 172-174. 


\subsection{The English century}

In Icelandic historiography, the fifteenth century has become known as Enska öldin, 'the English century', because the foreign trade with Iceland was dominated by English merchants in this period. ${ }^{36}$ Spurred by German competition in Bergen and the many struggles between the English crown and the Hanse, which unsettled the trade between Bergen and English harbours, English merchants and fishermen started to sail to Iceland to buy stockfish and fish themselves around 1400. Where the stockfish trade had been centred at Boston, it was now mainly merchants from Bristol, East Anglia (King's Lynn), London, and Hull who were active in this trade (Figure 3.1). ${ }^{37}$

It is difficult to assess what exactly led to this English turn to Iceland. Porsteinsson attributes this to a combination of factors, such as technological changes in English shipbuilding, poor fish catches in English waters, and last but not least, the difficult position of the English in Bergen..$^{38}$ Arnved Nedkvitne's statement that the English "changed their defeat in Bergen into a new beginning" ${ }^{39}$ in Iceland goes too far in casting the Hanse as a monolithic power bloc, however. Although the beginning of the English century and the disappearance of the English from Bergen are clearly related, the causality is harder to pin down. It might very well be that the disappearance of the English from the Bergen stockfish trade was caused by the establishment of direct trade with Iceland more than the other way around, as Wendy Childs characterises the English turn to Iceland as "an example of commercial enterprise in cutting out middlemen and maximising profits" ${ }^{40}$ Because the English had lost much of

36 The defining study on this subject is Porsteinsson, Enska öldin; see also Agnarsdóttir, "English Century", 204-205 for a short overview of the historiography.

37 See Eleonora M. Carus-Wilson, “The Iceland Trade”, in Studies in English Trade in the Fifteenth Century, ed. Eileen Power and M. M. Postan (London, 1933), 155-182, 381-383; Porsteinsson, Enska öldin; Bruce E. Gelsinger, Icelandic Enterprise: Commerce and Economy in the Middle Ages (Columbia, SC, 1981); Wendy R. Childs, The Trade and Shipping of Hull, 1300-1500, East Yorkshire Local History Society 43 (Beverley, 1990); Wendy R. Childs, "England's Icelandic Trade in the Fifteenth Century: The Role of Hull”, Northern Seas Yearbook 5 (1995): 11-31; Wendy R. Childs, "The Internal and International Fish Trades of Medieval England and Wales: Control, Conflict and International Trade", in England's Sea Fisheries. The Commercial Sea Fisheries of England and Wales since 1300, ed. David J. Starkey, Chris Reid, and Neil Ashcroft (London, 2000), 32-35; Agnarsdóttir, "English Century”, 204-206.

38 Agnarsdóttir, "English Century”, 205-206; Pórhallsson and Kristinsson, "Iceland’s External Affairs”, 119, 121-122; Porsteinsson, Enska öldin, 24-30.

39 Nedkvitne, German Hansa, 186.

40 Childs, “England's Icelandic Trade”, 12; Pórhallsson and Kristinsson, “External Affairs”, 122. 
their influence in Bergen, the danger of damaging the Bergen staple became a minor issue.

It is equally impossible to pinpoint when the English traders first appeared on the scene. Usually the year 1412 is associated with the first evidence of English traders in Iceland, who were mentioned in the Nýi annáll as having overwintered. As Boulhosa has pointed out, however, this does not mean that they had not been there before, maybe even much earlier. The annal might have recorded the event only because it was deemed extraordinary that the English stayed in winter. The annals do mention foreign merchants in 1392 and 1397, but they might have been Norwegians or maybe even Germans, however. ${ }^{41}$ Moreover, the presence of English fishermen is already attested in $1408 .^{42}$

The arrival of the English in Iceland was beneficial to the Icelanders at first, as they were prepared to pay up to 70 percent more for stockfish than their Norwegian competitors. ${ }^{43}$ Although the Icelanders probably did not invite the English sailings themselves, they must have welcomed the foreigners, as they were quick to ignore the trading bans. The bishops of Skálholt and Hólar, some of whom were English themselves, made active use of English ships, and it is likely that even the Danish-appointed governor traded with the English merchants. ${ }^{44}$ However, English ships came both to trade and to fish, with the latter activity having been more important; it is estimated that more than 100 ships per year were sailing to Iceland. ${ }^{45}$ Fishing in Icelandic waters was not welcomed by the Icelanders, but they tolerated it because the English brought their merchandise and because there was no way to stop them from fishing. ${ }^{46}$ This changed when the Germans started to trade directly with Iceland as well. The Germans are not known to have fished in Iceland at all, concentrating on trading instead, and as such represented an attractive alternative to the English. ${ }^{47}$

41 Boulhosa, "Fish and Ships", 181-183; Porsteinsson, Enska öldin, 24. See also the discussion about the first Hanseatic sailing to the North Atlantic in Section 3.4.1.

42 Porsteinsson, "Island”, 168-169; Agnarsdóttir, "English Century”, 206-208.

43 Agnarsdóttir, “English Century”, 211; Björn Porsteinsson, Tíu Porskastríð 1415-1976 (Reykjavík, 1976), 11.

44 Andras Mortensen, “Økonomisk udvikling på Færøerne i senmiddelalderen”, in De vestnordiske landes fælleshistorie II: udvalg af foredrag holdt på VNH-konferencerne $i$ Ísafjörður 2003, Tórshavn 2004 og Oslo 2005, ed. Andras Mortensen, Alf R. Nielssen, and Jón Th. Thor (Nuuk, 2006), 100; Porsteinsson, Enska öldin, 147-152; Pórhallsson and Kristinsson, "External Affairs", 119; Thomas, IJslandsvaarders, 6.

45 Agnarsdóttir, "English Century", 208.

46 Agnarsdóttir, 214.

47 Pórhallsson and Kristinsson, "External Affairs", 120, 122. 
The Danish king was not happy with the developments in the north, as they undermined the staple of Bergen (and the taxation connected with it), but proved to be rather powerless to do something about it. In part, this must have been because local officials and clergymen were doing good business with the English as well. The English trade with Iceland was prohibited in 1414 and again in 1429, but to no avail. Ships continued sailing north, and eventually the king must have decided to make the best of the situation and issued licences for sailing to Iceland, even if it remained officially prohibited. The licences meant that the king would profit from the illicit trade on the one hand, and secured the position of English merchants in Iceland on the other. ${ }^{48}$

The year 1467 proved to be the turning point in the "English century". An agreement had been made between the Danish and the English king that no English merchant was to travel to Iceland without having first acquired a written licence from the Danish-Norwegian king in 1465. Some English merchants, however, sailed without a licence to Iceland two years later, and came into conflict with the Governor Björn Porleifsson, which led to his murder in Rif. The next year, the Danes captured seven English ships in the Sound as retribution for this act, which drew the Hanse into the conflict as these ships were captured by privateers from Danzig (Gdańsk). In a period of already heightened tensions between the Hanse, Denmark, and England, King Edward IV ordered the seizure of the Steelyard (the Hanseatic Kontor in London) and the arrest of the merchants there. This sparked a war in which Hanseatic privateers and warships, largely from Danzig and Lübeck with some from Hamburg and Bremen, attacked English vessels on the North Sea; trade with England was prohibited by the Baltic Hanseatic towns until $1474 .{ }^{49}$

The conflict between England on the one side and Denmark and the Hanse on the other had significant consequences for commerce across the North Atlantic. On one hand, as Mike Burkhardt writes, the conflict was "the death blow to Lübeck's Bergenfahrer's trade with Boston", ${ }^{0}$ from which it never recovered, and

48 Childs, "England's Icelandic Trade”, 13-14; Agnarsdóttir, "English Century”, 207.

49 Porsteinsson, Enska öldin, 201-222; Porsteinsson, “Island”, 174; Gunnar Karlsson, Iceland’s 1100 Years: The History of a Marginal Society (London, 2000), 121; see also Burkhardt, "Hanseatic Trade at Boston”, 82-83; Dollinger, Die Hanse, 402-408; Stuart Jenks, England, die Hanse und Preußen: Handel und Diplomatie; 1377-1474, vol. 2, Quellen und Darstellungen zur hansischen Geschichte 38 (Cologne, Weimar, Vienna, 1992), 710-736; Terence H. Lloyd, England and the German Hanse, 1157-1611. A Study of Their Trade and Commercial Diplomacy (Cambridge, 1991), 201-214; Kilian Baur, Freunde und Feinde: Niederdeutsche, Dänen und die Hanse im Spätmittelalter (1376-1513), Quellen und Darstellungen zur hansischen Geschichte NF 76 (Vienna, Cologne, Weimar, 2018), 330-331.

50 Burkhardt, "Hanseatic Trade at Boston", 82. 
in more-general terms was exceptionally damaging to the Hanseatic trade with England. More important for the Icelandic trade, however, is that King Christian I of Denmark-Norway for the first time opened the North Atlantic trade to Hanseatic merchants in 1468, making an exception to the restrictions set forth in the Hanseatic privileges in Norway, in an attempt to break the English dominance in Iceland. ${ }^{51}$

Christian's tactic proved to be successful. Hanseatic merchants, who did not have to fear losing their Bergen privileges anymore, established direct trading connections with the North Atlantic islands over the following decade (see the following section). With the Piningsdómur of 1490, named after the governor of Iceland Didrick Pining, the Althing confirmed the rights of German traders as being on a par with the English. ${ }^{52}$ In the same year, King John (Hans) allowed the Hollanders to trade in Iceland, who had been there before as well. If this was done with the same motive as the 1468 granting of permission to German traders, it was less successful, as there is very limited evidence for traders from Holland in Iceland before the seventeenth century. ${ }^{53}$ The importance of the German presence in Iceland as a means to control the stockfish trade with England was underscored by Christian II's prohibition of the German trade with Iceland in 1513, except when the fish were brought directly from Iceland to England. ${ }^{54}$

The following period was characterised by growing competition between the English and German merchants in Iceland, which often ended in violence (Figure 3.3). This was related to the increase in English fishing activity in Iceland between 1490 and 1530, which as we have seen was very controversial among the Icelanders. ${ }^{55}$ As early as 1486 , merchants, skippers, and inhabitants of the English coastal cities complained to the king about the competition from the Germans, who "previously did not use to come [to Iceland], and the English were the only ones trading there, but now no English ship can go there without great danger, peril and adventure, because the Germans support the Danes against the English". ${ }^{56}$ Tensions were heightened by the appointment of the

51 HR II, 6, p. 69; DI 16:220; Porsteinsson, Enska öldin, 222.

52 DI 6:617 (14900701TIN00); Ketilsson, Kongelige Allernaadigste Forordninger, 41-43; Karlsson, Iceland's 1100 Years, 124-125; Ísleifsdóttir-Bickel, Reformation in Island, 128.

53 Baasch, Islandfahrt, 16-17; there are a few mentions of the activities of Holland merchants in Iceland in the fifteenth century; see Thomas, IJslandsvaarders, 7-8.

54 DI 9:357; DN 6:657; HR III, 6, no. 515 (15130812NYK00)

55 Jones, “England's Icelandic Fishery”, 106-107.

56 "Item se hebben nu late upgenomen alle de dait und hanterunge to Bergen in Norwegen und Islant, wor se in vortiiden nicht plegen to komen, sunder de Engelschen deden alle de dait und hanterunge dar, sunder nu mach geiin Engelsch schip dar nicht komen dan up grote sorge, 


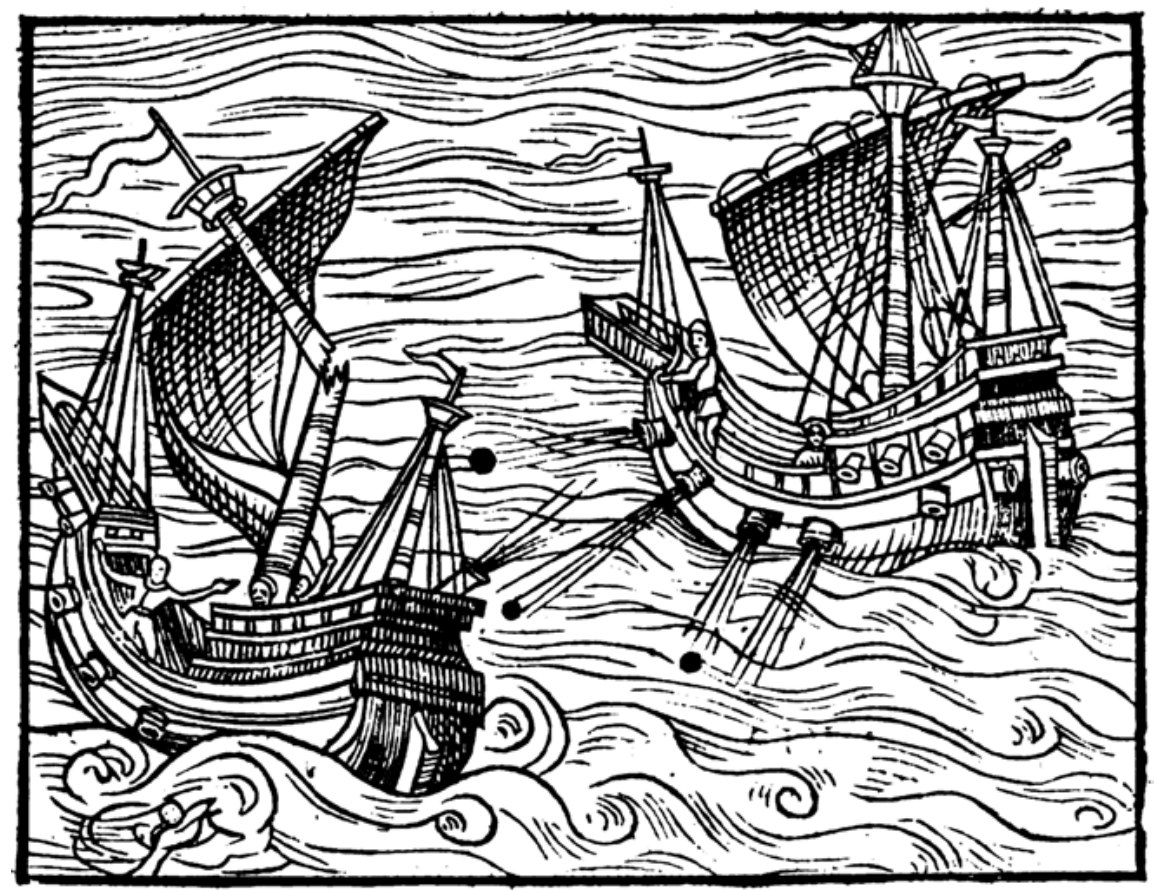

Figure 3.3: Battle at sea between merchant ships in Icelandic waters, from Olaus Magnus, Historia de Gentibus Septentrionalibus (1555).

German-born admiral Didrick Pining as the Danish governor in Iceland, who confiscated English property, to which the English Crown reacted by sending naval support for its fishing fleet in Iceland. ${ }^{57}$ Between 1486 and 1532, Baasch has counted eight instances of conflict between Germans and English merchants in Iceland. ${ }^{58}$ For example, in 1491 during negotiations in Antwerp, the English complained that two ships from Hull had been attacked in Hafnarfjörður by the crew of two German ships, with Pining's support. ${ }^{59}$ On the other side Hamburg merchants complained later that in 1528, skipper Hinrick van Ronne

perikell und eventur, darumb dat de Oisterlinge biistain den Denen tegen de Engelschen, as id is vaken geprovet und bewiiset in des koniinges rait”. HR III, 2, no. 31; DI 11:34.

57 Porsteinsson, Tíu Porskastríð; Karlsson, Iceland's 1100 Years, 124. On Pining, see Section 4.4.1.1.

58 Baasch, Islandfahrt, 21.

59 HR III, 2, no. 511; DI 11:43; see also Baasch, 99. 
had drowned along with 36 others after an English ship had collided with them on purpose. ${ }^{60}$

We would probably not have known about most of these cases, had the conflict not escalated in the summer of 1532. A fight broke out in Básendar between 30 men from a Hamburg ship led by skipper Lutke Schmidt, helped by 80 Germans and Icelanders, and two English ships with 140 men on board. One of the English ships, the Thomas of Hull, was accused of having sunk a German ship three years earlier in Eyjafjörður. The Germans won the fight, after which they beheaded two Englishmen and confiscated a quantity of stockfish. Two months later, conflict erupted in Grindavik, where John Breye from London was trading; he was accused of violence against the Icelanders and of having stolen an amount of stockfish that had been bought by some German merchants in Hafnarfjörður. The Germans, led by bailiff Didrick van Minden, gathered a party of 280 men from eight nearby ships from Hamburg and Bremen and plundered an English ship during the night, killing 15 men on board. The English king Henry VIII reacted furiously and demanded compensation for the damage, and also threatened to revoke the privileges of the German merchants in London. English attempts to gain compensation, however, came to naught due to the close ties between Lübeck and Hamburg and Denmark, cemented by their support for the Danish king Frederick I to gain the throne that same year. Frederick suggested that the English were largely to blame for the situation having gotten out of hand, because they were harming the Icelanders by fishing in their waters without giving them anything in return, whereas the Germans had helped the Icelandic governor by attempting to bring an end to this injustice.

The conflict evolved into a diplomatic crisis and envoy Thomas Lee was sent from London to Hamburg the beginning of the next year to seek a resolution. The Hamburg merchants, however, claiming that they were subjects of the king of Denmark and had only acted on order of the governor, sent Lee on to Denmark. In February 1533, negotiations took place in Segeberg, which accomplished nothing for the English. On the contrary, a document was produced, the Abschied oder Verlaß von Segeberg, which confirmed that the English had brought on the violent course of events by their own behaviour. The document was accepted by Lee, who promised to refrain from repercussions against the Hanseatic merchants in London, and thus avoided further escalation of the matter as had occurred in $1468 .^{61}$

60 SAH 111-1 Islandica, vol. 1a: summary of English attacks on Hamburg ships in Iceland, 1528 (15280000HAM00); Baasch, 99.

61 Reconstruction of these events is mainly based on the large body of documents in SAH 111-1 Islandica, vols. 1a and 1b. Most of these have been published in DI 16:285-337. For a 
Although the rights of both German and English traders were confirmed at the Althing the same year, ${ }^{62}$ these events brought the "English century" to a definitive end. There is little evidence of English trading in Iceland over the remainder of the sixteenth century, and they seem to have limited themselves to fishing, although still on a large scale. They remained active especially around the Vestmannaeyjar, and continued to trade there until 1558, when the islands were given to Simon Surbeck, later mayor of Copenhagen, who managed to drive them out with Scottish help. ${ }^{63}$ However, English merchants never completely disappeared from the scene. In 1552, there are 42-60 English ships - mostly fishing vessels - recorded in Iceland, and 55 in $1593 .{ }^{64}$ In the late sixteenth century, especially in the 1590s, English fishing and trading activity in Iceland increased, ${ }^{65}$ to the point where they got into conflict with the German merchants again. In 1592, Hamburg merchants complained that the English fished so much in the waters around Iceland that there was nothing left for the Icelanders, and that they were hindering German trading ships. ${ }^{66}$ In 1570, Lübeck merchant Luder Ottersen even was summoned before the Privy Council after the English complained that he had been interfering with their trade in Iceland. ${ }^{67}$

\subsection{Direct German trade with the North Atlantic}

\subsubsection{Beginnings before 1468}

When the English turned to Iceland in search of stockfish in the early fifteenth century, Hanseatic merchants were soon to follow. With the slow decline of the trade in Bergen in general and between Bergen and England specifically, they also tried to enter the North Atlantic stockfish market. That they had to infringe

\footnotetext{
narrative in greater detail see Baasch, Islandfahrt, 21-28; Porsteinsson, Tíu Porskastríð; Karlsson, Iceland's 1100 Years, 125-126; Aðils, Monopolhandel, 18-20; Gunnar Karlsson, Lifssjörg Íslendinga frá 10. öld til 16. aldar, Handbók í íslenskri miðaldasögu 3 (Reykjavík, 2009), 304-308; Ísleifsdóttir-Bickel, Reformation in Island, 129-130.

62 DI 16:333B (15330630TINO0)

63 Porsteinsson, “Island”, 187.

64 Porsteinsson, 184.

65 Jones, "Icelandic Fishery”, 107; Agnarsdóttir, “English Century”, 210; on the English fisheries and trade in Iceland from 1580 to 1630, see Helgi Porláksson, Sjórán og siglingar: enskíslensk samskipti 1580-1630 (Reykjavík, 1999).

66 RAK D11, Pakke 26 (Suppl. II, 18a): letter of 10 October 1592 (15921010HAM00).

67 John Roche Dasent, ed., Acts of the Privy Council of England, vol. 7 (London, 1893), 395, 399-400. See also Section 7.2.6.
} 
upon the privileges of their colleagues in Bergen by doing so must have been a relatively small problem for merchants from cities not significantly involved in the Bergen trade at the time, such as Bremen and Hamburg. However, in other Hanseatic cities with a strong involvement in the Bergen trade, such as Lübeck, there were merchants as well who made voyages into the North Atlantic to expand their trade network. ${ }^{68}$

The exact beginning and scope of this early Hanseatic sailing to the North Atlantic are difficult to pin down. This is due to the scarce sources and the problems with their interpretation. Moreover, quite some shaky assumptions have been made with regard to this topic by historians in the past in their urge to trace German presence in the North Atlantic as far back as possible. Notably, they have tried to show that many towns were involved in the North Atlantic trade from an early stage and with a considerable number of ships. Upon closer inspection, however, we find that these claims are based on a quite specific reading of the sources and disregard other possible explanations, and are therefore tentative to say the least. ${ }^{69}$

Generally speaking, two kinds of sources hint at the early presence of German traders in Iceland: annals and prohibitions related to the privileges of Hanseatic traders in Bergen. The problems with the annals have been discussed above, and in relation to the German presence the same conclusions apply as to the English. The Icelandic annals do speak regularly of foreign visitors before the fifteenth century, but without further specification, so that there is no way of knowing whether Norwegians, English, Germans, or others are meant.

For the other sources, often the historian's rule of thumb is applied that if a historical source prohibits an activity, that activity must therefore have taken place. Although this makes sense in general, there are two problems with this assumption with regards to the North Atlantic trade. The first is that it does not tell us anything about the scope of the violations of the rule. The second is that prohibitions to sail to the skattlands are often repeated in new confirmations of

68 Much of this chapter is based on the excellent analysis of the topic of the North Atlantic trade, as it was discussed on the Hanseatic Diets, by Hammel-Kiesow, "Die Politik des Hansetags", which is a revised and extended version of "The North Atlantic Trade with Iceland, Shetland, Orkney and the Faroes and the Policy of the Hanseatic Diet (1369-1535)", in German Trade in the North Atlantic, c. 1400-1700. Interdisciplinary Perspectives, ed. Natascha Mehler, Mark Gardiner, and Endre Elvestad, AmS-Skrifter 27 (Stavanger, 2019), 27-42.

69 Baasch, Islandfahrt, and Friedland, "Shetlandhandel", 66-79, most notably, have put forward many of these assumptions. Their works are still relied upon as the ground-breaking reference works for historians writing about the history of German trade in Iceland and Shetland, respectively. Porsteinsson, "Island", 171-172, presents a more nuanced view, but his article, written in Danish, has largely been disregarded in German historiography. 
the old Hanseatic privileges in Bergen, for example after a change of throne or a conflict. That means that the entire set of rules and regulations was repeated, which therefore does not necessarily point to a violation of any of the prohibitions in particular. Even the original prohibition to sail to the North Atlantic cannot be necessarily considered evidence for Hanseatic commercial activity in that region, as this was intrinsically connected to the establishment of Bergen as a staple port, the very essence of which was not to trade elsewhere. Therefore, if Ernst Baasch writes that the confirmation of Hanseatic privileges in Bergen in 1294 means that the Germans "therefore already at that time practised this trade"70 (i.e. with Iceland), or when Rolf Hammel-Kiesow implies that Hanseatic merchants sailed to the North Atlantic before 1369, based on a letter from the Hanseatic Diet to the Kontor in Bergen which mentions the vørbøden reyse ('forbidden voyage') but does not specify which voyage exactly was forbidden, ${ }^{71}$ or when Arnbjørn Mortensen states that the reiterations of the prohibition to sail to the skattlands in 1302 and 1348 indicate that Hanseatic merchants were active in the Faroes around that time, ${ }^{72}$ we should keep in mind that there is no unequivocal evidence in the written sources to support these statements. Hanseatic merchants might have been in the North Atlantic in the fourteenth century or before, but they might also have not.

Furthermore, clear prohibitions of the North Atlantic trade until 1468 that indicate that it was actually undertaken are hard to interpret as well, and they might have been related to single, not structural, violations of the trading ban. The first of these was in 1416, when the Hanseatic Diet explicitly prohibited direct trade with Orkney, Shetland, and the Faroe Islands in response to complaints by the eldermen of the Bergen Kontor that merchants were engaging in this trade. ${ }^{73}$ Friedland links this prohibition to a 1419 charter, in which the heirs of Heinrich Sparke from Lübeck gave the power to a man in Bergen to reclaim Sparke's outstanding debts with the bishop of Orkney. ${ }^{74}$ Because Sparke can be shown to be still alive in $1414,{ }^{75}$ Friedland concludes that he must have

70 Baasch, Islandfahrt, 4. Baasch's contention is especially questionable, as the prohibition to sail to the skattlands was first included in the Hanseatic privileges in Bergen in 1302 (NGL 3:53; HUB 2:18). Furthermore, he gives no further evidence other than the annals, which do regularly mention foreign traders but do not specify their nationality.

71 HR I, 1, no. 511; NGL 2:346; Hammel-Kiesow, "Die Politik des Hansetags”, 190. The prohibition of the vørbøden reyse was repeated in 1412: HR I, 6, no. $70 \$ 14,15$. Here the text seems to hint at trading in Norway outside Bergen, Oslo, and Tønsberg.

72 Joensen, Mortensen, and Petersen, Føroyar undir fríum handli, 8.

73 HR I, 6, nos. 262, 275, 276; HUB 6:89.

74 HUB 6:255; DN 1:665; Friedland, "Shetlandhandel”, 68.

75 Bruns, Bergenfahrer, 36n4. 
traded with Orkney around $1415 .^{76}$ Next to the uncertain dating (it might also have been written after the Bergen complaints of 1416), the charter does not give us any evidence that Sparke had traded directly with Orkney (or Shetland, which belonged to the diocese of Orkney). Rather, the appointment of an agent in Bergen hints at the possibility that Sparke traded with representatives of the bishop of Orkney in Bergen, which was not against the rules of the Bergen staple.

In 1425, when the Danish king Eric of Pomerania prohibited the trade with northern Norway, Iceland, and the other skattlands explicitly, he remarked that it had started recently. ${ }^{77}$ This remark may be taken quite literally. Although the prohibition is unclear about the specific region in which trade was occurring, an English complaint from 1521 mentions that Hamburg merchants had sailed to Básendar in 1423 and harassed traders from Hull there. ${ }^{78}$ It could be that the king was referring to this specific event, although here, also, the evidence is quite tentative. As Adolf Hofmeister remarks, it is curious that the 1423 event is first mentioned only a century later and is very similar to an English complaint about Hamburg merchants in Iceland from 1491, which also describes an attack of Hamburg merchants on Hull merchants in Básendar that took place in the late 1480 s. $^{79}$

It is curious that the 1425 prohibition was not discussed at a Hanseatic Diet. Between 1416 and 1468, the matter was only discussed once, in 1434/5. The Hanseatic Kontor in Bruges petitioned the diet to repeat its 1416 interdiction of the trade with the tributary lands (without mentioning Iceland). The involvement of the Bruges Kontor might seem remarkable, but as they depended on a staple market as well, a lax general attitude within the Hanse with regard to staple trade would be potentially damaging to their own position in the long run, and thus they took up the matter as a central problem within the Hanse.

76 Friedland, "Shetlandhandel”, 68. Also note Friedland's remark that the order in which the island groups are mentioned in the Hanserecess of 1416 (i.e. Orkney, Shetland, Faroes) "clearly relates to the order in which the Hanseatic merchants penetrated [the North Atlantic]". Although this is - without further evidence - a remark without much factual value to begin with, the connection with the case of Heinrich Sparke undermines the contention even further. After all, there is no evidence that Sparke traded with the Faroes. Rather, the mention of these islands in this context must be seen as part and parcel of the general regulation that Hansards were not supposed to trade with the skattlands directly.

77 "att thennd sedwanne som nyliigt begijnt er off Thijdske och anndre wdlenndske mennd, som icke erre lougliige giftte wdij Norrige, att the haffve seylet och seyle till Helliglannd, Finndtmarckit, Isslannd och annden (stedtz)”. HUB 6:582.

78 HR III, 7, no. 455, §14-15; See Friedland, "Shetlandhandel”, 68n12.

79 Hofmeister, "Schuldbuch 2001”, 28. Cf. HR III, 2, no. 511, §25. 
The diet responded that it would investigate the case and discuss the matter, but no action seems to have been taken afterwards. ${ }^{80}$

A curious aspect of this letter is the fact that it speaks about Vynlande, Orkenoy, and Veroe as the North Atlantic Islands. Vynland is known only from the sagas concerning the Viking explorations in North America, ${ }^{81}$ but that is not likely to have been meant here, and neither is Finland. Other possibilities are that it is a faulty interpretation of Finnmark, a district in northern Norway, and therefore off limits for Hanseatic merchants as well, ${ }^{82}$ or an error of the scribe of the letter, who read Vynlande instead of Hydlande (Shetland) in the text of the 1416 prohibition. ${ }^{83}$ The latter explanation might be the most plausible, as the letter clearly refers to the 1416 prohibition, but it is very likely that the Bruges Kontor was referring to the Icelandic trade as well.

The discussion at the Hanseatic Diet notably coincides with entries in the Danzig Schöffenbuch from 1435 about two journeys to Iceland by the Danzig skipper Peter Dambeke, undertaken in 1432/3 and 1434, which were probably largely unsuccessful, as Dambeke could not find enough fish on the island and had to sail to England instead. ${ }^{84}$ The Bruges Kontor clearly interpreted this as violating the 1416 ban - even if Iceland is not explicitly named there - since in the answer of the gathered envoys at the diet, the matter is treated as "about the matter, that no one shall sail to Iceland etc.”, and the other islands are not even mentioned! $!^{85}$

Another early testimony for the North Atlantic trade is from 1442, when Lübeck merchant Cordt Sten paid Remmert Ulenhot 100 mark to sail to Iceland to look for his brother Henning and to bring him back to Lübeck if he was still alive. ${ }^{86}$ The fact that Sten had to send someone to Iceland specially to look for his brother indicates that regular connections with Iceland had not been established at the time. Also it did not spark debate at a Hanseatic Diet.

Finally, other kinds of documents have been used as evidence of early German presence in the North Atlantic as well, but again these prove to be questionable on closer inspection. For example, Kurt Forstreuter interprets the text of two 1439 documents as being evidence for the involvement of Danzig

80 HR II, 1, no. 393, §12; Hammel-Kiesow, “Die Politik des Hansetags”, 193-195.

81 See Forstreuter, “Hansische Islandfahrt”, 117n2.

82 Forstreuter, 117.

83 Friedland, "Shetlandhandel", 69.

84 DI 5:10-12; HUB 7:81; DN 20:806; see Forstreuter, "Hansische Islandfahrt”; "Nachtrag”, 77-79; Baasch, Islandfahrt, 7.

85 "van deme puncte, dat nemand in Islande seghelen sal etc”. HR II, 2, no. 394, §10.

86 UBL 8:61; Baasch, Islandfahrt, 7; Bei der Wieden, "Lübeckische Islandfahrt”, 12. 
councillor Bertolt Buramer and Johan Hamborch (probably from Lübeck) in the Icelandic trade. ${ }^{87}$ A charter from 17 June by which Olaf Nilsson, the commander of Bergen and governor of Iceland, authorised his servant to Iceland to collect the royal taxes and outstanding debts for himself and Buramer, is interpreted as evidence for the latter's role in collecting the taxes in Iceland. The text of the charter, however, is ambiguous, and it is possible that only the outstanding debts of Buramer in Iceland are meant, which does not have to mean that he traded there directly, especially since the charter was written in Bergen. ${ }^{88}$ Likewise, a note in Lübeck's Niederstadtbuch two days earlier mentions that Johan Hamborch gave Buramer the right to his goods in Iceland. It is likely that Nilsson's servant was ordered to collect these goods in Iceland for Buramer, but once again the text does not permit the conclusion that Hamborch had traded in Iceland directly. ${ }^{89}$ Likely his outstanding debts in Iceland were meant here, for which he might have extended credit to Norwegian or Icelandic merchants visiting Bergen.

There are no further indications for direct German connections with the North Atlantic until 1468. Considering the problematic interpretations of many of these sources, it might do well to stick to Arnved Nedkvitne's conclusion that the prohibition to trade with the skattlands was "violated by individual skippers, [but] the violators must have been few and far between". 90

\subsubsection{The attitude of the Hanseatic Diets}

Generally speaking, Hanseatic merchants must have been inclined to respect the rules set out by the Danish-Norwegian kings in the Hanseatic privileges in Norway, as it safeguarded their control of the stockfish trade in the staple port of Bergen. However, three factors complicated the Hanseatic attitude towards the North Atlantic trade: the changing dynamics of the stockfish trade (especially with England), conflicting interests between merchants from different

87 Forstreuter, “Hansische Islandfahrt”, 118-119.

88 "Vpp at bera mins herra kongsins skatt og skulld epterstaudur ok sakrhræra”. DI 4:626. Probably only the outstanding debts and movable property refer to Buramer. Both Nilsson and Buramer are known to have been in close relation to the Danish king Eric of Pomerania, which might explain why Nilsson assisted Buramer in collecting his debts on the island. Help from local authorities in collecting debts was not unusual in the Bergen trade: see Section 4.2.1; Nedkvitne, Hansa, 408-412.

89 "Dimisit omnia bona que ipse dimisit in Island". AHL, Niederstadtbuch 1430-1451, p. 604; German summary in HUB 7:471.

90 Nedkvitne, German Hansa, 310. 
towns within the Hanse, and the often-changing political circumstances. Therefore, at first glance the protocols (Rezesse) of the Hanseatic Diets in the fifteenth century do not condemn the North Atlantic trade as unanimously as would be expected. ${ }^{91}$ Or to put it in Klaus Friedland's words: "It is hopeless to attempt to build up a clear picture from the statutes and ordinances of the Diet and the Danish crown". ${ }^{92}$

Friedland, however, was not only exaggerating; he is disregarding the internal dynamics of the Hanse. His statement seems to be based on two false assumptions: first, that the Hanse was a unified bloc of cities and merchants in which all had the same interests, and second, that there already existed considerable traffic of Hanseatic merchants with the North Atlantic. If one takes the international political context and the conflicting interests of different towns into account, the picture built up from the statutes and ordinances of the diet and the Danish crown makes more sense, as Rolf Hammel-Kiesow has shown. Generally speaking, this picture is that the North Atlantic trade was condemned if it was prohibited by the Danish crown, and tolerated when it was not (even if it harmed the position of Bergen). The policy of the Danish crown, on the other hand, was highly dependent on other political issues such as those involving the English.

One interesting point is that only the direct trade with Orkney, Shetland, and the Faroes was explicitly prohibited in the diets. ${ }^{93}$ Direct trade with Iceland was never explicitly prohibited in these diets, except for the debatable case in 1434 sketched above. Regular complaints against German merchants for trading directly with Iceland were filed by the Kontor in Bergen, among others, but the diet never managed to produce a clear prohibition of the Icelandic trade, at most stating that the gathered cities promised to refrain from the Icelandic trade. There were two possible reasons for this. First, the Hanse may have wanted to retain their merchants' dominance in the international stockfish trade, which was threatened by the English activities in Iceland. ${ }^{94}$ Representatives of the various cities who came together at the Hanseatic Diets might therefore have been more favourably disposed towards trade with Iceland than with Shetland and the Faroes, where the Hansards experienced less competition from the English. A remark in the Rezess of the Hanseatic Diet in Bremen in 1494 hints at this line of reasoning, as the direct trade with the skattlands was once again prohibited there,

91 For the Hanseatic Diets, see Dollinger, Die Hanse, 116-123.

92 Friedland, "Shetlandhandel", 69; citation translated in Hammel-Kiesow, "North Atlantic Trade", 28.

93 Hammel-Kiesow, "Die Politik des Hansetags”, 190.

94 Hammel-Kiesow, 190. 
"with the exception of Iceland, which is also visited by other nations" 95 (i.e. the English).

It is also quite possible that the frequent prohibition of the trade with Orkney, Shetland, and the Faroes was more a result of the sailings to Iceland than of actual direct trade with these skattlands. After all, there is no unambiguous evidence of direct trade with Orkney, and the first direct evidence for Shetland is only in 1494 (from Bremen), ${ }^{96}$ and for the Faroes in 1486 (from Danzig). ${ }^{97}$ The Bergen Kontor, sensing the diminishing support within the Hanse for upholding the prohibition of the Icelandic trade, might have emphasised the prohibition to sail to Orkney, Shetland, and the Faroes in order to limit the damage done to their privileges. One could even argue that this points at a limited interest of Hanseatic merchants in the Faroes and Shetland, as it was apparently not difficult to make the diet forbid the trade with those places on multiple occasions.

Second, there were the interests of the cities of Bremen and Hamburg in the Hanse in general, and in the stockfish trade in particular. ${ }^{98}$ This proved to be a complicating factor in defining a clear Hanseatic prohibition of the Icelandic trade. As we have seen, due to their differing trade networks, the North Sea towns were less involved in Bergen, and their interests often clashed with those of the cities of the Wendish quarter. ${ }^{99}$ The latter, which were largely dependent on Lübeck, usually supported the faction that voted to uphold the staple trade of Bergen. ${ }^{100}$ The North Atlantic trade of Bremen and Hamburg merchants, who tried to enter into the stockfish trade in the fifteenth century, could therefore very well have been a result of their attempts to circumvent the Lübeck-dominated Bergen Kontor, as Mike Burkhardt proposes. ${ }^{101}$ One should note, however, that the evidence for a Hanseatic presence in the North Atlantic before 1468 does not point towards a specifically high level of involvement of the North Sea cities

95 "Uthgenomen Island, de de fromde natien ok vorsoken". HR III, 3, no. 353 (14940525BRE00). 96 In a letter from the eldermen of the Bergen Kontor to the Hanseatic Diet in Lübeck from 1498: HR III, 4, no. 68.

97 Friedland, "Shetlandhandel", 70-71. Friedland also gives an earlier reference for Danzig (and Hamburg) activity in Shetland in 1487, but this is questionable. His statement is based on HR III, 2 no. 160, in which the representatives of all the cities condemn the trade with Shetland and the Faroes, except for Danzig and Hamburg, who claim not to have had permission of their city councils to decide about this matter. This does not have to mean more than that. Moreover, it could refer to the Faroes only, as in 1486, merchants from Danzig had been accused by members of the Bergen Kontor of having sailed to Iceland and the Faroes (HR III, 2, no. 54).

98 For Bremen, see Hill, Die Stadt und ihr Markt, 337-370.

99 Burkhardt, Hansische Bergenhandel, 67-70.

100 Hammel-Kiesow, "Die Politik des Hansetags”, 193-194.

101 Burkhardt, Hansische Bergenhandel, 93-96. 
in this trade. It is merchants from Hamburg, Lübeck, and Danzig who can be identified as having sailed north, which once again hints at the individual character of these undertakings.

\subsubsection{Conflicting interests within the Hanse after 1468}

The situation changed considerably in 1468. On the one hand, King Christian I allowed the Germans to trade with Iceland after conflicts with the English there, as we have seen. On the other hand, he pawned Orkney and in the following year Shetland to Scotland for the dowry of his daughter Margaret, who married the Scottish king James III. Christian never managed to pay the money, and the Scottish parliament annexed the islands in $1472 .{ }^{102}$ Although Shetland was still linked commercially to Bergen, and trade with the islands still prohibited according to the Kontor's privileges, the loss of direct Danish control over Shetland might have changed the situation for the Hansards. However, it is not until 1498 that we find the first clear evidence for Hanseatic merchants in Shetland, as we have seen.

After 1468, there is ample evidence of openly conducted commercial activity in Iceland by merchants from various Hanseatic towns. ${ }^{103}$ The wreck of Bremen skipper Marten Stene's ship in Shetland, who was on his way to Iceland for a merchant from Braunschweig, is attested in 1469, for example. ${ }^{104}$ The city of Hamburg even actively stimulated trade, testifying to its eagerness to enter into the stockfish trade through the newly opened market. Mentioned in the city's accounts of 1476 are two ships being sent to Iceland: one, the Hispanigerd, partly owned by the city and partly by Dideric Vriensteen, had made the voyage the previous year as well; and the other, the Grote Marie, was completely owned by the city. Freighting space on both ships was rented out to merchants; the stockfish trade on the city's account remained limited. ${ }^{105}$ In 1479 , Casper

102 For the political background of these events, see Barbara E. Crawford, "The Pledging of the Islands in 1469: The Historical Background”, in Shetland and the Outside World 1469-1969, ed. Donald J. Withrington (Oxford, 1983), 32-48.

103 Porsteinsson, "Island", 175.

104 DI 10:26; HUB 9:686, 9:800; Ludwig Hänselmann, "Braunschweiger und Bremer auf der Islandfahrt”, Hansische Geschichtsblätter 17 (1888): 168-172. This is the only evidence for the involvement of merchants from Braunschweig, an inland city, in the Icelandic trade.

105 Karl Koppmann, ed., Kämmereirechnungen der Stadt Hamburg 3: 1471-1500 (Hamburg, 1878), 223, 253; Baasch, Islandfahrt, 8; Christina Deggim, Hafenleben in Mittelalter und Früher Neuzeit: Seehandel und Arbeitsregelungen in Hamburg und Kopenhagen vom 13. bis zum 17. Jahrhundert, Schriften des Deutschen Schiffahrtsmuseums 62 (Hamburg, 2005), 157. 
Weinreich's chronicle of Danzig mentions a ship from that city owned by Ludke Wispendorf that had set sail for Iceland but stranded at the islet Nidingen in the Kattegat. $^{106}$

The Hanseatic presence in Iceland was even discussed openly, but was never controversial during this time. In 1473, during the negotiations in Utrecht that concluded the Anglo-Hanseatic war, the story was brought up of two ships from Holland that had battled with four English ships near Hafnarfjörður two years earlier. Two ships were taken captive by the Dutch, including a German ship that had been captured by the English in Iceland before. They were brought to Amsterdam, and the Germans, apparently from Hamburg, were freed. ${ }^{107}$ The Hanseatic Diet of 1476 in Lübeck, which discussed the treaty, asked the English king to compensate the involved parties, and asked Lübeck to return a ship to the English that they had captured in Iceland in $1475 .^{108}$ Although it thus had become very clear that various towns were active in the Icelandic trade in the 1470 s, this reality did not spur any reaction from the Bergen Kontor.

However, after 1481, when the Norwegian Council of the Realm tried to prohibit the North Atlantic trade again after Christian I's death, it immediately became the subject of discussions at the Hanseatic Diets, as the Council asked the Diet to prohibit the trade as well. ${ }^{109}$ The eldermen of the Bergen Kontor joined in at the Diet in 1482 to complain about the damage being done to Bergen's position by the direct trade with Iceland. The representatives of Hamburg, as the main actor in the direct Icelandic trade, had to withdraw from the negotiations, and the city's merchants had to retreat from the Icelandic trade (with the exception of those ships that had already been prepared for the journey) until the next diet could come to a definite agreement about the matter. ${ }^{110}$ The great number of sources from the 1480s in which the North Atlantic trade is discussed are therefore not necessarily signs of a sudden upsurge in economic activity in the North Atlantic, as Baasch claims, ${ }^{111}$ but should be seen instead against the background of this trading ban.

What followed was a period in which the interests of the cities active in the Iceland trade, Hamburg first and foremost, clashed more and more with those

106 Caspar Weinreich, Caspar Weinreich's Danziger Chronik: ein Beitrag zur Geschichte Danzigs, der Lande Preussen und Polen, des Hansabundes und der Nordischen Reiche, ed. Theodor Hirsch (Vaduz, 1973), 23.

107 HR II, 7, no. 39, §30; DI 11:22; Thomas, IJslandsvaarders, 8-9.

$108 H R$ II, 7, no. 348; DI 12:26.

109 HR III, 1, nos. 350-351; DI 6:362, 6:363; DN 6:589, 3:931.

110 Hammel-Kiesow, “Die Politik des Hansetags”, 196.

111 Baasch, Islandfahrt, 10-11. 
of the Bergen Kontor, while at the same time those same cities tried to come to a consensus at the Hanseatic Diets, which resulted in a "faintly absurd Hanseatic deliberate confusion", as Hammel-Kiesow describes it. ${ }^{112}$ After more than a decade of open commercial activity in the North Atlantic, the position of Bremen and Hamburg in the North Atlantic trade had apparently become so firmly established that it would be much to their disadvantage if they were to prohibit it. ${ }^{113}$ While putting up a show of cooperation, they hid behind one another, attached unrealistic conditions to a possible prohibition, sailed from other harbours so they could claim to not trade with the North Atlantic, or downright ignored trading bans while claiming to uphold them. This led to a number of curious examples of diplomatic statements that seemed to ban the trade but actually maintained the status quo.

In the case of Hamburg, there was another complicating factor: in 1483 riots broke out in the town due to a shortage of grain. Protesters criticised the export of grain to Iceland when there was not enough to feed the own population. ${ }^{114}$ Under pressure from both the population and the Hanseatic Diet, the city council adopted a resolution which banned the Icelandic trade, but left a huge back door open: the ban was only valid "as far as the city area extends, where the council will see that in the city no ship is freighted". ${ }^{115}$ Indeed, during the Diet of the Wendish towns in 1484, Hamburg could honestly state that no ship had left the city for Iceland. The representatives of the Bergen Kontor,

112 Hammel-Kiesow, "The North Atlantic Trade", 32.

113 Signs of the continuing direct trade with Iceland are the frequent mentions of Icelandic fish and sulphur in the Hamburg pound toll register in autumn 1486, at the time of the year when ships returned from Iceland. However, as the registers do not indicate which route these products took, it cannot be excluded that they found their way to Hamburg via Bergen. Hormuth, Jahnke, and Loebert, Pfundgeldlisten, 225-227, 238.

114 HR III, 1, pp. 348-349, n. 6; DI 11:31; Baasch, Islandfahrt, 11-12. These riots were deemed important enough to be included in the Fitjaannáll, one of the Icelandic annals written in the seventeenth century. Between sentences about the birth of Martin Luther is written: "Á pessu ári var mjög mikið upphlaup innbyrðis í Hamborg” ('in this year there were large riots of the citizens in Hamburg'). It is unclear whether the author mentions the matter because of the Icelandic element, since he makes no mention of it. Hannes Porsteinsson and Jón Jóhannesson, eds., Annales Islandici posteriorum sæculorum. Annálar 1400-1800, vol. 2 (Reykjavík, 1922), 25.

115 "ßo verne der stadt ghebede kereth, dar de radth myth dem bestenn wyll vorweßenn, dath in der stadt ghebede nene schepe laden werde”. Johann Christian Lünig, Das Teutsche ReichsArchiv Partis Specialis IV. und letzte Continuation, vol. 13 (Leipzig, 1714), 960; Johann Heinrich Bartels, ed., Nachtrag zum neuen Abdrucke der vier Haupt-Grundgesetze der Hamburgischen Verfassung : Betreffend 1) die älteren Recesse, 2) die Buhrsprache, und 3) Zusätze zu der den vier Haupt-Grundgesetzen vorausgeschickten erläuternden Uebersicht (Hamburg, 1825), 23; Deggim, Hafenleben, 157. 
however, made the charge that Hamburg merchants had loaded a ship destined for Iceland in Wismar. As the gathered representatives of the cities claimed that they had not received instructions about this matter, it was left unresolved, but it was agreed upon that letters be sent to Bremen, Danzig, and other nonWendish cities from which merchants were sailing to Iceland, asking the authorities to put a stop to this. In the letter to Danzig, it was even said that the Norwegian Council of the Realm had threatened to renounce the Hanseatic privileges in Bergen. ${ }^{116}$

Discussion of this issue continued during the diets over the course of the decade (1486, 1487, and 1489). ${ }^{117}$ The arguments brought forth emphasised that the North Atlantic trade harmed Bergen's debt system, as stockfish produced on the islands was now directly transported elsewhere instead of being brought to Bergen, where the stockfish producers still had debts with Bergen's Wintersitzer. This seemed to have been the case mainly for Shetland and the Faroes, however, as it was claimed that Icelandic fish was never brought to Bergen and that the English also traded in Iceland. ${ }^{118}$

During the 1489 Diet of the Wendish quarter the representatives came closest to explicitly prohibiting the Icelandic trade, at least in words, as in practice the wording of the prohibition allowed the trade to go on. The Wendish cities (Rostock, Stralsund, Wismar, Lüneburg, and Lübeck) proclaimed that they would abstain from the Icelandic trade altogether if Hamburg would do likewise. The same should be written to Bremen, not part of the Wendish quarter and therefore note represented at the diet. ${ }^{119}$ Of course, Hamburg had shown six years earlier that it had too much at stake in Iceland, so it would never abandon the trade freely, and the other cities must have known this, which made the ban in fact a tacit acceptance of this situation.

In 1489-90, the Danish crown relaxed its policy towards foreign trade in Iceland. From this point onwards, the Icelandic trade was more or less (but not yet openly) tolerated by the Hanseatic towns, with the frequent complaints from the Bergen Kontor emphasising the unfair competition of the North Atlantic

116 HR III, 1, no. 501 §92-97, no. 510; Hammel-Kiesow, “Die Politik des Hansetags”, 196-197; Friedland, "Lübeck und Island", 160-161.

117 HR III, 2, nos. 31, 54, 160, 164, 269, 270 §28, 30; DI 11:34, 36, 37, 38, 40, 41; DN 5:932 (14870500LUB00).

118 Hammel-Kiesow, "Die Politik des Hansetags", 197; see also Nedkvitne, German Hansa, 400-412; Wubs-Mrozewicz, Traders, Ties and Tensions, 148-152; and Section 4.2.

119 HR III, 2, no. 270, §28, 30; DI 11:41; Hammel-Kiesow, "Die Politik des Hansetags", 197-198. These were the towns with representatives present at the meeting and there was thus the appearance of a unanimous decision. Note that this does not support the conclusion of Baasch, Islandfahrt, 16, that all of these towns were apparently involved in the Icelandic trade. 
merchants in the stockfish trade, instead of that trade being a violation of their privileges. The trade with Shetland and the Faroes was a different matter, although it also proved impossible to prohibit in the long run. In 1494, the Hanseatic Diet in Bremen, at which representatives from all cities known to trade with the North Atlantic were present, resolved to renew the 1416 prohibition to sail to the Faroes and Shetland, but once again did not mention Iceland. Those who sailed to these islands risked losing their rights to Hanseatic privileges and were to be rejected from all Hanseatic towns. ${ }^{120}$ Regardless of these threats, eldermen of the Bergen Kontor complained four years later that Bremen merchants were using the same tricks as Hamburg with regard to the Icelandic trade in 1483, and were fitting out ships to sail to Shetland from ports in Holstein or East Frisia, with consent of the local lords. ${ }^{121}$ Once again, in 1507, representatives from Kampen and Deventer objected to the Shetland stockfish trade, on the basis that rotscher could be acquired very cheaply there, undercutting the position of "good" (i.e. Bergen) rotscher on the Hanseatic markets, suggesting that (Bremen) merchants were still actively trading directly with Shetland. ${ }^{122}$

\subsubsection{The sixteenth century: Gradual Hanseatic acceptance}

At the beginning of the sixteenth century, the Bergen Kontor seems to have been the main opponent of the Icelandic trade, but it was losing support. In 1511 and 1517 the Hanseatic Diet stated that merchants in Iceland should behave peacefully towards the English, without mentioning the illicit character of their presence there. ${ }^{123}$ King Christian II, who realised that he could not stop the North Atlantic trade completely, permitted the Germans to bring Icelandic fish to England but not to Germany during negotiations in Copenhagen in 1513. ${ }^{124}$

Of course, this ban proved impossible to enforce, ${ }^{125}$ and the Bergen Kontor complained in vain in the course of the next years about the North Atlantic trade, this time employing the argument that it was damaging the position of the Hanse and the Kontor. In 1514, the Kontor complained that the North Atlantic

120 HR III, 3, no. $353 \S 85-87$ (14940525BRE00).

121 HR III, 4, no. 68; DI 11:47 (14980405BER00); Hammel-Kiesow, "Die Politik des Hansetags", 198.

122 "Dairover die lude bedrogen worden”. HR III, 9, no. 698 §2; DI 11:57.

123 Hammel-Kiesow, "Die Politik des Hansetags", 198.

124 HR III, 6, no. 515; DI 9:357; DN 6:657 (15130812NYK00).

125 This was repeated in 1515, under threat of loss of privileges and the exclusion from harbours in the realm. $H R$ III, 6, no. 673; DI 8:432; $D N$ 6:659. 
merchants were flooding the market with cheap Icelandic stockfish, ${ }^{126}$ and in 1517 that those who were trading with the North Atlantic damaged the common good. ${ }^{127}$ They received support from the London Steelyard a year later, which stated that the North Atlantic competition with the English and the resulting conflicts were negatively affecting their position in London. ${ }^{128}$ The North Atlantic trade now became an argument in the struggle of the Kontors to survive, as was stated in 1519 by the eldermen from Bergen. They claimed that the Novgorod Kontor had already been abolished, and those of London and Bruges were severely weakened, and the same would happen to Bergen if the North Atlantic trade continued. $^{129}$

The representatives of Bremen and Hamburg, the merchants of which had by this time more or less divided the North Atlantic between themselves, halfheartedly tried to pacify the Bergen Kontor, but refused to end the trade in the north. In 1517, Bremen stated that it would refrain from the North Atlantic trade if merchants of the other towns would do likewise, which of course would never happen. ${ }^{130}$ Whereas the eldermen from Bergen had claimed in 1514 that annually six to ten ships were sailing from Hamburg to Iceland and back, the representatives of Hamburg in 1519 presented their alternative facts: they claimed that only a few ships exported fish from Iceland to England, and a negligible number to Hamburg, and then only if a storm happened to drive them to the Elbe. Moreover, they stated that the city council would be willing to follow the diet's decision, but its citizens would never agree, especially given the fact that the Icelandic trade had already resulted in riots in 1483 (thereby deliberately ignoring the fact that these riots had been directed against the trade with Iceland). As the diet decided that Hamburg should subject its interests to the common good, and only export fish from Iceland to England, even if a ship was driven by storm to the Elbe, Hamburg's representatives answered that they would report this decision to the council, but emphasised that it was unjust to prohibit an activity that had been permitted in 1494 in Bremen. ${ }^{131}$ Of course this was a very liberal interpretation of the 1494 resolution, which had not mentioned Iceland.

126 HR III, 9, no. 737 §3, 4; Bruns, Bergenfahrer, 211-214. See Section 2.1.1.

127 HR III, 7, no. 51.

$128 H R$ III, 7, no. 110 §13, 16; DI 11:66.

129 HR III, 7, no. 154 §10; Hammel-Kiesow, “Die Politik des Hansetags”, 199-200.

130 HR III, 7, no. 39 §165, nos. 190-192.

131 HR III, 7, no. 151 §2, no. 197 §41-43; Hammel-Kiesow, "Die Politik des Hansetags”, 200. 
In October of the same year, a neutral arbiter from Lüneburg was appointed to resolve the conflict. This time Hamburg clearly put its own interests first by stating that its merchants had to make a living somehow and had been treated badly in Bergen (having to pay higher fees to the Kontor than the merchants of other towns) and refused to accept the verdict of the arbiter. They claimed that they would discuss the matter in the city council and send negotiators to Lübeck to respond, but there are no sources which can confirm that this actually happened. ${ }^{132}$ Bremen and Hamburg in the following years would continue to contest any proscription of the transport of Icelandic fish to England only.

In 1524, the Bergen Kontor was not able to convince the Hanseatic cities to prohibit the North Atlantic trade any longer. During negotiations in Copenhagen, a new version of the privileges drafted by Lübeck's Bergen merchants was approved by Lübeck's secretary Paul vam Velde, "with the exception of the Icelandic voyage, which shall be tolerated because of Hamburg, who now has very good relations with the [Danish] royal majesty". ${ }^{133}$ In 1525, this was confirmed by the mayor of Lübeck, who told the Bergen eldermen to accept the Icelandic trade. The 1494 ban on trade with the Faroes and Shetland was reaffirmed in spite of protests from Bremen, which was trying to legalise its Shetland trade, ${ }^{134}$ but this had little effect in practice. By 1535, when Bremen and Hamburg complained about obstruction of their trade with Iceland, the Faroes, and Shetland, the North Atlantic trade had become firmly established. ${ }^{135}$

Later Hanseatic attitudes towards the North Atlantic trade are difficult to reconstruct, due to the fact that the resolutions of the Hanseatic Diets after 1537 have not been edited. However, there is little indication that the North Atlantic trade was ever controversial after that time; discussions were limited to trade in northern Norway instead (which remained prohibited by the Kontor privileges, but was also being disregarded more and more). ${ }^{136}$ The Bergen Kontor had become less influential within the Hanse, Lübeck merchants had become less influential within the Kontor, and the Bergen merchants had become less influential

132 Hammel-Kiesow, 201.

133 "Uthgenamen van der Islandesschen reyse; de sulve scholde stan blyven umbe der Hamburger wyllen, de nu groth gehor hedden by k. w.” HR III, 8, no. $820 \S 92$.

134 HR III, 9, no. 131, §161-163; Hammel-Kiesow, “Die Politik des Hansetags”, 202.

135 HR IV, 2, no. 86; Hammel-Kiesow, 202. The importance of the North Atlantic trade at this time is also indicated by the Bremen customs registers of 1539, which recorded 78,199 pounds of Icelandic fish and 40,400 pounds of Shetland fish, in comparison to 88,134 pounds of unmarked (i.e. probably Norwegian) fish (Witzendorff, “Bremens Handel”, 167). As often with toll registers, however, it is not possible to say which route these commodities took. See also Section 1.1.

136 Hammel-Kiesow, “Die Politik des Hansetags”, 202. 
within the city of Lübeck. ${ }^{137}$ In the course of the sixteenth century, merchants from Bremen became the dominant party in the Kontor, the members of which seem to have accepted that Norway and the North Atlantic had become separate trading regions. ${ }^{138}$ Of course, Lübeck merchants, albeit to a lesser extent, were also active in Iceland, but the demise of Lübeck dominance in Bergen and the gradual acceptance of the North Atlantic trade on the Hanseatic Diets were related phenomena. Whether there is a causal relation, however, is a question that is hard to answer. Rather, these developments should be seen in the light of structural economic and political changes around 1500.

Still, the North Atlantic trade remained officially prohibited under the privileges of the Bergen Kontor. That they never officially sanctioned the North Atlantic trade, even though power relations within the Kontor had shifted, can probably be attributed to their dependence on the Danish-Norwegian king and the importance of the staple of Bergen for their business. In 1545 the Danish king stated that the Hanseatic trade with Iceland, although openly practiced, was officially still prohibited and only tolerated by him. ${ }^{139}$ And Lübeck members of the Bergen Kontor are known to have complained about the direct trade with Iceland as late as 1566 and 1570, stating that Icelandic stockfish should be brought only to England. However, they no longer demanded that the North Atlantic trade be totally abolished. ${ }^{140}$

The merchants active in the North Atlantic trade ignored the official prohibition on a grand scale and profited from the new status quo. The attitude towards this trade reflected in Hamburg's city laws is significant in this respect. Where the Icelandic trade had been officially prohibited after the riots in 1483, just six years later the city council allowed it again, on the condition that all ships should sail from, be freighted in, and return to Hamburg. This regulation was reiterated often and made stricter over the course of the sixteenth century. Penalties were exclusion from the Icelandic trade, confiscation of a part of the commodities, or even loss of citizenship. Moreover, paragraph 51 of the Große Rezess of 1529 stipulated that the trade in England, Bergen, Iceland, and everywhere else should be stimulated for the sake of the city and its inhabitants. ${ }^{141}$

137 Burkhardt, Hansische Bergenhandel, 70.

138 Burkhardt, 96; Entholt and Beutin, Bremen und Nordeuropa, 10-11.

139 DI 11:341 (15450320KOL01).

140 Johann Peter Willebrandt, Hansische chronick: aus beglaubten nachrichten zusammen getragen (Lübeck, 1748), pt. III, p. 115; Baasch, Islandfahrt, 18-19.

141 Deggim, Hafenleben, 157-58; Baasch, Islandfahrt, 37-38. 
In essence, the municipal authorities were trying to make Hamburg a staple market for Icelandic products. ${ }^{142}$

These policies sought to enhance the city's economy and to exclude others from its trade with the North Atlantic. It became prohibited for non-Hamburg ships to be loaded before the citizens' own ships were full, and non-citizens were not allowed to bring their cargo onto a particular ship before citizens had done so. ${ }^{143}$ In 1547, after Iceland had been leased to Copenhagen for ten years (see Section 3.5.2), the Hamburg council reacted by preventing citizens to sail from other towns to Iceland. ${ }^{144}$ Indeed in the same year, Lübeck merchants complained to Hamburg that the city council would not allow to let a ship depart from Lübeck for Iceland with a crew consisting largely of Hamburg citizens; a similar instance is recorded in $1557 .{ }^{145}$ Moreover, in 1579 and 1603, the prohibition to sail from other cities than Hamburg to Iceland was reiterated. ${ }^{146}$

Lübeck and Bremen, which saw their own interests in the North Atlantic threatened by Hamburg's open attempts to establish a monopoly on the North Atlantic trade, regularly tried to counteract this by presenting an argument in favour of Hanseatic cooperation. In 1560, the new Danish king Frederick II revived the Hanseatic privileges in his realm in the Diet of Odense. The resolutions gave more freedom to Danish merchants in Hanseatic towns, among others, and reaffirmed the old Bergen privileges. ${ }^{147}$ When Frederick prohibited the Icelandic sulphur trade a year later, representatives of Lübeck and Hamburg, the merchants of which had been active in this trade, both complained. Where Hamburg emphasised its long tradition in trading in Iceland, Lübeck presented the Hanseatic argument, stating that this prohibition was an attack on the Hanseatic privileges in Danish waters and threatened the welfare of the Hanseatic towns and merchants, even though those privileges had just been confirmed in Odense. ${ }^{148}$ Lübeck, however, conveniently neglected to mention that the Bergen Kontor had always used exactly the same arguments against the North Atlantic trade, and that the Odense resolutions had not mentioned Iceland at all. Moreover, in 1565 burgomaster Bartholomeus Tinappel, who as

142 This went for the Icelandic trade only. Note that the council did prohibit the trade with Trondheim, Stavanger, and Lindesnes in Norway to protect the Kontor in Bergen. Deggim, Hafenleben, 158.

143 Deggim, 157.

144 Deggim, 158.

145 Baasch, Islandfahrt, 39. SAH 111-1 Islandica, vol. 3 (15470408LUB00, 15570320LUB00).

146 Baasch, 47, 52.

147 Baasch, 39; Paul Simson, ed., Danziger Inventar 1531-1891 (München, 1913), 867-870.

148 RAK D11, Pakke 28 (Suppl. II, 22/23): complaint from Lübeck, 28 February 1561 (15610228LUB00). 
councillor of the city had attended the Diet of Odense, acquired a licence for the harbour Dýrafjörður in Iceland, which had been in use by Hamburg before. He could do so because he had served as an admiral of the Danish fleet in the Northern Seven Years' War with Sweden. In so doing he was pursuing his personal mercantile interests at the expense of Hamburg's interests, effectively damaging the Hanseatic common good that Lübeck claimed to uphold. ${ }^{149}$

Thus the argument for the common Hanseatic interest was adopted as a convenient rhetorical trick when a city saw its interests in the North Atlantic threatened by merchants from another Hanseatic city - usually Hamburg. For example, the Bremen merchants who traded in the North Atlantic made appeals to Hanseatic friendship in their complaints to the Hamburg city council, when they feared losing the use of a harbour to Hamburg merchants. ${ }^{150}$

\subsection{Policy of the Danish-Norwegian crown}

\subsubsection{Developments up until the Count's Feud}

As shown above, royal control over the North Atlantic islands was marginal when the English and German merchants established their first direct trading connections in that region in the late fourteenth and fifteenth centuries. This explains that the Danish kings tried to prohibit the trade at first (in 1414, 1425, and 1429), but realised this effort was in vain as they had no real means to control the trade. The English even kidnapped the Danish governor of Iceland in 1425 when he tried to enforce the ban. Eventually, licences for English traders were introduced, even though the trade formally remained prohibited, ${ }^{151}$ and Christian I legalised the trade for German merchants in 1468 after the English had killed the Icelandic governor. Although they had little direct power in the north, the Danish kings had the advantage of having direct control over the Øresund, and used this as a means of pressuring foreign powers. The closing of

149 RAK D11, Pakke 26 (Suppl. II, 16): request for the licence, 11 August 1565 (15650811KOB00); DI 14:289 (15650814КОВ00). See Section 3.5.4.

150 SAH, 111-1 Islandica, vol. 3: complaint from Bremen about Hamburg interference in Berufjörður, 7 April 1579 (15790407BRE00), states for example that "hensische verwandten" should not interfere with each other's business.

151 Pórhallsson and Kristinsson, "Iceland's External Affairs", 124-125. 
the Sound to English ships, as for example in 1468, was quite effective in limiting foreign influence in the skattlands. ${ }^{152}$

The Danish policy also had a strong fiscal dimension: each ship trading with the skattlands was taxed in Bergen (sekkjagjald). ${ }^{153}$ Ships trading directly between the skattlands and the European continent or the British Isles, however, were not. When it became clear that the prohibitions had no effect, the Danish king tried to make the best of a bad bargain: the sale of licences meant that the crown would have income from commercial activity that would otherwise remain untaxed. This was especially urgent in the case of Christian I, who was often in financial difficulty as a result of his acquisition of Schleswig and Holstein in $1460 .{ }^{154}$ In 1463, the sekkjagjald was changed into a harbour tax that was levied in Iceland instead of Bergen. ${ }^{155}$ However, Christian was careful to prevent foreigners to settle in the North Atlantic and establish a permanent presence, as they had done in Bergen. The prohibition for foreign traders to stay in Iceland during the winter is attested from 1480 onwards and was never revoked, regardless of frequent violations. ${ }^{156}$

The opportunistic attitude of Christian I was not popular in Norway, where the Council of the Realm tried to protect the staple of Bergen. Violations of the staple, tolerated by the king, and the giving away of Norwegian skattlands to other potentates, threatened to further marginalise the Norwegian kingdom. It is therefore not surprising that the Norwegian Council of the Realm tried to prohibit the direct foreign trade with Iceland after Christian's death in $1481 .{ }^{157}$ At first this effort seemed to be successful. King John (Hans), Christian's successor, promised in Halmstad in 1483 to prohibit the foreign trade with Iceland, ${ }^{158}$ but he quickly changed his mind. In 1490 he allowed the English to fish and trade in Iceland on the condition that they paid the taxes, and allowed the Hollanders to trade there "just like the Germans". The governor Didrick Pining announced these measures in Iceland upon his arrival that same year, and the Althing that summer approved them. ${ }^{159}$

The resulting document, known after Pining as the Piningsdómur, set out the rights and duties of foreign traders in Iceland for decades, and would remain in

152 Pórhallsson and Kristinsson, 125; Karlsson, Iceland's 1100 Years, 122.

153 Imsen, “Royal Dominion”, 59.

154 See Erik Arup, "Den finansielle side af erhvervelsen af hertugdømmerne 1460-1487”, Historisk tidsskrift 7 (1902): 317-388, 399-489.

155 Karlsson, Lífsbjörg Íslendinga, 270.

156 Oddgeir Stephensen and Jón Sigurðsson, eds., Lovsamling for Island, vol. 1: 1096-1720 (Copenhagen, 1853), 37; Baasch, Islandfahrt, 9.

157 DN 3:931; DI 6:363; HR III, 1, no. 351 (14810912BER00).

158 DI 6:419; DN 13:148; Baasch, Islandfahrt, 16.

159 DI 8:72; DI 6:605; DN 6:609 (14900328KOB00); Pórhallsson and Kristinsson, "Iceland's External Affairs”, 123, 126-127; Baasch, Islandfahrt, 16-17; Karlsson, Iceland’s 1100 Years, 124-125. 
effect until the introduction of the Danish trade monopoly in 1601. It declared that English and Germans should trade peacefully and avoid conflict with one another, and that no foreign merchant could stay in winter, except if he was sick or wounded or his ship was damaged. If a merchant did stay in winter, he was not allowed to sell his goods for a higher price than in summer, to have Icelanders in his service, or to own and use fishing boats. For the Icelanders, it was declared that all who had no livestock of their own were obliged to work for farmers. The latter rule was probably an attempt of the rich Icelandic landowning elite to limit the influence of the foreign trade by preventing poor people to start fishing or trading on their own account. Although the Icelandic administration had little means to enforce the Piningsdómur, and violations of it were frequent, its rules were reiterated many times and never modified during the sixteenth century. ${ }^{160}$

The political turmoil that characterised Danish politics in the 1520s and 1530s proved to be beneficial to the position of the German merchants in the North Atlantic. Baasch is probably right when he characterises this period as "the peak of the Hanseatic Iceland trade". ${ }^{161}$ The German merchants in Iceland were left in peace by the Danish officials, partly because the latter were concerned with political troubles at home, and partly because of the great influence of the cities of Lübeck and Hamburg in Danish politics of the time. It is characteristic that the winter stay - which remained officially prohibited - does seem to have been practised relatively openly in this period. This is probably the nearest the German merchants ever came to establishing a permanent presence in Iceland, culminating in the building of a church in Hafnarfjörður by Hamburg merchants. ${ }^{162}$ Moreover, Germans actively cooperated with local officials, as is shown by the incidents with the English in 1532.

However, it is uncertain if this period was also the peak of German trade in Iceland in an economic sense. Statistical data are absent: there are no indications of trade volumes, and the annual lists of ships in the donation register of the confraternity of St Anne start only in 1532 and are unreliable for the first decade. However, they do give some indication that the number of ships sailing to Iceland from Hamburg was considerably larger in the 1580s and 1590s than ever before (Figure 3.4). At least based on these data, it seems to be an exaggeration

160 DI 6:617; SAH 111-1 Islandica vol. 1a (Low German translation) (14900701TIN00). A modern German translation can be found in Hildegard Bonde, "Die Berichte der isländischen Quellen über Didrik Pining”, Mitteilungen der Islandfreunde 21 (1935): 71-76; see also Karlsson, Iceland's 1100 Years, 124-125.

161 Baasch, Islandfahrt, 31; Bei der Wieden, "Lübeckische Islandfahrt”, 14.

162 Baasch, Islandfahrt, 31, 109-110; Piper, "Die Kirche der Islandfahrer”, 227-232. See Section 5.4.3. 


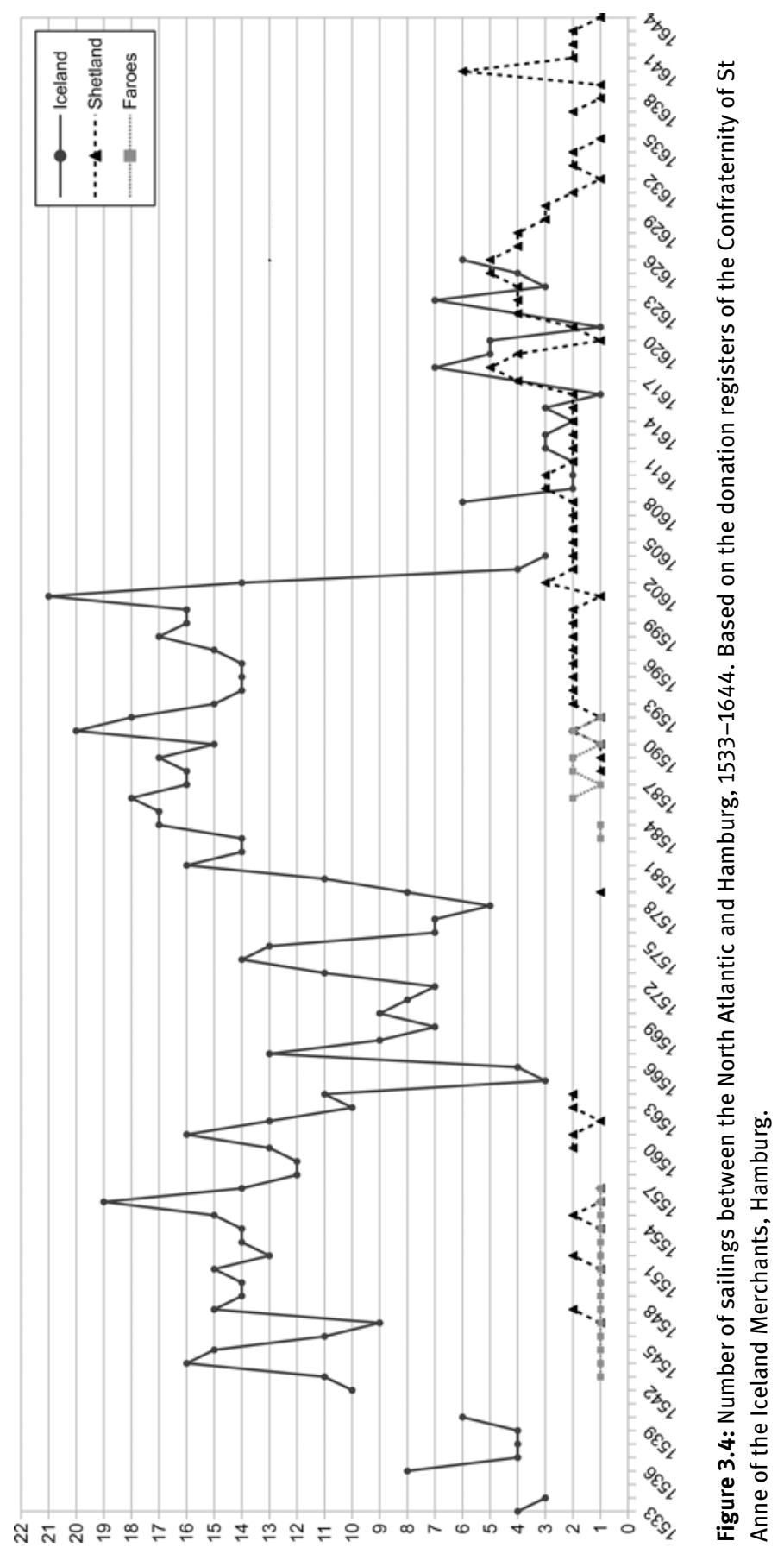


to state that the German presence in Iceland peaked in the 1530s and then entered into a slow decline. ${ }^{163}$

This period started with the ascent of King Christian II to the Danish throne, who ironically tried to limit the North Atlantic trade at first and bring it back under control of Bergen. He must have realised, however, that it was impossible to prevent the direct trade between England and Iceland, and therefore prohibited the Hansards in 1513 to trade in Iceland, unless they brought the fish to England. ${ }^{164}$ Christian's actions, however, were mainly directed against the influence of the Hanse and the nobility in the Danish realm. He seems to have regarded the skattlands merely as sources of income. In 1518, when he was gathering funds for military actions against Sweden, he tried to pawn Iceland to the city of Amsterdam for a loan. The asked-for sum, however, was too high and the deal was declined. ${ }^{165}$ In 1520 , he gave the Faroe Islands to the Hamburg merchant Joachim Wullenwever as a fief, possibly also in return for a loan. ${ }^{166}$ When he had to flee to the Netherlands in 1523, he continued this policy. In an attempt to gather funds for a campaign to reclaim the Danish throne, he once again (unsuccessfully) tried to pawn Iceland and the Faroes for a loan, this time to England in the winter of 1523/4. ${ }^{167}$

Christian's successor Frederick I was supported in his coup by Lübeck and Hamburg, who had been annoyed by Christian's anti-Hanseatic policy. After Frederick succeeded to the throne, Lübeck warships helped to defeat the supporters of Christian in 1524 and were instrumental in capturing him when he tried to conquer Norway in $1532 .{ }^{168}$ The influence of the cities in Denmark was beneficial to both parties: Lübeck received Bornholm and income from Gotland, and Frederick accepted Hamburg presence in Iceland, as the prohibition to sail to Iceland was removed from the privileges of the Kontor in Bergen, as we have seen. ${ }^{169}$ Moreover, Frederick was also supportive of foreign influence

163 Karlsson, Iceland's 1100 Years, 127.

164 DN 6:657; DI 9:357; HR III, 6, no. 515 (15130812NYK00); Alex Wittendorff, Gyldendal og Politikens Danmarkshistorie. 7: På Guds og herskabs nåde : 1500-1600 (Copenhagen, 1989), 76.

165 Thomas, IJslandsvaarders, 10.

166 See Section 3.6.

167 DN 10:382, 412; Evensen, Savn til Føroyinga sögu, no. 11; Zachariasen, Føroyar, 164.

168 Werner Jochmann and Hans-Dieter Loose, Hamburg: Geschichte der Stadt und ihrer Bewohner (Hamburg, 1982), 201-202; Wittendorff, På Guds og herskabs nåde, 93-101; Wolf-Dieter Hauschild, "Frühe Neuzeit und Reformation: Das Ende der Großmachtstellung und die Neuorientierung der Stadtgemeinschaft”, in Lübeckische Geschichte, ed. Antjekathrin Graßmann, 4th ed. (Lübeck, 2008), 383-387, 403-404.

169 HR III, 8, no. 820 §92. See Section 3.4.4. 
on the Faroes, as he gave the islands to his former secretary Thomas Koppen from Hamburg in 1529. ${ }^{170}$ The close connections between the Hanseatic cities and the administration of Frederick I can be seen clearly in the conflict between English and German traders in Iceland in 1532, as discussed above.

Frederick's death triggered the civil war known as the Count's Feud, in which Lübeck sought to extend its privileges in Scandinavia by supporting the Count of Oldenburg, who tried to free the former king Christian. In this struggle, the North Atlantic played a role as well, as the Count of Oldenburg gave the island in Christian's name to the Lübeck general Marx Meyer, who appointed his brother Gerdt as governor. However, Lübeck's strategy backfired: Meyer was captured, much of the occupied land was retaken by the new king Christian III, and Lübeck lost a great deal of its influence in Denmark. ${ }^{171}$ As Helge bei der Wieden has noted, the short-lived enfeoffment of Meyer with Iceland, going against the interests of Lübeck's Bergen traders, was (at least symbolically) the end of the protection of the Bergen Kontor in Lübeck. ${ }^{172}$ Moreover, the end of the Count's Feud in 1536 meant the abolishment of the Norwegian Council of the Realm, which had been the main opponent of the North Atlantic trade and protector of the Bergen staple, along with the Bergen Kontor. ${ }^{173}$

Maybe not surprisingly, shortly afterwards we find the first evidence for direct trade between Lübeck and Iceland since the middle of the fifteenth century, which would remain small but constant during the rest of the sixteenth century. Indeed, it had been so long since Lübeck ships had sailed to Iceland that Hamburg chronicler Bernd Gyseke noted in 1538 "that it has never has been heard of before, that someone from Lübeck sailed to Iceland”. ${ }^{174}$

\subsubsection{The reformation and mercantilism in Iceland}

With the end of the Count's Feud, the consolidation of political power in the hands of Christian III and the introduction of the Reformation in the Danish

170 See Section 3.6.

171 Wittendorff, På Guds og herskabs nåde, 177-190.

172 Bei der Wieden, "Lübeckische Islandfahrt”, 14-15.

173 Hammel-Kiesow, "Politik”, 194, 202n97; Wittendorff, På Guds og herskabs nåde, 215.

174 "Anno 38 int vorjar do reden de van Lubeke erstmals twe scepe in Island, dat vorhen newerle gehort was, dat de Lubeschen in Island segelden. Auerst van den tween quam man een scip in Island vnd van dar hir wedder vp de Elue”. Johann Martin Lappenberg, ed., Hamburgische Chroniken in niedersächsischer Sprache, reprint (Wiesbaden, 1971), 149. See Bei der Wieden, "Lübeckische Islandfahrt”, 14-15; Friedland, “Lübeck und Island”, 158, 163. 
realm, the Danish state embarked on the attempt to impose ever-greater control on its lands, both in a political and economic sense. For the German trade with the skattlands, this is important in two aspects, first the introduction of the Reformation in Iceland and the Faroes, and second the introduction of mercantilist policies in the trade with the skattlands.

It is tempting to assign a significant role to German, and specifically Hamburg, merchants in Iceland in the spread of the Reformation, given their dominant position in European connections with the island. After all, Hamburg, which introduced the Lutheran Church Ordinance in 1529, had developed into a major centre for the spread of the Reformation. These ideas must naturally also have spread to the North Atlantic, as the shipping route with Hamburg was the artery of Icelandic connections with mainland Europe at the time. The church built by Hamburg merchants in Hafnarfjörður in the 1530s probably was the site of the first Lutheran services on Iceland, and it is known from the accounts of the confraternity of St Anne that Hamburg merchants also imported printed books to the island, probably containing religious texts. ${ }^{175}$ Moreover, Bishop Ögmundur Pálsson of the southern diocese of Skálholt complained in 1534 to the bishop of Stavanger that "foreigners" were trying to introduce the new faith in several places. ${ }^{176}$

However, the contribution of German merchants seems to have remained limited to providing the infrastructure for the Reformation in Iceland, which has been characterised as a "revolution from above". A popular Protestant movement does not seem to have existed among Icelanders, except for a small group of clerics in Skálholt, some of whom had studied in Germany. In fact, it was the Danish attempts to take control of the extensive property of the church, and in the process consolidate their political power on the island, which predominantly drove the process of the Reformation. ${ }^{177}$ For their part, Hamburg merchants were concerned that the chaotic situation on the island might damage their trade interests. After all, they were doing a great deal of business with the church, by far the largest landowner in Iceland at the time. After the Danish bailiff in Bessastaðir, Didrick van Minden (the brother of a Hamburg merchant), had taken possession of the monastery of Viðey by force in 1539 and was subsequently killed in Skálholt, the Hamburg merchants wrote a letter to the king in which they asked

175 Ísleifsdóttir-Bickel, Reformation in Island, 135; Karlsson, Iceland's 1100 Years, 128.

176 DI 9:570; Ísleifsdóttir-Bickel, Reformation in Island, 136.

177 Ísleifsdóttir-Bickel, 195; Karlsson, Iceland's 1100 Years, 128-129. 
him to refrain from punitive action, because it would lead to escalation and damage their trade, especially with regards to their outstanding debts. ${ }^{178}$

In the same year, Bishop Ögmundur was replaced in Skálholt by Gizur Einarsson, a Lutheran, who was appointed superintendent by the Danish king. The northern diocese, however, remained Catholic under Bishop Jón Arason, which was tolerated for the time being. This situation would last until 1548, when Bishop Gizur died and Jón Arason attempted to take control of Iceland and to return it to the old faith by taking Gizur's successor Marteinn Einarsson prisoner. His plan to remove the last elements of resistance to his rule backfired, however, and Jón was himself taken prisoner and beheaded in 1550. Christian III sent warships the next year to restore order on the island and to appropriate monastic property. This action made him the second-largest landowner on Iceland, firming up his control over the island. ${ }^{179}$

Christian also accused the Hamburg merchants of having supported Jón Arason against the Danish crown. ${ }^{180}$ Although this might seem like an odd alliance, and the role of the Hamburg merchants in this is unclear, it is not completely unlikely. The accusation should be seen against the background of the other means by which the Danish king tried to bring Iceland under his control, which was by mercantilist measures. Economic developments in Europe, especially the rising demand for and prices of grain, on which the Danish economy relied heavily, combined with the relative stability of Danish politics after the civil war, provided the Danish crown with the means to impose ever-greater control of and stimulate economic activity throughout the realm. The increase in English, Dutch, and Hanseatic shipping through the Øresund, while the land route between Hamburg and Lübeck lost importance, greatly boosted the income flowing into the royal treasury, especially after the Sound Toll was changed to a tax on a ship's cargo in 1567. Connected to this was the growing prominence of the city of Copenhagen, with its merchant class of Danish and German descent, in the export of highly sought-after Danish grain to Western Europe and other parts of the Danish realm. All this put the kingdom of Denmark in a central position on the economic and political map of Europe. ${ }^{181}$

178 DI 10:224, 225 (15400116HAM00, 15400118HAM00); Ísleifsdóttir-Bickel, Reformation, 186-196. 179 Karlsson, Iceland's 1100 Years, 132-133.

180 DI 12:98: “oc same biscop haffuer vdj mange andre maade skickett sig wtilbørligen oc som en whørsom vndersotte, huilcket wij forsee oss till att hand icke giortt hagde, ther som thett icke haffde weritt the Hamborger tilskyndelsz". Porsteinsson, "Island”, 186; Baasch, Islandfahrt, 35; Thomas, IJslandsvaarders, 12-13; Îsleifsdóttir-Bickel, Reformation in Island, 264.

181 Jochmann and Loose, Hamburg, 204; Albert Olsen, "Nogle Synspunkter for dansk merkantilistisk Erhvervspolitik”, Scandia 3 (1930): 226-229; Ole Feldbæk, Danmarks økonomiske historie 
The first attempts to take greater control over the North Atlantic trade were small but significant. In the 1540s Christian III took steps to make the foreign merchants in Iceland respect the rules set out in the Piningsdómur again. The prohibition against the winter stay was reiterated in 1542, at the Althing in 1545, and once again in $1548{ }^{182}$ In 1544 governor Otto Stigsen confiscated fishing boats from Hamburg merchants on Iceland, because foreigners were not allowed to have them. Hamburg protested loudly against this action, and sent a delegation led by merchant Lutke Schmidt (who had played a significant role in the English-German conflict in Iceland in 1532) and jurist Adam Scheidewint to Kolding to discuss the matter before the Danish Council of the Realm in March 1545. Hamburg claimed that they were doing the Icelanders a favour by providing them boats to fish that they otherwise would not have been able to acquire. Stigsen responded with a long list of complaints against the Hamburg merchants, who were accused of violating the ban on the winter stay, intimidating the locals, using their own weights and measures, and taking the law into their own hands at the trading sites. Also, he subtly reminded the Hamburg merchants that officially the entire North Atlantic trade was still prohibited, and that they were only tolerated through the king's "special favour and will". ${ }^{183}$ The council decided in his favour, showing the Hamburg merchants for the first time in several decades that there was a limit to their influence on the island. ${ }^{184}$

The next step came in 1547, when Christian III attempted to lease the entire island to the city of Copenhagen for ten years against a fixed annual payment of 1000 Lübeck mark for three or four years. In return, the city would receive all revenues in taxes and penalties. The lease required the city to provide commodities to the inhabitants and to appoint a governor, who would stay on the island the entire year. ${ }^{185}$ The action was clearly intended to counter the dominance of foreigners on Iceland, and the governor, Lorentz Mule, quickly came into conflict with the Hamburg and Lübeck traders in Iceland. The main issue was the enforcement of the prohibition of the winter stay. In December 1549 Mule arrested five merchant apprentices (kaufgeseelen) from Lübeck and Hamburg

1500-1840 (Herning, 1993), 28-29, 45-51; Wittendorff, På Guds og herskabs nåde, 15-18, 231-237, 283-288; For the Sound Toll, see Ole Degn, Tolden i Sundet: toldopkrævning, politik og skibsfart $i$ Øresund 1429-1857 (Copenhagen, 2010).

182 DI 11:367 (15450630TIN00); DI 11:576; Baasch, Islandfahrt, 33.

183 "Das kon. Maist. landt Eijslandt, der Cronen Dennemarck frey schatzlandt, das keinem kauffmann zu besigeln geburt, Es geschee dann mit kon. Mayst. sunderlicher gunst vnnd willen”. DI 11:341 (15450320KOL01).

184 DI 11:340-343 (15450320KOLO0, 15450320KOL01, 15450320KOL02, 15450320KOL03); Baasch, Islandfahrt, 33, 60-61.

185 DI 11:477 (15470104KOL00). 
because they were staying in Iceland in winter. He brought them to Amsterdam, where they managed to escape custody. Angered, Christian wrote to Hamburg and Lübeck about this, requesting that the young merchants in question be punished accordingly. ${ }^{186}$

Hamburg and Lübeck sent a delegation to discuss the matter in Denmark, which defended the presence of the junior merchants on the island halfheartedly by stating that Mule had more or less forced them to stay in winter. He had prohibited the Icelanders from trading with them, so they had not sold their goods and had to leave them on the island with someone to guard them. This was juxtaposed with the good service that the foreign merchants provided to the Icelanders, who were saved "from dangerous famine by the Hamburg merchants" 187 by selling them food and other commodities. Furthermore, the merchants supplied the Icelanders with fishing boats, enabling them to earn income and making them less dependent on the rich landowners ("die reichen hausbunde"), who were therefore supporting the governor's actions against them (the merchants). ${ }^{188}$ The king was not impressed by this line of reasoning, and emphasised that the winter stay had been forbidden since the Piningsdomur in 1490 and that the Germans were free to leave their goods on the island, where the Icelanders could safeguard them. ${ }^{189}$ This situation was confirmed at the Althing in 1550, where the old conditions of the German trade with Iceland were reiterated, although it was also decided that Lorentz Mule should give the confiscated goods back to the Germans. ${ }^{190}$

The situation escalated in the same summer in which bishop Jón Arason was murdered. Hamburg merchants and sailors kidnapped and mistreated the bailiff Christian Skriver and stole a load of stockfish from traders from Copenhagen. ${ }^{191}$ In the charges against Jón Arason, it was stated that he had promised the Hamburg merchants that he would get rid of the Danes for them. ${ }^{192}$ Although the role of Hamburg merchants in these developments is unclear, it is not unlikely that they cooperated with bishop Jón, as both were in conflict with the Danes, who were trying to impose their control on Iceland.

186 DI 11:627 (15491220NYB00); Baasch, Islandfahrt, 33-34; Thomas, IJslandsvaarders, 13; Bei der Wieden, "Lübeckische Islandfahrt”, 17.

187 "von gefharlichen hungersnoten durch die Hamburgische khauffleuth". DI 11:644 (15500000HAM00).

188 DI 11:644 (15500000HAM00).

189 DI 11:645.

190 DI 11:658 (15500630TIN00).

191 Porláksson, Frá kirkjuvaldi til ríkisvalds, 36.

192 DI 11:678, p. 817; Porsteinsson, "Island”, 186. 
When the Danish king threatened to send warships to Iceland to act against the Hamburg vessels there, Hamburg had to step back, and negotiations were arranged to take place in Flensburg in March 1551. The Hamburg representatives came with a long list of grievances about the Danes. It was claimed that they were clearly disadvantaged against the Copenhagen merchants, who were allowed to stay in winter, even though they had only been sailing there for a few years and in small numbers (two ships per year), whereas Hamburg merchants had been sailing there for over 200 years in large numbers (18 ships per year). Clearly the number of years was a gross exaggeration, but they had made their point, refuting the argument put forth by councillor Andres von Barby that the Copenhagen presence was based on old privileges. ${ }^{193}$ In the end, it was agreed that Hamburg had to pay 2,300 daler in compensation and Copenhagen had to give back the confiscated goods. Moreover, the king must have realised that the Hamburg merchants' position on the island was still too strong and that Copenhagen merchants were not yet in a position to replace them, given the fact that the situation had gotten so out of hand during the time the island was licensed to the latter. In 1552 Christian ended Copenhagen's control over Iceland after only four years, although the latter were allowed to retain the Vestmannaeyjar. ${ }^{194}$

\subsubsection{The 1561 sulphur monopoly}

After 1560 the situation changed rapidly. Had Christian III already attempted to impose greater control on the North Atlantic trade, with Frederick II's ascent to the throne in 1559 the mercantilist tendencies became firmly established. Aware that he could not establish full Danish control overnight, Frederick took a more gradual approach, though he did start to introduce limitations on the North Atlantic trade almost immediately after the change of throne. These limitations first and foremost affected Hamburg, which had the strongest position in the north and had the greatest economic power as a growing staple market for northern Europe. For Frederick, a limitation of the position of Hamburg would benefit the Danish economic and political power. Moreover, he found out that he could

193 SAH 111-1 Islandica, vol. 2: "Relation” March 1551 (15510300HAM00); Baasch, Islandfahrt, $35-36$.

194 On the lease of Iceland to Copenhagen, see Porsteinsson, "Island”, 185-187; Aðils, Monopolhandel, 31-42; Karlsson, Iceland's 1100 Years, 138; Porláksson, Frá kirkjuvaldi til ríkisvalds, 36-37; Baasch, Islandfahrt, 37. See Section 6.1. 
use the North Atlantic trade as a lever to demand loans and payments from cities, and to play them out against each other.

The early years of the 1560s saw a succession of restrictions imposed on the North Atlantic trade. The first of these was the prohibition of the sulphur trade for foreigners. As Iceland was one of the few areas in Europe with natural occurrences of sulphur, which was of high necessity in warfare as an essential ingredient of gunpowder, it is not difficult to imagine how strict royal control of the sulphur trade was a benefit. The rising tensions with Sweden, which would eventually lead to war in 1563, made greater control over the sulphur trade even more desirable. As soon as Hamburg's city council learned of Frederick's plan, a delegation was sent to the king to dissuade him from executing it, but to no avail. ${ }^{195}$ On 19 January 1561, Frederick wrote to governor Paul Stigsen and commander Magnus Gyldenstern that merchants from Bremen, Hamburg, and Lübeck were not allowed to trade in sulphur any more. ${ }^{196}$

A monopoly on this trade was instead given to Stefan Loitz from Stettin and his family, with a term of twelve years and an annual fee of 3,000 Rhenish guilders. ${ }^{197}$ The Loitz family would charter other merchants to sail for them to Iceland and bring the sulphur to Copenhagen, where the king had commanded admiral Herluf Trolle to construct a building with two mills for refining sulphur in 1562. ${ }^{198}$ Also, the king himself sent two ships of 100 lasts to northern Iceland to collect sulphur. ${ }^{199}$ As the refining of sulphur requires a great deal of train oil to remove impurities from the material, in 1562 Frederick also announced to his Icelandic subjects that he would buy all train oil they produced and they were no longer allowed to sell it to foreigners. ${ }^{200}$

Granting the sulphur monopoly to the Loitz family was a very strategic move. The family, based in Stettin and Danzig, ran one of the most important trading houses in northern Europe in the mid-sixteenth century, and had among others established a near dominance of the salt trade in the Hanseatic network through business deals and marriages. They had amassed an enormous amount of capital as well, which they invested by serving as bankers for the nobility. ${ }^{201}$ Frederick II

195 Baasch, Islandfahrt, 40; SAH 111-1 Kämmerei, vol. 3b, pars 3 (1543-1562).

196 DI 13:426, 427 (15610119EMB00, 15610119EMB01).

197 RAK D11, Pakke 30 (Suppl. II, 35): monopoly of 28 June 1561 (15610628KOB00).

198 Mehler, "Sulphur Trade", 194-195.

199 DI 15:521.

200 "all thend lyse oc traunn, ther er paa wort lannd Islannd at bekomme". DI 13:531; Mehler, "Sulphur Trade", 196.

201 Despite the prominence of the Loitz family in their time, they have received remarkably little attention in historical research. Johannes Papritz, in Das Stettiner Handelshaus der Loitz im Boisalzhandel des Odergebietes unter besonderer Berücksichtigung seiner Beziehungen zum 
had a number of reasons for strengthening his ties with this family; by giving them the Icelandic sulphur monopoly, for example, he gained access to their capital, which he needed for waging war against Sweden. When war broke out in 1563, Stefan Loitz also supplied the Danish king with arms and munitions and with intelligence gathered by his widely branching family network. ${ }^{202}$

That said, one of the main reasons for the Loitz monopoly was to break Hamburg's dominance in Iceland, which Stefan Loitz found out soon enough after he tried to charter Hamburg ships to sail to Iceland to fetch sulphur for him in 1562. Two ships were fitted out by his Hamburg factor, and when news of this reached the king, he subsequently denied permission for one ship of 80 lasts under command of skipper Peter Klott to sail out. In addition, 40 to 50 lasts of sulphur from another ship that had returned from Iceland to Hamburg were confiscated, because the cargo had not been brought to Copenhagen. The skipper Hans Schomaker claimed that he had been forced by severe weather conditions to sail back to Hamburg instead of going to Copenhagen. ${ }^{203}$ Whether this was true or not (bad weather was a popular argument to justify one's presence where one was not supposed to go), Stefan Loitz refused to pay the 3,000 guilders he was due, claiming that the king himself had sent two sulphur ships to Iceland as well, thereby violating the conditions set out in the monopoly contract. $^{204}$ King Frederick was not happy with this, especially after Stefan's brothers Simon, Hans (III) the Elder and nephew Hans (IV) the Younger interfered in the matter. After negotiations by Stefan's servant Marcus Heine in September 1563, the monopoly was renewed with different conditions. The king and Stefan Loitz would form a company with a term of seven years that would send two royal ships to Iceland annually, for which Stefan Loitz would supply the commodities and earn the profit. In return the Loitz family would

brandenburgischen Kurhause (Berlin, 1932) and "Das Handelshaus der Loitz zu Stettin: Danzig und Lüneburg”, Baltische Studien NF 44 (1957): 73-94, focuses mainly on their role in the salt trade. Their involvement in the sulphur trade and their relations with the Danish court have largely been ignored. For the historiography of the Loitz family, see Heidelore Böcker, "Das Handelshaus Loitz. Urteil der Zeitgenossen -Stand der Forschung -Ergänzungen”, in Akteure und Gegner der Hanse - Zur Prosopographie der Hansezeit, ed. Detlef Kattinger, Ralf-Gunnar Werlich, and Horst Wernicke, Hansische Studien 9 (Weimar, 1998), 203-218.

202 RAK D11, Pakke 30 (Suppl. II, 35): letters from Stefan Loitz to the Danish court, 1561-1567; Papritz, "Das Handelshaus der Loitz”, 88.

203 RAK D11, Pakke 26 (Suppl. II, 18a): letters from Hamburg to King Fredrick II, 1562, 14 April (15620414HAM00), 30 May (15620530HAM00), and 17 October (15621017HAM00).

204 RAK D11, Pakke 30 (Suppl. II, 35): letters of Stefan Loitz to the King, 1562-1563 (15621212STE00, 15630224STE00, 15630522ANNO0). 
loan the king 60,000 daler with a term of for three years. Moreover, the confiscated Hamburg sulphur would be returned to them. ${ }^{205}$

The relation between the Danish King and the Loitz family was never a happy one, though, and it is likely that the latter did not fulfil their contractual obligations for the full seven-year term. It is very likely their trade in Icelandic sulphur came to a halt when they came into conflict with the king again in 1568, after which they lost their royal support and had to pay double toll amounts for their ships with sea salt in the Sound. This was one of the major factors that led to their bankruptcy in 1572, which took with them many members of the high nobility who were indebted to them. ${ }^{206}$

Of course Hamburg merchants, who had been very active in the sulphur trade in the north of Iceland in the years before, were severely affected by this. Delegations were sent to the king again in 1562 and 1563. Hamburg claimed to have sent two or three ships annually to northern Iceland, where most of the sulphur was mined, and invoked the divine order of the world, according to which no country had the right to deny others the opportunity to import and export goods. ${ }^{207}$ This appeal for mercy not surprisingly fell on deaf ears, and Hamburg merchants tried in vain to find other ways to remain active in this profitable trade. $^{208}$ In addition to sailing on the order of Stefan Loitz, Hamburg merchants probably sailed illegally to Iceland for sulphur. ${ }^{209}$ In 1561, Claus Rode from Lübeck confessed that he had seen Hans Rolfs and Henning Struckman buy sulphur and load it on a ship in Iceland. ${ }^{210}$ In 1563 , before the start of the sailing season, Hamburg petitioned the Danish king to permit its merchants to sail to northern Iceland in order to reclaim their still-outstanding debts in sulphur. ${ }^{211}$ The answer

205 DI 14:133; Ketilsson, Kongelige Allernaadigste Forordninger, 26-28. (15630929KOB00); RAK D11, Pakke 30 (Suppl. II, 35): complaint by Simon Loitz and Hans Loitz the Elder and Younger, 24 February 1563 (15630224STE00).

206 Papritz, "Das Handelshaus der Loitz”, 83, 86-87; Bei der Wieden, "Lübeckische Islandfahrt”, 20.

207 SAH 111-1 Islandica, vol. 3 (15610306HAM00); Baasch, Islandfahrt, 40.

208 Baasch, 79, based on a note on the Carta Marina from 1539 that one pound of sulphur cost $1 / 2$ ducate, and on the sale prices in the account books of the confraternity of St Anne in Hamburg, calculates that the profit margin of the sulphur trade was 1600 percent. This was gross profit, of course, as the costs for transportation and organisation, tolls, hire for the crew, etc. had not yet been subtracted.

209 There are some mentions of illegal sulphur smuggling from the 1560s; see Mehler, "Sulphur", 199.

210 RAK D11, Pakke 26 (“Fundes i Suppl. II, 16-17”): testimony from 22 November 1561 (15611122NYB00).

211 RAK D11, Pakke 26 (Supplement II, 18a): request of 16 April 1563 (15630416HAM00). 
of the king to this latter request is not known, but it was unlikely that he would have given them permission to sail north an additional year, and the sulphur ban was never revoked. ${ }^{212}$

On the contrary, Frederick II moved to limit trade by foreigners in Iceland even more. In March 1563, he also prohibited the sale of horses, fox and bear skins, and walrus and whale teeth to foreigners before they had been offered to the Danish officials on the island. ${ }^{213}$ This measure had probably been provoked by the sale of a "unicorn horn" to Hamburg merchant Cordt Blome in 1561, as has been discussed above. ${ }^{214}$

\subsubsection{The licence trade in Iceland}

Next to restricting the trade in certain Icelandic commodities, Frederick tried to limit the access of German merchants to certain harbours through the introduction of licences (Figure 3.5). Some preliminary attempts had already been made to bind merchants to a certain harbour, as it had been ordained in 1545 that a ship was only allowed to trade in one harbour (i.e. the harbour for which they had paid taxes). ${ }^{215}$ From the early 1560s onwards, merchants would have to apply for a licence in order to trade in a specific harbour in Iceland. Initially, the licences were valid for an unspecified number of years, but in the last decades of the sixteenth century the term of the licences was shortened to just a few years. This would provide the merchants the security that they were the only rightful traders in a certain harbour - something that previously had been governed by tradition and custom, but which left merchants without means to act against the interference of competitors in their harbours - but also a lot of insecurity. After all, a licence could be given to someone else after it expired or at any other moment if the king decided to do so. It is unclear whether this caused more competition between different merchants and their companies, but at least from this point on conflicts produced written evidence, providing us with insight in the workings of the North Atlantic trade.

According to an agreement between Hamburg and the Danish king of 24 November 1585, licences were introduced in an agreement between both

212 See also Section 6.5.

213 Ketilsson, Kongelige Forordninger, 1776, 2:18-20; Baasch, Islandfahrt, 42.

214 See Section 2.5.

215 “puiat eigi skal eitt skip hafa kaupskap meir enn j eirne höfn.”; DI 11:367 (15450630TINO0). 


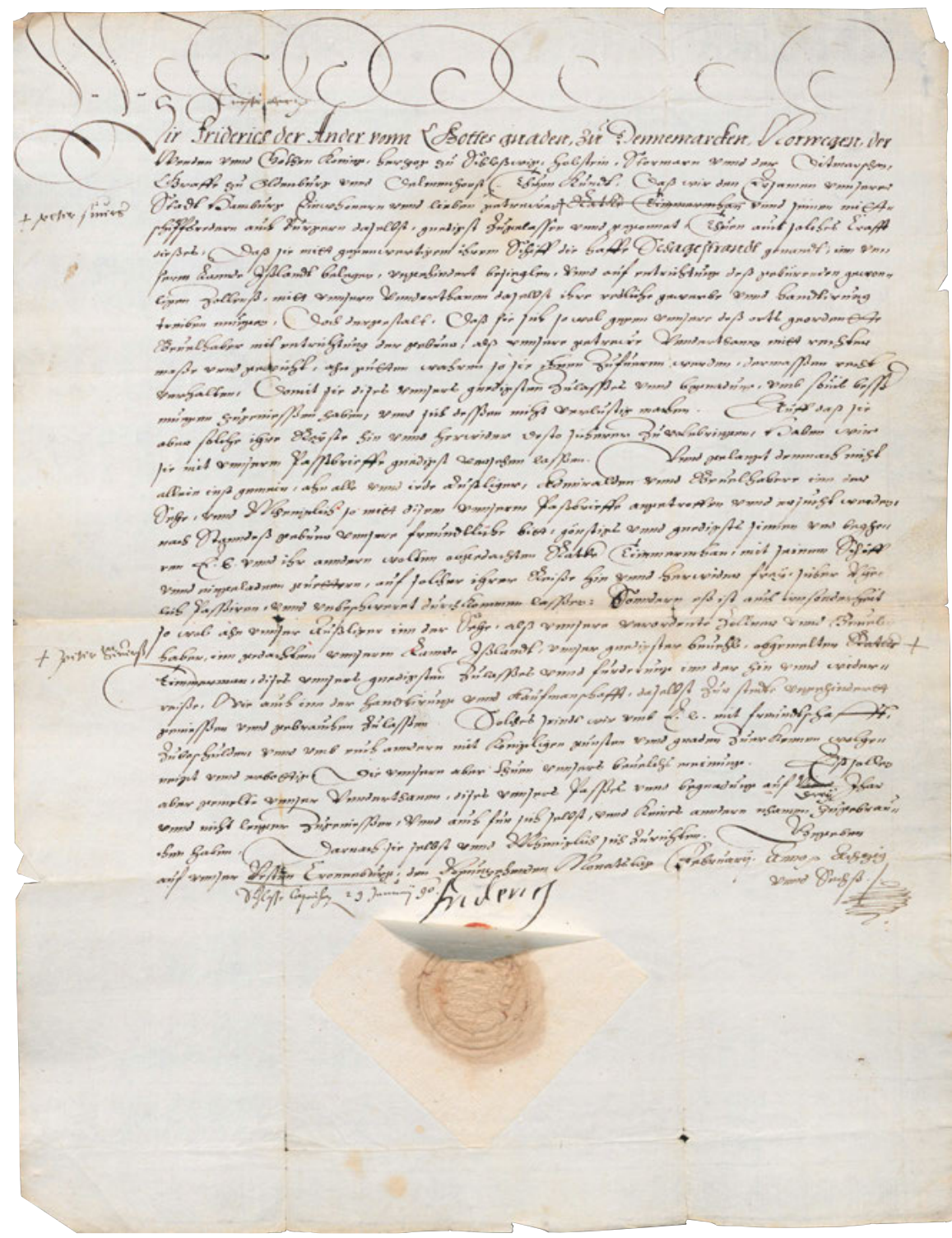

Figure 3.5: Licence from 19 February 1586 for the harbour Skagaströnd granted to Ratke Timmerman from Hamburg, which has been corrected to Peter Sivers. RAK D11, Pakke 28 (Suppl. II, 25). 
parties in $1562 .^{216}$ Frederick was resorting to a tactic applied by the Danish kings against the English traders in the fifteenth century, which allowed them to profit from economic activity they could not prohibit. In the 1560s, Frederick was in dire need of money, as the Northern Seven Years' War (1563-1570) with Sweden put a heavy strain upon the royal treasury. The war was a fruitless but incredibly costly exercise on both sides, with one effect being that Denmark had to reform its system of taxation in order to be able to continue funding it. ${ }^{217}$

However, the first licences for Icelandic harbours are only known from 1565, and the 1562 agreement did not benefit Hamburg at all. On 5 February 1563, Frederick wrote to the Hamburg authorities that the city's merchants must refrain from sailing to the harbours of Arnarstapi, Rif, and Grundarfjörour on the Snæfellsnes peninsula, as he had granted licences for those harbours to Danish merchants. ${ }^{218}$ Hamburg was quite displeased, and tried everything to retain its presence on Snæfellsnes, a region with rich fishing grounds and many fishing stations. The merchants asked the queen dowager Dorothea, Frederick II's mother, to mediate on their behalf, doubtlessly because under her husband's rule, Hamburg had had much more influence. ${ }^{219}$ However, Dorothea's appeals on behalf of the Hamburg merchants were unsuccessful, which was somewhat predictable given the poor relation with her son. ${ }^{220}$

In January 1565, Frederick II and the Danish Council of the Realm prohibited all Hamburg trade with Iceland, and captured Hamburg ships in order to force the city to loan them 100,000 daler. In return, Hamburg's merchants could use ten harbours in Iceland. ${ }^{221}$ The Hamburg merchants dealing with

216 "sieder anno 62 niemand zugelaßen ohne i. kon. may. besondere begnadung und erleubnus einige hafung in Ißland zu besuchen”. SAH 111-1 Islandica, vol. 3 (15851124KOB00). This refers to an agreement between Hamburg and Frederick II on 4 May 1562 in Copenhagen, according to which Hamburg had to pay 10,000 daler; see Baasch, Islandfahrt, 42. However, the text of this agreement only mentions the Icelandic trade when it prohibits the trade with sulphur: Commerzbibliothek, S/338 vol. 1.

217 Robert I. Frost, The Northern Wars: War, State and Society in Northeastern Europe, 1558-1721 (Edinburgh, 2000), 29-38; Wittendorff, På Guds og herskabs nåde, 310-311; Hauschild, "Frühe Neuzeit und Reformation," 429-33.

218 DI 14:49 (15630205FRE00).

219 RAK D11, Pakke 26 (Suppl. II, 16): Hamburg appeals for mediation to Dorothea and Dorothea's letter to Frederick II, 24 November / 5 December 1563 (15631100HAM01, 15631124HAM00, 15631205KOL00).

220 Wittendorff, På Guds og herskabs nåde, 218.

221 RAK D11, Pakke 26 (Suppl. II, 16) (15650000XXX00). These were Berufjörður, Básendar, Keflavík, Hafnarfjörður, Akranes, Patreksfjörður, Tálknafjörður and Bíldudalur, Dýrafjörður, Skutulsfjörður, and Álftafjörður (see Section 6 and Table 5.2). 
Iceland protested that they could not pay this sum, as the Icelandic trade did not yield enough profit. ${ }^{222}$ The delegation sent to Denmark to discuss the situation was only able to gain Frederick II's approval of Hamburg merchants sailing to Iceland that year to collect their debts, but they could not undertake new commercial activities. Moreover, they were not allowed to trade in Hofsós or in other harbours given to Danish merchants. ${ }^{223}$ It is unknown how the king reacted to renewed requests the next winter that Hamburg merchants be permitted to sail to Iceland again, ${ }^{224}$ but he must have softened his stance around 1566 or 1567, as the number of Hamburg ships sailing to Iceland reached normal levels again after a clear dip in 1565-6 (Figure 3.4). Actual licences for Hamburg merchants, however, had not yet been issued.

In fact, the first known licences seem to have been issued explicitly to counter Hamburg (and to a lesser extent, Bremen) dominance on the island, as they gave Danish merchants and their allies the opportunity to trade with Iceland as well. ${ }^{225}$ One such figure is Lübeck burgomaster Bartholomeus Tinappel, who sided with Denmark in the war with Sweden and was also a commander of the fleet during the war. He sought to profit from this service in August 1565 by acquiring a licence to trade with the harbours of Ísafjörður and Dýrafjörður in northwestern Iceland, which had been used by Hamburg merchants before. ${ }^{226}$

The case of Tinappel also immediately demonstrated the disadvantages of the licence system, as licences were now associated with a specific person instead of being based on the division of harbours governed by custom. Tinappel died the next year in a naval battle near Visby, whereupon a new licence was immediately issued to Christof Vogler, the scribe of Segeberg castle. ${ }^{227}$ Margaretha, Tinappel's widow, tried to continue her late husband's business there, and asserted her right to do so by emphasising his services in the war with Sweden in her appeals to the Danish court. Vogler for his part did not wish to yield his

222 Baasch, Islandfahrt, 43.

223 DI 14:242 (15650128FRE00); RAK D11, Pakke 26 (Suppl. II, 16): request and permission to sail to Iceland to reclaim debts, March / April 1565 (15650303HAM00, 15650405LUNO0); KB 1561-1565, p. 554.

224 RAK D11, Pakke 26 (Suppl. II, 16): requests from Hamburg, 12 December 1565 (15651212HAM00), 1566, 9 February (15660209HAM00), 12 February (15660212HAM00).

225 For a complete overview of licences, see Appendix A.

226 DI 14:289 (15650814KOB00); RAK D11, Pakke 26 (Suppl. II, 16): request of Tinappel (15650811KOB00).

227 DI 14:407 (5670129FRE00); Bei der Wieden, “Lübeckische Islandfahrt”, 20-21. 
position in the slightest, complaining when she sent a ship in 1567 to Iceland to reclaim the outstanding debts of her deceased husband. ${ }^{228}$

The licences provided Frederick with a legal means for breaking the dominance of Hamburg and Bremen merchants on the island, who had divided the harbours among themselves according to decades-old custom. For example, licences were also issued to Danish noble Birge Trolle for Búðir and Kumbaravogur, ${ }^{229}$ to Herman Oldenseel from Lübeck for Vopnafjörður in $1566,{ }^{230}$ and to Heinrich Mumme from Copenhagen for "Ostforde" (Berufjörour) around the same year. ${ }^{231}$ All these harbours had formerly been in use by Bremen, which was also accused of harbouring Swedish privateers in the River Weser. ${ }^{232}$ The city saw its presence in Iceland threatened as well, and sent ambassador Tyleman Zerneman to Copenhagen in 1567, who secured permission for Bremen merchants to remain active in these harbours. ${ }^{233}$ Licences were issued to Hamburg citizens as well in 1566, specifically Joachim Thim for Keflavík and Joachim Wichman for Hafnarfjörður. ${ }^{234}$ However, both were working in close cooperation with the Danish court: Wichman was Hamburg factor for the Loitz family, ${ }^{235}$ and both appear later as Danish factors in the trade with the Faroes. ${ }^{236}$

It is unclear how systematically the licences were issued and how much revenue they generated for the king. In the 1560s and 1570s, when the German presence in Iceland was often contested, licences seem to have been issued in specific circumstances to restrict or grant access to specific harbours. In 1576, Bremen merchant Bernd Losekanne stated, during a dispute with his former trading partner Christoffer Meyer in Berufjörður, that they "did not have to pay rent, like the others have to do, but only the tolls". ${ }^{237}$ Apparently, the king had

228 RAK D 11, Pakke 28 (Suppl. II, 22/23): Margaretha’s request, 4 April 1567 (15670404LUB00); reaction to Vogler's complaint, 21 February 1568 (15680221LUB00). Margaretha's appeals were not entirely in vain, as she was able to continue the business of her late husband for some years in another harbour; see Sections 6.4 and 7.4.3.

229 DI 14:327 (15660228KOB00). See Sections 6.3.1 and 6.3.5.

230 DI 14:328 (15660228KOB01). See Section 6.6.1.

231 DI 14:356 (15660617КОB00). See Section 6.6.3.

232 DI 14:346 (15660524BRE00).

233 DI 15:13 (15670926BRE00). See Sections 6.2.2, 6.3.1, 6.3.5, and 6.6.3.

234 DI 14:329 (15660303FRE00); DI 14:357 (15660625KOB0).

235 RAK D11, Pakke 26 (Suppl. II, 16): letter from skipper Franz Friese, 6 October 1566 (15661006HAM00).

236 See Sections 3.6 and 7.2.5.

237 "nur keine pacht, gelike andere doen möten, darvan gegevenn, sünder alleine mit entrichtinge des tollens, fry gewesenn". SAB 2-R.11.ff.: final plea of Christoffer Meyer against Bernd Losekanne, 13 February 1576 (15760213BRE00); See also Section 6.6.3. 
desired a payment for some of the licences, similarly to when he pressed Hamburg to pay for the ten harbours in 1565 but stopped trying to collect this fee once the war with Sweden ended. Prices for licences were therefore probably dependent on the situation. Only once, in 1577, is a price mentioned: Stade paid 300 Reichsthaler for the use of Ísafjörður and Álftafjörður for six years, on top of the tolls. ${ }^{238}$

The growing commercial power of Hamburg and its attempts to become the staple port for the lower Elbe region brought the city into more conflict with the Danish king. Frederick saw the Icelandic trade as a welcome means to put Hamburg under pressure. In 1574, the king wrote to the governor in Iceland that all Hamburg trade with the island was prohibited, the fish had to be exported to England only, and in the case that Hamburg ships appeared nevertheless, they should be captured. ${ }^{239}$ This was part of a larger campaign: over the next few years, all Hamburg trade in Danish territories was prohibited. ${ }^{240}$

However, Hamburg found means to circumvent the trading ban. In 1576 and 1577, merchants from Stade and Buxtehude acquired licences for the Icelandic trade. ${ }^{241}$ Merchants from these towns, located on the lower Elbe close to Hamburg, had never been active in the North Atlantic trade before. According to a letter of the Hamburg merchants trading with Iceland from 1577, many from their ranks had begun to operate from Copenhagen, Lübeck, Bremen, Lüneburg, Stade, Buxtehude, Kiel, and towns in Holstein. In Buxtehude, they had even bought a new ship for the purpose. ${ }^{242}$

However, the Stade and Buxtehude ships might not even have sailed to Iceland from those towns. As we can see from the number of ships returning from Iceland to Hamburg derived from the donation registers of the confraternity of St Anne in Hamburg (Figure 3.4), the number of ships trading with Iceland declined with over 50 percent between 1574 and 1578, but there were still about seven ships trading annually with Iceland in that period. This differs markedly from the outcome of the previous trading ban in 1564, when the number of ships dropped to almost zero, so we might conclude that many ships were simply sailing under false flag from Buxtehude and Stade, beyond the control of

238 RAK D11, Pakke 28 (ad Supplement II, 25): list of licences for harbours in Iceland, 1576-1585 (15860000XXX01).

239 NRR 2:112

240 Baasch, Islandfahrt, 46.

241 RAK D11, Pakke 28 (ad Supplement II, 25) (15860000XXX01); KB 1576-1579, p. 177; NRR 2:213.

242 SAH 111-1 Islandica, vol. 3: complaints from Hamburg merchants about the Danish trading ban, 3 June 1577 (15770603HAM00); Baasch, Islandfahrt, 46. 
Denmark, but were actually leaving from and returning to Hamburg. One entry in the Hamburg donation register from 1581 states this explicitly, as Jurgen Elers is recorded as having donated money from a Buxtehude ship. ${ }^{243}$

This state of affairs would not last long, as it was in the interest of both Hamburg and the Danish king to restore commercial relations. Upon a treaty being concluded in Flensburg on 5 July 1579 and confirmed in Wismar the situation was back to normal. From a resolution of the king from 1585, we learn that this treaty granted Hamburg 15 licences for harbours in Iceland, where they were free to trade except in sulphur, and that they had to acknowledge the rights of Bremen, Lübeck, and Stade to trade there as well, who were using eight other harbours in total. ${ }^{244}$

Until the introduction of the Danish trade monopoly in 1601, Hamburg merchants would enjoy two decades of relatively peaceful and free trade in Iceland, and the Hamburg North Atlantic trade experienced a considerable boom. This is suggested by the number of ships returning from the north (Figure 3.4), the continuing complaints from Bremen that they lost many of their harbours to Hamburg in the 1580s and 1590s, and the continuity of licences, most of which were reissued to the same group of merchants every few years.

Under the surface, however, the political situation had irrevocably changed. Hamburg saw the previous commercial situation restored, but the Danish king had strengthened his control over the island. One sign of this is the fact that the issued licences were issued for ever-shorter periods of time. Whereas the early licences were often issued for an unspecified time, from 1586 they were issued for a limited time, usually three or four years. The risk of losing a harbour to competitors was a real problem, made even more acute by the extensive extension of credit, which left merchants in danger of holding a great deal of debt on Iceland that they could not reclaim in case of loss of a licence. An extreme example is Bremen merchant Carsten Bake, who was granted licences for

243 "Jürgen Elers van dat Buxtehuder schip geven 1 daler". SAH 612-2/5, 2 vol. 1 (15330000HAM00), f. 271v; see also Kurt Piper, "Urkundliche Nachweise über die Buxtehuder Islandfahrt (1577-1581)”, Stader Jahrbuch NF, 57 (1967): 145-146.

244 SAH 111-1 Islandica, vol. 3 (15851124KOB00). Transcript in Baasch, Islandfahrt, 136-140. The harbours are not mentioned by name, but they can be determined from a list of Hamburg licences from 1586 (RAK Pakke 28 (ad Suppl. II, 25) - 15860213HAM00): Arnarstapi, Ríf, Barðaströnd, Ísafjörður, Hofsós, Vopnafjörður, Hornafjörður, Eyrarbakki and Porlákshöfn, Hafnarfjörður (with two ships), Keflavík, Básendar, Grindavík, and Skagaströnd. The eight other harbours must then be: Berufjörður, Kumbaravogur, Nesvogur, Búðir, Flatey, Grundarfjörður, Hólmur, and Straumur (see Section 6). The suggestion by Thomas, IJslandsvaarders, 14, that the island was divided in spheres of influence between Hamburg, Bremen, and Lübeck is not confirmed by the sources. 
different harbours every few years, and complained in 1593 that he still had many outstanding debts all over the island that he was not allowed to reclaim. ${ }^{245}$

The licence system thus created in effect a divide and rule policy, as merchants became more concerned with defending their individual interests in certain harbours than with common interests on the island. Although it can be assumed that before the introduction of licences there had been conflicts between merchants about the use of a certain harbour as well, such conflicts were likely resolved by the parties involved, and the use of a certain harbour was in large part dictated by tradition. The dispute mentioned above between Bernd Losekanne and Christoffer Meyer in 1576, who fought over the right to use the harbour Berufjörður, ${ }^{246}$ hints at this, when Meyer stated that "although [Losekanne claimed that] the lease of harbours has been abolished, each has his own usual harbour, which he has used and sailed to since 20,30 or more years, until the current day, without anybody's interference like before". ${ }^{247}$ The licences, however, now provided a legal means to prevent other merchants from using a harbour, as the same document recounts that "the skipper [from Bremen] expelled a skipper from Hamburg with our mentioned royal letter [i.e. the licence] from our harbour, who immediately, as soon as he had been shown the letter, left [the harbour] to us". ${ }^{248}$ Conflicts now often involved the Danish court, where both parties would vie for the king's favour in order to be granted the right to use a certain harbour.

From conflicts that arose later in the century, we learn that the licences were issued by the German Chancery of Denmark, a governmental department established in 1523 to handle external affairs and administer the Germanspeaking lands of Schleswig and Holstein. The chancery kept a register of the issued licences, as is indicated in a letter from Stade from 1578, in which royal treasurer Christoffer Valckendorf is said to have taken "a booklet from a separate

245 RAK D11, Pakke 25 (Suppl. II, 15): complaint of Carsten Bake, 28 February 1593 (15930228BRE01).

246 See Section 6.6.3.

247 "offt wol de pachte der havingen affgeschaffet, so hefft doch ein jede syne gewöntlike havinge, de he süßlange vor 20,30, unnd mehr jaren gehat unnd besegelt, noch beth up den hüdigenn dach, ane jemandes hinderinge, nah wo vor, tho gebrükenn”. SAB 2-R.11.ff.: final plea of Christoffer Meyer against Bernd Losekanne, 13 February 1576 (15760213BRE00).

248 "de schipper [...] einenn Hamborger schipper mit berordenn unsem hebbenden könninckliken breve, uth der sülvigen unser havinge gewiset, de sick ock thor stündt, alse öhme de breff getönet, dar uth gemaket, unnd uns wikenn mötenn”. SAB 2-R.11.ff.: final plea of Christoffer Meyer against Bernd Losekanne, 13 February 1576 (15760213BRE00). 
room, in which the fjords of Iceland were listed". ${ }^{249}$ However, their information about the geography and local circumstances in these fjords seems to have been limited. In 1584, the king complained that he was overloaded with requests for licences for harbours in Iceland, but could not get enough information from the chancery. ${ }^{250}$ It is likely that the German merchants, who sailed with many ships to Iceland each year, knew the country better than the chancery, which had to rely on Danish officials on Iceland for information, information that was not always accurate.

This situation led to a number of conflicts, as merchants (deliberately) acquired licences for harbours that were already being used by others. The most serious dispute involved the fjord Berufjörður in eastern Iceland in 1590-1591. Bremen merchants had held a licence for the fjord under the name "Ostforde" for decades; in 1590, the chancery allegedly made a mistake when it renewed this licence, issuing a new one for "Wapenforde", which was a different fjord (Vopnafjörður) already in use by the merchant Paul Lindeman from Hamburg. The Hamburg city council noted on the occasion that it was "not uncommon, that one harbour is confused with another". ${ }^{251}$ Although the mistake was quickly discovered, and the Bremen merchants requested the licence to be changed, Hamburg took advantage of the resulting confusion to request a licence for the same fjord as well under the local name "Bernforde" (Berufjörour). The chancery, which obviously had no idea this was essentially the same harbour, granted the request, resulting in a dispute between Bremen and Hamburg merchants about who had the right to use the harbour. Both parties provided testimonies from locals supporting their claims, Bremen stating that "Ostforde" and "Bernforde" were essentially the same harbour, and Hamburg stating that there was no place called "Ostforde". In the end it was decided that it was impossible to prove who was right, and both licences were deemed valid. ${ }^{252}$ Bremen merchants successfully played the same trick in 1597, when they acquired a licence for the harbour "Stickingsholm" (Stykkishólmur); Oldenburg merchants

249 "aus einem sonderlichen gemach ein buchleinn, in welchem die vorde des Ißlandes verzaichnet gewesen”. RAK D11, Pakke 25 (Suppl. II, 15): complaint of Stade merchants about confusion of licences, 20 January 1578 (15780120STA00).

250 KB 1584-1588, p. 30.

251 "unnd nicht ungewönlich sein muge, daß eine have vör die andere benennet werde”. RAK D11, Pakke 26 (Suppl. II, 18a): request for renewal of Paul Lindeman's licence for Vopnafjörður, 2 January 1590 (15900102HAM00).

252 See Section 6.6.3. 
contended this was a part of the harbour Nesvogur, where they had been trading. Bremen had lost Nesvogur to Oldenburg before. ${ }^{253}$

\subsubsection{Influence of the nobility}

A second sign of the growing dominance of the Danish crown in Iceland is the influential role that the Danish nobility, German princes (especially members of the House of Oldenburg, to which the Danish king belonged) and merchants from the Danish-held territories of Schleswig and Holstein came to play in the last decades of the sixteenth century. We have already seen how Hamburg merchants appealed to the queen dowager Dorothea when they saw their interests in Iceland threatened by her son Frederick II. This proved to be a preview of a practice that would become more or less standard in the decades that followed. Requests for licences were often accompanied by letters of mediation by leading Danish nobles or members of the House of Oldenburg.

The importance of the former becomes apparent around the ascent of Christian IV to the Danish throne (1588). As Christian was only eleven years old when he succeeded to the throne, a regency council was set up that consisted of four members of the Danish Council of the Realm. Until 1596, when Christian was deemed old enough to take on royal responsibilities, the councillors' names and signatures appeared on the issued licences. In that same period, many requests for licences from German merchants were directed towards the council or they were asked for mediation. ${ }^{254}$

The importance of the second group, German princes, reflected the changing power relations between the German towns and the Danish king. Hoping to influence royal policy, the towns would turn to their formal overlords, with whom they often had a troubled relation. Especially significant is the role of members of the House of Oldenburg, who were related to the Danish royal family and held high-ranking positions in various German princedoms. For example, Bremen merchants and the city council solicited Duke John Adolf of HolsteinGottorp, who became prince-archbishop of Bremen in 1585, to assist with the acquisition of licences in Iceland. As early as 1566 appeals were made to Joachim Hinck, dean of the Bremen cathedral chapter and as such representative of

253 See Section 6.3.6.

254 Wittendorff, På Guds og herskabs nåde, 321-328. 
the archbishop, for help with regard to licences for the harbours Keflavík and Grindavík. ${ }^{255}$

A similar role was played by the Count of Oldenburg, who had personal connections with the Danish king. In 1579, Joachim Kolling from Hooksiel in the land of Jever, which belonged to Oldenburg, sought to acquire a licence for the harbour Kumbaravogur. Kolling had sailed in the service of Bremen merchants to Iceland before, so he was familiar with the situation there, and when licence holder Johan Munsterman, a Bremen skipper, died in a shipwreck in 1578, Kolling saw an opportunity to sail there for himself and acquired a licence through the mediation of Count John VII. ${ }^{256}$

At the same time, the growing influence of these nobles in the issuing of Icelandic licences came to pose a threat to the interests of German cities in Iceland, as the nobles might decide to acquire licences for themselves. The counts of Oldenburg in particular are known to have had strong interests in the North Atlantic trade: Count Anthony received permission in 1557 to sail for one year to Iceland without having to pay tolls, ${ }^{257}$ and might have sent ships there in a couple of years. In 1563, he tried in vain to acquire a licence for the Faroes, claiming that he needed fish for the provision of his castles and fortifications. ${ }^{258}$ Normally, the count would get this fish from Bremen, as is attested by the sale of Icelandic stockfish to him by Bremen councillor and merchant Hinrick Salomon in $1570 .^{259}$ It is therefore no surprise that when Joachim Kolling's enterprise was no success, probably because of financial difficulties, Count John VII requested a new licence for Kumbaravogur in his own name. ${ }^{260}$

Other princes pursued similar interests. When Bremen merchants asked Prince-Archbishop Henry III to mediate for them concerning a licence for the

255 RAK D11, Pakke 25 (Suppl. II, 15); SAB 2-R.11.ff. (15660329BRE00); H. Hertzberg, "Das Tagebuch des bremischen Ratsherrn Salomon 1568-1594”, Bremisches Jahrbuch 29 (1924): 37; on Joachim Hinck, see Krause, "Hyncke, Joachim”, Allgemeine Deutsche Biographie, 1883, accessed 17 July 2018, https://www.deutsche-biographie.de/pnd140745114.html.

256 NLO, Best. 20, -25, no. 6 (15791211SKA00); Kohl, “Oldenburgisch-isländische Handel”, 37. See Sections 6.3.5 and 7.2.1.

257 KB 1555-1560, p. 93; DI 13:376.

258 Dietrich Kohl, "Überseeische Handelsunternehmungen oldenburgischer Grafen im 16. Jahrhundert”, Hansische Geschichtsblätter 16 (1910): 425-427; Ásgeirsson and Ásgeirsson, Saga Stykkishólms, 70-71.

259 Hertzberg, “Tagebuch”, 37.

260 NLO, Best. 20, -25, no. 6: request of the Count, 13 February 1585 (158502130LD00). See also Sections 6.3.5 and 7.2.1. 
harbours Nesvogur and Grundarfjörður in 1583, they received the answer that the archbishop had not received an answer from the king yet, and advised them to wait patiently. Little did they know that Henry in the meantime was busy trying to acquire a licence for himself, and were unpleasantly surprised when Frederick II issued a licence to Henry for Nesvogur and Grundarfjörður on 3 May $1584 .{ }^{261}$ Henry hired a skipper from Bremen, Bruning Nagel, to sail for him, who of course incurred the wrath of his fellow citizens who had been sailing to those harbours previously. The Bremen council tried to find a middle way by demanding that Nagel and the others form a trading company together. ${ }^{262}$ The situation seemed to turn to the advantage of the city when Henry died in April 1585, and Bremen merchants requested a new licence for both harbours. However, Frederick II answered that the licence for Nesvogur and Grundarfjörður had already been issued to the Count of Oldenburg. ${ }^{263}$

In the previous decade, the Duke of Holstein-Gottorp, Adolf, a half-brother of King Christian III, had used the prohibition against Hamburg merchants sailing to Iceland in 1573 to his advantage, fitting out a ship in Kiel to sail to Iceland for him, and asking for and receiving an exemption from the Sound Toll from the king. ${ }^{264}$ Hamburg merchants complained jealously when he subsequently ordered a skipper from Hamburg to sail the ship for him, although they were not allowed to sail there themselves. ${ }^{265}$ Adolf's activity in the north did not stop when Hamburg reconciled with the king, apparently continuing until his death in 1586; at least in 1585, there is still mention of his ship having visited the harbour Straumur near Hafnarfjörður. ${ }^{266}$

Finally, the last decades of the sixteenth century were characterised by the growing importance of merchants from towns in Holstein in the Icelandic trade. As these regions were subjects of the Danish king or his relatives, the emergence of these persons in the North Atlantic trade further testifies to the changed relations. From the 1560s onwards we encounter merchants from towns in the Danish part of northern Germany like Wilster, Rendsburg, Kiel, and Segeberg.

261 SAB 2-R.11.ff.: correspondence between Bremen, the archbishop, and King Frederick II, June 1583-April 1584 (15830612BRV00; 15830927BRE00; 15831024DRI00; 15840422BRV00; 15840503SKA00, 15840503SKA01).

262 SAB 2-R.11.ff.: declaration of Henry III, 10 August 1584 (15840810BRV00); decision of the city council, 3 February 1585 (15850203BRE00). See also Section 7.2.1.

263 SAB 2-R.11.ff. (15851120BRE00; 15851217KRO00).

264 RAK D11, Pakke 24 (Suppl. II, 10) (15730625GOT00).

265 RAK D11, Pakke 26 (Suppl. II, 16): complaints of April 1573 (15730419HAM00, 15730420HAM00).

266 RAK D11, Pakke 24 (Suppl. II, 7): list of Icelandic harbours, 1584-1592 (15840000KOB00). See Section 6.2.5. 
For example, three citizens from the town of Wilster in the Elbe marshes downstream of Hamburg received a licence for Básendar and Pórshöfn in 1584, although it is unclear if they used it. ${ }^{267}$ By favouring his citizens in this area (which belonged to the royal part of Holstein), Frederick II might have been pursuing a strategy that would be taken up by his successor Christian IV in founding the city of Glückstadt a few decades later (see next section).

Furthermore, the king apparently rewarded persons in his service with a licence for a harbour in Iceland. An early example is the enfeoffment of Thomas Koppen, former secretary of Frederick I, with the Faroes in $1529 .^{268}$ We have already noted that Bartholomeus Tinappel, admiral in the Danish navy, and Christof Vogler, scribe of Segeberg castle, received licences for Ísafjörður in 1565 and 1567, respectively. Around 1596, Rotman Pöner received a licence for the harbours Straumur and Vatnsleysa through the connections of his father, who was the royal toll collector in Rendsburg. Although Rotman himself may have been a merchant in Hamburg, and certainly worked with other merchants in the city who were trading with Iceland, it was his father's position in Rendsburg that was instrumental in his acquisition of the licence. ${ }^{269}$

Other merchants from Schleswig and Holstein met with less success: Flensburg merchant Claus Jacobsen requested various licences around 1590, but no actual licence in his name exists and there is no evidence of him having actually been to Iceland. Also, the town of Oldesloe tried, unsuccessfully, to acquire a licence for Michael Barchstede. ${ }^{270}$

The importance of cooperating with merchants who had connections to the Danish court was expressed explicitly by Bremen merchants in 1580. In a complaint about the loss of the licence for Kumbaravogur to Oldenburg merchant Joachim Kolling, the widow of Johan Munsterman, who had held the previous licence before his death, stated that "to further the matter, [we] have included one of our [fellow] citizens, with the name Heinrich Rulves, the son of Rulf von Deventer, the master of artillery of the royal majesty of Denmark, in our company, and therefore [we] hope to heighten our chances at the royal majesty's court, as he is tempted to privilege his own subjects before foreigners". ${ }^{271}$

267 RAK D11, Pakke 28 (ad Suppl. II, 25): list of licensed harbours, 1576-1585 (15860000XXX01). 268 See Section 3.6.

269 RAK D11, Pakke 24 (Suppl. II, 9): letter of Niels Busk to Fritz Pöner, 14 January 1596 (15960114AAR00).

270 RAK D11, Pakke 24 (Suppl. II, 11): letters from Oldesloe, 1600 (16000102OLD00; 16000103OLD00)

271 "zu mehrer befurderung der sachenn einenn unser burger mit nahmen Heinrich Rulves, der kon. matt. zu Dennemarckenn zeuchmeisters, Rullf von Deventers sohn, mitt, unnd neben 


\subsubsection{The Danish trade monopoly in $\mathbf{1 6 0 2}$}

Christian IV, who had inherited the Danish throne in 1588, became known for his implementation of a successful mercantilist economic policy during his long reign, which made Denmark an important player in Europe. With regards to the North Atlantic trade, he intensified the effort, initiated by his predecessors, to exercise control over that trade. On 24 July 1601 he sent a decree to the cities involved in the Icelandic trade, which informed them that he had given the right to trade with Iceland to his citizens in Copenhagen, Helsingør, and Malmö, and all foreigners were prohibited from trading there from now on. ${ }^{272}$ This introduction of the Danish trade monopoly in Iceland was part of a larger campaign to reduce Hanseatic influence in the Danish realm. For example, in Scania German elements had been removed from the churches in 1600, such as windows, pews, and German tombstones. ${ }^{273}$

The German merchants, therefore, must have seen the ban coming, but were hoping that it would be a temporary measure like earlier trading bans. Hamburg merchants complained bitterly about the king's decision, particularly on the grounds that they were not able to reclaim their outstanding debts. ${ }^{274}$ Multiple times during the seventeenth century they requested permission to sail to Iceland again, but their requests were always denied. Moreover, having a relationship with the king no longer guaranteed a licence. The Count of Oldenburg's requests for renewal of the Icelandic trade, which coincided with those of Hamburg, were similarly denied in 1603 (when the last licences ended), 1611 (when rumours had apparently spread that the king was about to open Iceland to foreigners again), and 1645 (after Christian IV had granted him exemptions to tolls in the Sound and Norway). ${ }^{275}$ In Bremen, we know only about objections directly after the prohibition was declared: probably they chose to focus on Shetland, where they had built up a strong position in the course of the sixteenth century.

uns in unsere geselschafft verstattet, und dahero desto mehr befurderungh an der kon. matt. hoff, alß die derselben underthanenn vor frombden zu befurderen geneigtt, unns undterthenigst vertrostenn”. RAK D11, Pakke 25 (Suppl. II, 15): 1 December 1580 (15801201BRE00).

272 Only the letters sent to Oldenburg (NLO, Best. 20, -25, no. 6 - 16010724KOBO0) and Bremen (SAB 2-R.11.ff. - 16010724KOB01) have survived.

273 AHL Schonenfahrer, nos. 1160, 1166.

274 RAK D11, Pakke 27 (Suppl. II, 19); SAH 111-1 Islandica, vol. 4: Hamburg complaints, 29 October 1601 (16011029HAM00).

275 Baasch, Islandfahrt, 51-54. NLO Best. 20, -25, no. 6: 1603 requests for a licence for Ólafsvík (16030200OLD00, 16030200OLD01, 16030310FAL00); 1611 requests (16110207OLD00, 16110307KOB00); 1645 request (16450000OLD00). 
In 1601, a large number (thirteen) of issued Icelandic licences expired, making it easier to get rid of the Germans there as quickly as possible. ${ }^{276}$ Another eleven licences were still valid for one or two years, ${ }^{277}$ and although Christian IV theoretically guaranteed the validity of these licences, and spurred the Germans to reclaim their outstanding debts, there are numerous signs that he was reluctant to honour these commitments. For example, merchants in the harbour Hvalfjörður, who lost their licence during a shipwreck in 1601, were not given a copy of their (still-valid) licence, but only a letter in which the king stated that they were permitted to transport their goods on the ship of the merchants in Hafnarfjörður. Though the latter refused to do so, on the grounds that they did not even have enough space on board for their own goods, the king did not grant the former Hvalfjörður merchants a year's extension. ${ }^{278}$ Also, it seems that the locals were instructed to avoid trading with the Germans. Hamburg merchants in Iceland wrote in 1602 that they had heard from governor Ewalt Kruse that "he had a letter from the king in his possession, in which all Icelanders were forbidden to pay their debts to the Germans, and not to sell them anything, but only to the Danes, until they had enough, and that this order was announced to the people by the preachers in each parish". ${ }^{279}$ In the meantime, Danish merchants were complaining about the interference of German merchants in certain harbours, even though they still had valid licences. $^{280}$

The German merchants in Iceland therefore had a hard time getting their debts repaid and transporting all of their stockfish and other commodities back home, as the many disputes between merchants with Iceland from Hamburg bear out. Typically, merchants tried to pay for space on the ships of fellow merchants who still had valid licenses for harbours (predominantly Hafnarfjörður) in order to bring their goods back to Hamburg. ${ }^{281}$ To make matters worse, 1602

\section{Baasch, Islandfahrt, 50.}

277 RAK D11, Pakke 24 (Suppl. II, 8): 1601 list of licensed harbours (16010000XXX00).

278 RAK D11, Pakke 27 (Suppl. II, 19) (16030305HAM00).

279 "ehr von kon. maytt. unserm gnedigsten hern ein schreiben in henden hette, darinne allen Ißlandern wurde verbotten, das sie keinen Teutschen ihre schulde bezahlen, auch denselben nicht vorkauffen, besondern alleine mit den Dennemarckern handlen solten, biß dieselben berivet weren, inmassen dan sothan koniglich befelh durch die prediger daselbsten den cirspiel leuten were angekundiget worden”. RAK D11, Pakke 27 (Suppl. II, 19) (16020913HAM00).

280 RAK D11, Pakke 27 (Suppl. II, 19): complaints of Copenhagen merchants about interference in Básendar, August 1602 (16020800KOB00).

281 SAH 111-1 Islandica, vol. 4: controversy about the hire of shipping space between Keflavík and Hafnarfjörður merchants from Hamburg, 1602-1604 (16021126HAM00; 16030400HAM00; 16030505HAM00; 16040111HAM00; 16040123HAM00). 
was a particularly bad year in terms of weather: the winter was particularly cold, causing many animals to die and as a consequence the Icelanders were suffering from famine. Fish catches had been bad, and in the summer there was still so much sea ice that harbours in the North could not be reached. ${ }^{282}$ As a result it must have been impossible for German merchants to reclaim many of their stilloutstanding debts on the island, and they must have suffered great losses.

Contrary to the hopes of merchants from the German cities, Christian's decision was definitive, and the resulting Danish trade monopoly in Iceland was to last well into the nineteenth century. In 1614, he renewed the monopoly for the Danish cities, and in 1619 the Copenhagen Icelandic company was founded, which was to be the only company to trade with Iceland, thereby cutting Helsingør and Malmö out of this trade altogether. ${ }^{283}$ One of the reasons behind this was that the initial Danish trade monopoly had left too many back doors open for German merchants to remain in the Icelandic trade. In 1602, for example, we hear about a ship from Helsingør that was led by a merchant and a helmsman from Hamburg. ${ }^{284}$ Though the king had stated in 1602 that he wanted to give his own subjects the chance to trade in Iceland as well, the reality was that the Danish merchants were still dependent on their German peers, because the latter possessed often lifelong experience of the sailing routes and conditions on the island. ${ }^{285}$ Indeed, the data from the donation register of the Hamburg confraternity shows donations from up to seven ships annually until 1627 (Figure 3.4), many of which are indicated to have sailed for Danish merchants.

Moreover, Hamburg's city council, well aware of its citizens' experience in the North Atlantic trade, tried to retain the position of the city as staple port for Icelandic produce. Article 29 of the town law of Hamburg from 1603 explicitly prohibited citizens who traded with Iceland to sail from other cities under penalty of expulsion. ${ }^{286}$ The strong Hamburg market for Icelandic commodities also attracted Danish ships to the city: the Hamburg Schifferbücher frequently record the arrival of 10 to 20 ships from Iceland annually until c. 1620, which does not square with the data from the account book of the Hamburg confraternity, so these must largely have been Danish ships. ${ }^{287}$ In 1619, the king inserted a clause into the monopoly charter for the Copenhagen Icelandic company stating that

282 See Section 4.1.2.

283 Baasch, Islandfahrt, 51; Thomas, IJslandsvaarders, 51; Aðils, Monopolhandel, 98-103; Gunnarsson, Monopoly Trade, 54-55.

284 RAK D11, Pakke 27 (Suppl. II, 19): witness accounts, 30 August 1602 (16020830HAM00).

285 See Sections 4.1.2 and 6.2.3.

286 Baasch, Islandfahrt, 52; Bartels, Grundgesetze, 228.

287 Baasch, Islandfahrt, 48. 
Danish merchants must bring at least half of the Icelandic commodities to Copenhagen. ${ }^{288}$ The numbers of ships in the Hamburg donation register do indeed decline after this time, although Lübeck merchants might have taken over for a while: between 1619 and 1637, the Sound Toll registers recorded one or two ships yearly from Iceland to Lübeck. ${ }^{289}$

Among other consequences, the introduction of the Danish trade monopoly spurred illegal activity in the North Atlantic. The Germans, along with the English (who had retained their commercial presence in Iceland during the sixteenth century, mainly fishing, but also sometimes trading) and the Dutch took part in this. In 1616, Christian prohibited smuggling of commodities from Iceland by all foreigners, and later sent warships to patrol the waters around the islands. ${ }^{290}$

Now the Germans had been largely removed from the North Atlantic trade, the king faced another problem: the Copenhagen merchants returning from the North Atlantic often made for Hamburg instead of Copenhagen, because of the large and well-established market there with strong connections to central and southern Europe. In order to undercut the dominant economic position of Hamburg in northern Germany, the king founded Glückstadt, on the Elbe downstream of Hamburg, to compete with the latter. The town was made staple port for Icelandic produce, and the Copenhagen Icelandic Company was allowed to set up scales for Icelandic commodities in the town in 1623. However, it proved to be impossible to circumvent Hamburg altogether: the continuing attractiveness of the established market nearby spurred the king to take additional steps to guarantee the position of Glückstadt as the Icelandic staple market. Icelandic commodities had to be offered for sale in Glückstadt, but as many of them were sold in Hamburg in the long run, Christian ordered in 1645 that all commodities had to be stored in Glückstadt first and sold there as well. In response, commodities were sold directly on to Hamburg merchants and ended up on the Hamburg market again. Thereupon it was ordained in 1662 that commodities could only be transported further on Glückstadt ships, and in 1708 it was proclaimed that they must be stored in Glückstadt for at least eight days. ${ }^{291}$

288 Thomas, IJslandsvaarders, 18.

289 Bei der Wieden, “Lübeckische Islandfahrt”, 25; Nina Ellinger Bang, ed., Tabeller over Skibsfart og Varetransport gennem Øresund 1497-1660. udarbejdede efter de bevarede Regnskaber over Øresundstolden 11 (Copenhagen, 1906).

290 Ketilsson, Kongelige Forordninger, 1776, 2:362-364.

291 Baasch, Islandfahrt, 55-56. RAK D11, Pakke 27 (Suppl. II, 19): letters of Danish kings to the governors of Glückstadt, seventeenth century. 


\subsection{Hamburg and the Faroe Islands}

Thanks to an ample number of sources, much is known about the history of German trade in Iceland. For the Faroe Islands, on the other hand, there is a source deficit. Moreover, many statements have been made in the past with regard to the influence of the Germans in the Faroes in the fourteenth and fifteenth centuries, that often seem to be based more on wishful thinking than a critical assessment of the few primary sources that we do have. As we have seen, there is some evidence of activity of Danzig merchants in the Faroes in 1486, but other than that, the Faroes are only ever mentioned in combination with other skattlands, so it is difficult to assess whether this means merchants actually sailed there. There is a clear increase of German commercial influence from the late fourteenth century onwards, with the appointment of German bishops in the Faroes, the construction of a church of St Brendan in the 1420s (a cult that presumably spread to Scandinavia from the North Sea area), and the adoption of the Hamburg ell and the gylden in the system of measurements in the fifteenth century. ${ }^{292}$ However, this points more at a growing German influence in Bergen than at direct trade with Germany. ${ }^{293}$ A permission for Hanseatic merchants to trade with the Faroes in 1361, which some scholars mention, ${ }^{294}$ is probably a faulty interpretation of a charter from 18 June that year, in which Bergen merchants receive permission to trade with the skattlands. However, the charter explicitly speaks of domestic (i.e. Norwegian) merchants in Bergen. ${ }^{295}$

The Faroes therefore seem to have remained much more closely linked to Bergen than Iceland and Shetland. ${ }^{296}$ It is possible that the lesser commercial importance of the Faroes in comparison with the other North Atlantic islands, combined with the tolerant attitude of the Danish kings towards trade with Iceland and the transfer of Shetland to Scotland after 1469, made violating the Bergen privileges to trade with the Faroes unappealing to Hanseatic merchants.

292 Mortensen, “Økonomisk udvikling”, 98-106; Símun V. Arge and Natascha Mehler, "Adventures Far from Home. Hanseatic Trade with the Faroe Islands", in Across the North Sea. Later Historical Archaeology in Britain and Denmark, c. 1500-2000 AD, ed. Henrik Harnow et al. (Odense, 2012), 175-78.

293 Cf. Mortensen, “Økonomisk udvikling”, 106.

294 Joensen, "Fishing”, 312; Joensen, Mortensen, and Petersen, Føroyar, 8; G. V. C. Young, From the Vikings to the Reformation. A Chronicle of the Faroe Islands up to 1538 (Douglas, 1979), 95.

295 "inlenskir kaupmen j Biorghvin”. R. Keyser et al., eds., Norges gamle love indtil 1387., vol. 3 (Christiania, 1846), 181-182.

296 Andras Mortensen et al., "Opdagelse af landene i Vestnorden”, in Naboer i Nordatlanten. Færøerne, Island og Grønland. Hovedlinger $i$ Vestnordens historie gennem 1000 år, ed. Jón Th. Thor et al. (Tórshavn, 2012), 101. 
This also meant that the Faroes remained under tighter Danish-Norwegian control, and can be considered a kind of experimental region for mercantilist measures that were introduced to the Faroes decades before they appear in Iceland, such as licences and the importance of Danish factors in the trade.

The first references to such measures date from the 1520s, a chaotic time for the Faroes that reflected the political situation in Denmark. A document from 1524 or 1525 from Cornelius Double, secretary of the exiled King Christian II, describes the attempts to arrest the Hamburg merchant Joachim Wullenwever in the Dutch harbour of Veere. ${ }^{297}$ According to this document, Wullenwever was given the Faroes as a fief in or before 1520, which gave him the sole right to trade there and to collect taxes for the king. Wullenwever is in fact the first person known to have received this position. This started a tradition of monopolies for the islands, which continued until $1709 ;^{298}$ the monopoly was given to one or several persons at a time in return for tax collection. It is unsure how and why Wullenwever was given this monopoly, but it is possible that he had been active in the north, e.g. in the Bergen trade, and was being rewarded for his (financial) support of the king, who was involved in an unsuccessful war with Sweden in an attempt to keep the country in the Kalmar Union. ${ }^{299}$

After Wullenwever's fief expired, he was given the right to trade there for one more year (1521) to attend to unfinished business and reclaim his outstanding debts, but he misused this permission. He was accused of having appropriated goods from the new governor Niclas Priester, goods that had previously been confiscated from a woman who was accused of having murdered her child, and who had had an affair with Wullenwever. As it happened, Wullenwever surprised Niclas in his own house, severely injured him and drove him out of the country. Moreover, he was accused of having illegally sold his wrecked ship to the bishop, although according to a 1521 law it should belong to the king. ${ }^{300}$

The letter of Double continues that in 1524, Christian II appointed Frederyck de Vriese as new governor of the Faroes, ${ }^{301}$ the inhabitants of which had not yet

297 Evensen, Savn til Føroyinga sögu, no. 15; Samlinger, 365-375.

298 Debes, Føroya søga, 2:163; Arge and Mehler, “Adventures Far from Home”, 178; Joensen, Mortensen, and Petersen, Føroyar undir fríum handli, 192. See Appendix B.

299 Johann Martin Lappenberg, "Joachim Wullenwever, Hamburgischer Oberalte und Rathsherr”, Zeitschrift des Vereins für Hamburgische Geschichte 3 (1851): 112.

300 Lappenberg, 113; Zachariasen, Føroyar, 162-163.

301 It is unclear what happened in the years in between. In a letter of 22 April 1524, Jørgen Hanssøn, who had been governor of Bergen under Christian II and also moved to the Netherlands following Christian's downfall, complained to the former king that under the current conditions, it was impossible to make use of his enfeoffment with the Faroes: "jeg tacker ether nåde ydmygelighen fore Feriø som ether nade meg wnt oc forlent haffuer end dog ieg nw 
sworn allegiance to the new king. As the king was already exiled in Holland by this time, this Frederyck was probably a Dutchman or Frisian, which is also suggested by his name. ${ }^{302}$ Frederyck tried to confiscate Wullenwever's wrecked ship in the king's name, but Wullenwever made use of the chaotic situation to prevent this. He sailed illegally to the Faroes, kidnapped de Vriese, and appropriated the taxes due the king. It is, however, unclear what his real motives were, as we only know one side of the story: he might have had a rightful claim to some of the tax revenue. $^{303}$

The new king Frederick I granted the monopoly for the Faroes in November 1524 or 1525 to Peder Fresenberg. ${ }^{304}$ Zachariasen assumes that Fresenberg was from Hamburg as well, which was met with much antipathy from Bergen: governor Vincent Lunge responded by trying to bring the Faroes back under Bergen control. In 1526, he sent a ship and soldiers to the Faroes "to free the land again [from Hamburg] for the Norwegian crown". ${ }^{305}$ It is not known what the result of this undertaking was, but attempts to bring the Faroes back under Bergen control were unsuccessful in the long run. In February 1529, the new Bergen governor Eski Bilde received the Faroes as a fief, but in November the same year, another Hamburg merchant, Thomas Koppen, was granted the monopoly for the sum of 100 Lübeck mark annually. ${ }^{306}$ Koppen had been King Frederick's secretary when he was still only Count of Holstein and had served him during negotiations with Christian II in 1522; he exploited his good standing with the king to become monopolist in the Faroes. ${ }^{307}$

Not much later, we hear about Joachim Wullenwever in the Faroes again. Koppen and Wullenwever were leading figures in Hamburg at that time: both are known to have been Oberalte (members of the governing councils of the parish churches) in the city. Wullenwever played an active role in the introduction of the Reformation in Hamburg around 1529 and became a member of the

effter thenne leligheidt ingen profiit kand haffue ther aff meg hobes dogh met gudz hielp thet skall icke lenge ware” (Evensen, Savn til Føroyinga sögu, no. 12.; DN 6:691). See Joensen, Mortensen, and Petersen, Føroyar undir fríum handli, 9, 190; Zachariasen, Føroyar, 164; for Hanssøn, see Halvard Bjørkvik, “Jørgen Hanssøn”, Norsk biografisk leksikon, 2005 1999, accessed 21 June 2018, https://nbl.snl.no/Jørgen_Hanssøn.

302 Zachariasen, Føroyar, 163.

303 Lappenberg, “Joachim Wullenwever”, 113-115.

304 Evensen, Savn til Føroyinga sögu, no. 16.

305 Debes, Føroya søga, 2:16; Zachariasen, Føroyar, 164.

306 Zachariasen, Føroyar, 165, 183. The sum of 100 Lübeck mark is first mentioned in 1532: Evensen, Savn til Føroyinga sögu, no. 35.

307 Anton Degn, Nøkur gomul, áður óprentað brøv o. a. Føroyum viðvíkjandi (Tórshavn, 1939), 13-14. 
city council in the 1530s; and Koppen started a foundation for retired priests and their widows through his will in 1547. They must have known each other well. In December 1531 the Danish king testified that Koppen and Wullenwever had appeared before him two years earlier (i.e. from the beginning of Koppen's monopoly) and shared the monopoly, with Wullenwever apparently managing the practical side of business. ${ }^{308}$ This led to protests by the archbishop of Trondheim, in response to which the burgomaster of Hamburg defended the position of his fellow citizens before the Hanseatic Diet in $1533 .^{309}$ The involvement of Koppen and Wullenwever in the Reformation in Hamburg and the resistance of the Norwegian church against their presence in the Faroes leads Zachariasen to believe that they were the driving force behind the introduction of the Reformation in the Faroes. ${ }^{310}$ This is not impossible, but hard to prove due to the absence of sources.

The Count's Feud in 1533-1534 posed challenges to Wullenwever and Koppen's position in the Faroes. The Norwegian nobility saw the death of King Frederick I and the resulting absence of a king as an opening for bringing the Faroes back under Bergen control. Claiming that with the death of the king the monopoly of Koppen and Wullenwever had lost its validity, Bishop Amund of the Faroes complained about the presence of the Hamburg merchants and sent a ship to Bergen himself with wadmal, feathers, and other commodities on board, with the support of Bergen governor Eski Bilde. Koppen responded by soliciting written support from members of the Danish Council of the Realm and kept his monopoly. ${ }^{311}$ Moreover, the Norwegian Council of the Realm was abolished in 1536, which removed the main opponents of the position of the Hamburg citizens in the Faroes.

For Wullenwever, however, things changed for the worse. The Hamburg city council supported Lübeck's involvement in the Danish civil war, albeit reluctantly. Joachim Wullenwever had a large hand in this, as his brother Jurgen, burgomaster of Lübeck, had been the driving force behind that involvement. ${ }^{312}$ The poor outcome of the war for Lübeck led to Jurgen Wullenwever's subsequent fall from power, arrest, trial and eventually execution, with negative consequences for Joachim as well. He lost his position in Hamburg's city council in 1536, and in the same year the Hamburg chronicle records Koppen and

308 Evensen, Savn til Føroyinga sögu, no. 30; HR IV, 1, no. 173, p. 154n4; Lappenberg, “Joachim Wullenwever”, 129-130; Degn, Nøkur gomul, áður óprentað brøv, 13.

309 HR IV, 1, no. 173; Hammel-Kiesow, "Die Politik des Hansetags”, 202.

310 Zachariasen, Føroyar, 165.

311 On this episode in greater detail, see Zachariasen, Føroyar, 168-175.

312 Dollinger, Die Hanse, 425-426. 
Wullenwever as having had a falling-out. ${ }^{313}$ In 1535 , Joen Nielsen is mentioned as lawman and governor of the Faroes under Thomas Koppen. ${ }^{314}$ Although the trade between Denmark-Norway and the Faroes was allowed again in 1547, ${ }^{315}$ Koppen remained the only foreign merchant with permission to trade there until his death in 1553. Afterwards, the monopoly trade was lifted and the Bergen staple regained control over the Faroes, ${ }^{316}$ although Koppen's widow Elisabeth received permission to trade there one more year to collect her deceased husband's outstanding debts. ${ }^{317}$ Curiously, it appears she might have given this task to Wullenwever, who is listed on the ships to the Faroes in the donation register of the confraternity of St Anne in 1554. ${ }^{318}$

The monopoly was introduced again by the king in 1557, with the argument that Thomas Koppen had allowed the Faroese to trade with foreign (i.e. German) merchants. ${ }^{319}$ The timing of this measure is curious, three years after Koppen's death, and after he had held the monopoly for 23 years. The real reason is more likely that the Faroese had been trading with Hamburg merchants after Koppen's death as well, as is suggested by the Hamburg donation register, which lists ships sailing to the Faroes until 1557, thereby violating the Bergen staple. ${ }^{320}$ The royal monopoly was now granted to various merchants from Copenhagen. ${ }^{321}$ However, the Faroese people were apparently quite unhappy with how these merchants conducted the trade. Their primary need in terms of imports was timber for the construction of houses and ships, and as early as 1559, Frederick II

313 Lappenberg, "Joachim Wullenwever”, 129.

314 Debes, Føroya søga, 2:61; Degn, Nøkur gomul, áður óprentað brøv, 19. See Section 4.4.2.

315 Evensen, Føroyar, 182-183.

316 NRR I, 162; Evensen, Savn til Føroyinga sögu, nos. 75-77, 78; Debes, Føroya søga, 2:61; Joensen, Mortensen, and Petersen, Føroyar undir fríum handli, 190.

317 Evensen, Savn til Føroyinga sögu, no. 60; Zachariasen, Føroyar, 184; Kohl, "Überseeische Handelsunternehmungen”, 427n1.

318 SAH 612-2/5, 2 vol. 1 (15330000HAM00), f. 130v. This suggests that Wullenwever had not yet been banished from Hamburg; he would die in exile in Malmö in 1558 (cf. Lappenberg, "Joachim Wullenwever", 130.)

319 Evensen, Savn til Føroyinga sögu, nos. 83-84; Zachariasen, Føroyar, 184.

320 Kurt Piper, Verzeichnis der Hamburger Färoerfahrer 1543-1593, 1988, lists, based on the donation register, ships to the Faroes in 1560 and 1561 as well, but this is only based on the fact that merchant Hans Swake was on board, who is recorded as having been on ships to the Faroes until 1557. It is more likely that the 1560 and 1561 ships sailed to Shetland, where Swake is also attested in 1562. This is corroborated by his absence from the donation register in 1558 and 1559 as well.

321 1556: Mikkel Skriver, 1559: Andres Jude, 1569: Andres Jude and Matz Lampe. See Appendix B. For this period see Zachariasen, Føroyar, 184-187. 
ordered councillor Christoffer Valckendorf to sail from Bergen to the Faroes with timber. $^{322}$ In 1570, the Faroese complained again that the Copenhagen merchants were not supplying them with enough commodities (especially timber), ${ }^{323}$ in response to which Frederick II abolished the trade monopoly again the next year. ${ }^{324} \mathrm{He}$ also granted the Faroese permission to keep a ship of 24 lasts to fetch timber from Norway. ${ }^{325}$

In this period, Hamburg merchants appear on the scene again, but exclusively in the role of royal Danish factors who cooperate with Danish and Norwegian merchants. Joachim Thim, factor of the Danish king in Hamburg, received the right to trade with the Faroes in $1573 .{ }^{326}$ This does not mean that the monopoly was reinstated, however. Contrary to the monopolies of Thomas Koppen and the Danes, Thim's licence grants him the right to trade in the Faroes, but does not require him to collect taxes for the Danish king. Moreover, it states explicitly that inhabitants are not obliged to trade with him. Curiously, this arrangement falls right in the period in which the Danish king prohibited Hamburg merchants from sailing to many, and eventually all, Icelandic harbours and other places in the Danish realm.

Possibly Thim did not use his licence in the beginning, or chartered ships from Denmark to sail for him, as the account books of St Anne confraternity do not list him in the Faroes until 1584. ${ }^{327}$ The latter option seems plausible, as he was granted the monopoly in autumn of 1581, in partnership with Magnus Heinesen, a Bergen privateer, seafarer, and merchant who was born in the Faroes and had received the monopoly in $1579,{ }^{328}$ and Jørgen Kydt from Copenhagen. ${ }^{329}$ Earlier in 1581 Heinesen had complained about a merchant from Hamburg who had come to the Faroes the year before and had bought all the available merchandise. Heinesen captured the ship and took it to Bergen, where his goods were confiscated. $^{330}$ The Hamburg merchant apparently found some sympathy with the

322 Evensen, Savn til Føroyinga sögu, no. 90.

323 KB 1566-1570, pp. 316, 477-478.

324 Joensen, Mortensen, and Petersen, Føroyar undir fríum handli, 9, 190.

325 Evensen, Savn til Føroyinga sögu, no. 128.

326 Evensen, no. 138.

327 SAH 612-2/5, 2 vol. 1 (15330000HAM00); Piper, Verzeichnis der Färoerfahrer, 35-36.

328 KB 1576-1579, pp. 558-559; Evensen, Savn til Føroyinga sögu, no. 145. Magnus Heinesen was born around 1545 on the island of Eysturoy, where his Norwegian father was priest. After moving to Bergen in 1566, he sailed regularly between Bergen and Norway and subsequently served in the Dutch navy before returning to the Faroes in 1579. Troels Lund, "Heinesen, Mogens", Dansk Biografisk Lexikon (Copenhagen, 1905 1887); see also Zachariasen, Føroyar, 118-124.

329 Evensen, Savn, nos. 165, 166; Joensen, Mortensen, and Petersen, Føroyar, 10.

330 Evensen, Savn til Føroyinga sögu, nos. 157, 159. 
Faroese, as Heinesen had not been able to meet their needs and arrived too late in the Faroes. ${ }^{331}$ The identity of this Hamburg merchant is unknown, but it could have been Thim, who was ordered to cooperate with Heinesen and Kydt the year after. The reason for inclusion of Kydt in the company was that one ship was to sail to Copenhagen to return the king's tax revenue.

The cooperation between the three merchants was not successful, as Magnus Heinesen was prosecuted by Christoffer Valckendorf and fled to Holland in 1584, which also led to troubles for Thim. ${ }^{332}$ Curiously, 1584 is the only year in which Thim is recorded in the donation register as having been in the Faroes. ${ }^{333}$ In 1586, a new monopoly was granted to Joachim Wichman, the new Danish factor in Hamburg, and councillor Oluf Matzen of Copenhagen for ten years. ${ }^{334}$ Joachim Wichman did avail himself of the opportunity to trade, as a ship sailed each year to the Faroes from Hamburg from 1586 onwards, but the arrangement did not last for the indicated ten years either. Oluf Matzen allegedly illegally sold his right to the monopoly on to someone else, and Wichman ended his involvement in the Faroese trade in 1591, sending a last ship there in 1592 to collect his debts on the island, after which the monopoly was returned to merchants from Copenhagen. ${ }^{335}$ Wichman died in 1592, possibly from disease, which might also have been the reason he ceased trading with the Faroes. On the other hand, he still had many debts at the Danish court, which the king reduced to 1000 daler, because Wichman had always served him well and had encountered many difficulties in the Faroes. ${ }^{336}$ Among them might be a possible shipwreck on his last voyage. After 1591 he is not specifically mentioned in

331 Evensen, no. 160.

332 Joensen, Mortensen, and Petersen, Føroyar undir fríum handli, 10. Magnus Heinesen was ultimately executed in Copenhagen in 1589, convicted of piracy against the English. Lund, "Heinesen, Mogens", 275.

333 This might have had something to do with a letter of King Frederick II to Christoffer Valckendorf of 11 April 1584, in which the former requests the cancellation of the monopoly for Thim be reconsidered, because it was not Thim's fault: Evensen, no. 177 after RAK Danske Kancelli, Sjællandske Tegnelser XV, ff. 331v-332r. Interestingly, the text of the document suggests that Heinesen (who is not mentioned by name) was Thim's brother-in-law: "icke for hans forseellße forßommelße eller muttwillige handeling men en deell formedellst, en hans swogers forßommellße".

334 Evensen, Savn til Føroyinga sögu, nos. 187, 204.

335 KB 1588-1592, pp. 452, 686, 774; Zachariasen, Føroyar, 290-291.

336 KB 1588-1592, p. 822. 
the donation register of St Anne's confraternity again. ${ }^{337}$ With Wichman's death, Hamburg presence in the Faroes ended as well. ${ }^{338}$

\subsection{Scottish rule in Shetland after 1469}

Since Orkney and Shetland were pawned to Scotland by the Danish king in 1469, they followed a separate development from the other Norwegian tributary lands. However, the transfer of political power initially did not change the situation on the islands much. The earls of Orkney, to which both archipelagos belonged, had been of Scottish descent since the thirteenth century, and especially in Orkney Scottish connections were strong. ${ }^{339}$ Shetland, however, remained linked culturally $^{340}$ and commercially to Norway after 1469 and the Norse system of government was initially kept intact. In practice, the sheriffs (called fouds) on Shetland governed the islands, which included regulating foreign trade. ${ }^{341}$ In marked contrast with Iceland and the Faroes, the Scottish Crown did not interfere in the German trade at all until the middle of the seventeenth century.

The absence of royal intervention also makes it difficult to assess the politicaleconomic situation on the islands before the seventeenth century, as it resulted in a lack of sources. No trade regulations for the Shetland trade were enacted in the fifteenth and sixteenth centuries, and there was no ban on the winter stay. Even though merchants stayed in winter from time to time, this was uncommon, as the fishing in Shetland mainly took place in the summer and there was therefore little reason to stay during winter. ${ }^{342}$ Moreover, licences for the use of certain harbours were issued by the foud, not by the king, and do not seem to have been issued systematically. ${ }^{343}$ Maybe because of the lack of a licence system, we know very little about disputes between merchants from different countries or cities. ${ }^{344}$

337 “Anno 1592 de entfanginge [. . . ] van selige Jochim Wichmans 3 schepen up Feroe”. Piper, Verzeichnis der Färoerfahrer, 37-45. No. 54. Wichman (without the addition "selige") had donated to the confraternity the year before.

338 For the Danish monopoly holders from 1591 onwards, see Joensen, Mortensen, and Petersen, Føroyar undir frum handli, 10-11; Zachariasen, Føroyar, 219-237; and Appendix B.

339 Smith, Shetland Life and Trade, 8.

340 Norn, the Shetland dialect of Old Norse, was still spoken on the islands well into the eighteenth century.

341 SD 1195-1579, pp. 306-308; Smith, Shetland Life and Trade, 15.

342 Smith, 15. See Section 2.1.2.

343 Smith, 15-16. See Section 5.2.

344 Smith, 36 (timeline), 39, mentions in passing attacks by Shetlanders on German merchants and attempts by the foud to prohibit foreign trade in 1521 . However, he gives no source 
Merchants from Bremen are the first Germans to be mentioned as having established frequent direct connections with Shetland. A letter from the Bergen Kontor to the Hanseatic Diet in 1498 noted that Bremen merchant Hinrick Kummertho was sailing to Shetland every year. ${ }^{345}$ Even though the explicit ban of the Shetland trade remained in place, it is likely the pawning of Shetland to Scotland meant that the consequences of violating the ban were less dire than before, encouraging Bremen merchants to take the calculated risk of ignoring the Bergen privileges. While Bremen merchants were dominant in Shetland until the seventeenth century, they were joined by merchants from Hamburg, the first of which can be traced to 1547, and also occasionally by merchants from other towns. ${ }^{346}$ There is no evidence for Friedland's contention that the appearance of Hamburg merchants on Shetland was related to the end of Koppen's monopoly on the Faroes in $1553 .^{347}$ After all, Hamburg merchants continued to sail to the Faroes for a few years afterwards. A connection with Hamburg attempts to make the city a staple port for the stockfish trade during the sixteenth century, or with Danish attempts to limit Hamburg's dominance in Iceland, which started in 1547 when King Christian III gave the island to the Copenhagen merchants, is more plausible. Indeed, an annual Hamburg presence in Shetland starts in the mid-sixteenth century, and the annual number of ships rises to two to five after 1600, indicating that some merchants active in the Icelandic trade had switched to Shetland. ${ }^{348}$ On average, we can say ten to twelve foreign ships a year traded with Shetland during the seventeenth century. ${ }^{349}$

The situation started to change in the second half of the sixteenth century, when Scottish landowners settled in Shetland in ever-greater numbers. ${ }^{350}$ Many of these landowners, who often also had landed interests in Norway, established trading links with Norway and were hostile towards the German traders, who mainly dealt with the tenants directly. Some of them tried actively to disrupt the

for these statements, and they do not seem to fit with the otherwise unproblematic attitude of Shetlanders towards foreign traders in the first half of the sixteenth century. I would like to thank Brian Smith for sharing this information.

$345 H R$ III, 4, no 68. See Section 3.4.1.

346 Friedland, "Shetlandhandel", 71; Friedland, "Hanseatic Merchants", 90-91. Friedland's conjecture that merchants from Deventer and Kampen possibly sailed to Shetland around 1498 is based on a very liberal reading of $H R$ III, 4, no. 79, par. 198 and must be considered merely a hypothesis.

347 Friedland, "Shetlandhandel”, 72.

348 Friedland, "Hanseatic Merchants”, 91; Friedland, "Shetlandhandel”, 73.

349 Smith, Shetland Life and Trade, 14.

350 Linda Riddell, “Shetland's German Trade - on the Verge of Colonialism?”, Northern Scotland 10 (2019), 3-5. 
German North Atlantic trade, which resulted in a considerable number of cases of piracy around Shetland and also affected merchants travelling to and from Iceland (Table 3.1). ${ }^{351}$ The unstable political situation in Scotland at the time, caused by dynastic troubles, interference from the English, and Protestant nobles who were rebelling, did not help. One of the most notable cases of piracy in Shetland around this time was the "theft" of one ship each from Bremen merchant Gerdt Hemeling and an unnamed Hamburg merchant by James Hepburn, Earl of Bothwell, who was pursued by the Scottish navy in 1567. Bothwell, the third husband of Mary Stuart, Queen of Scots, was a controversial figure in Scottish politics of the time, and had to flee the country when Mary was captured by rebel Protestant nobles. He first made his way to Shetland (he had been made Duke of Orkney and Shetland the same year), where he lost one of his ships. Bothwell then forced the German merchants in Shetland to rent out their ships, which he never returned. He was driven to Norway after a subsequent battle at sea, and was imprisoned by the Danish governor in Bergen. It seems the German merchants were never compensated for their losses, even though Hemeling went to great lengths to convince the Danish king to prosecute Bothwell for him. ${ }^{352}$

Unlike in Iceland and the Faroes, foreign international trade was never officially prohibited in Shetland. It simply became less and less attractive for German traders in the last decades of the seventeenth century, due to a combination of factors. First, there were the many wars in the North Sea, between the Dutch Republic and England and between England and France, which added risk to the endeavour. In particular, the Nine Years' War (1688-1697), in which the French deployed privateers around Shetland, and the War of the Spanish Succession (1701-1714) proved especially disruptive, and forced Bremen and Hamburg merchants to relocate to Stade, which was occupied by neutral Sweden. Here they acquired Swedish sea passes for safe conduct. ${ }^{353}$ Moreover, there was an economic crisis in the 1690s, combined with a smallpox epidemic in 1700, which also affected the Shetland landowning elite. Some of the large landowners started to trade with the European mainland themselves to supplement the reduced income from landowning, thereby competing with the German merchants. ${ }^{354}$

Other difficulties with the Shetland trade resulted from efforts by the EnglishScottish crown to discourage foreign trade and fisheries and to stimulate the

351 Smith, 29-32, 43.

352 SD 1195-1579, nos. 164, 166, pp. 124-125. See also Section 7.3.

353 Claus Tiedemann, Die Schiffahrt Des Herzogtums Bremen Zur Schwedenzeit (1645-1712) (Stade, 1970), 43-44; Zickermann, Across the German Sea, 90-91.

354 Smith, Shetland Life and Trade, 44-45; Smith, "Shetland and Her German Merchants", 149-151; Riddell, "Shetland's German Trade", 8. 


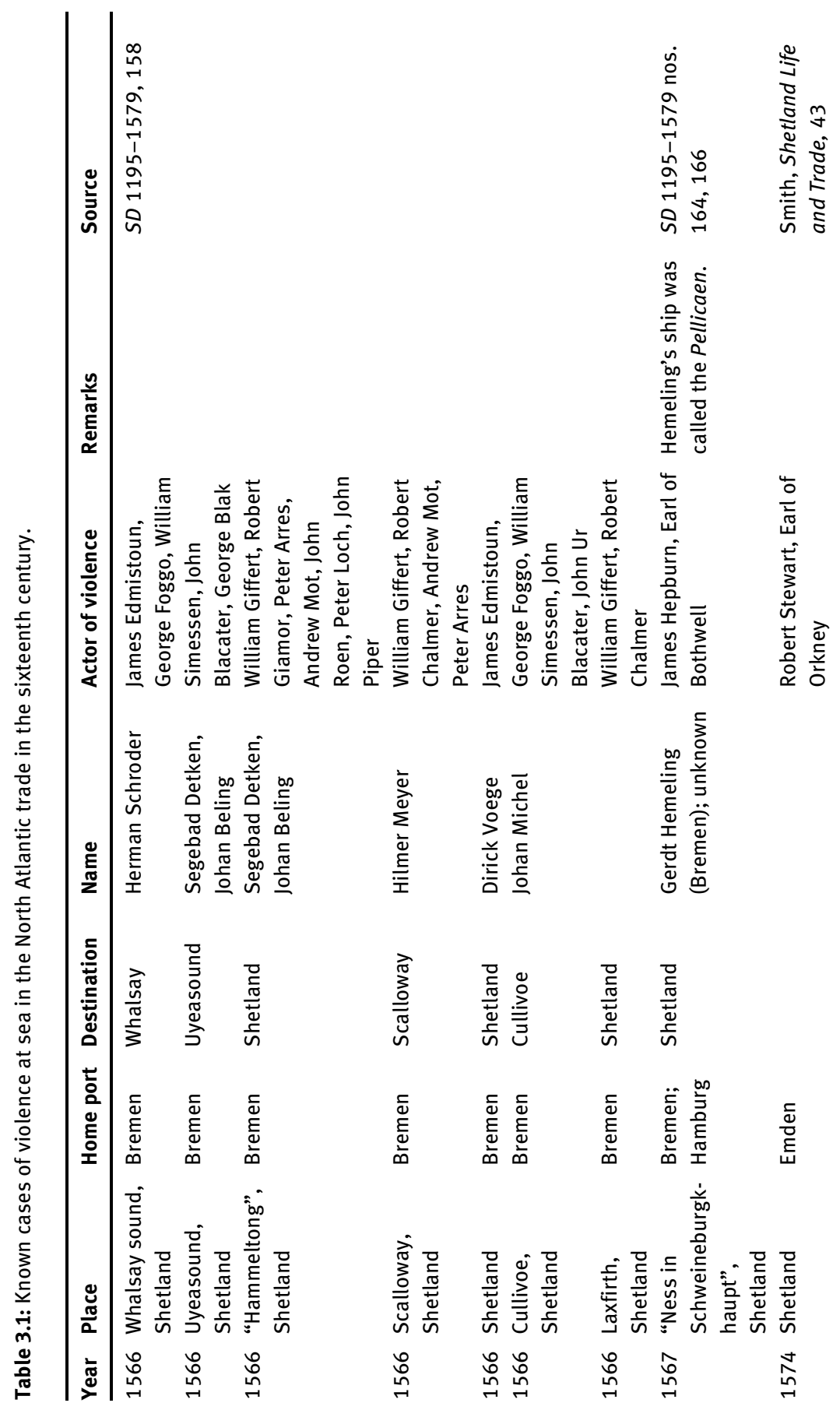




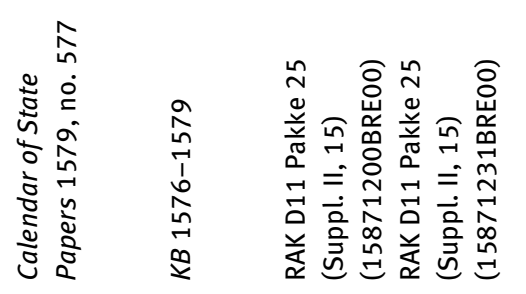

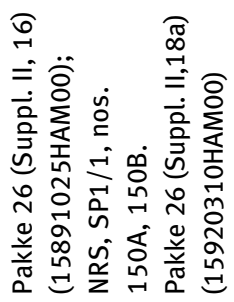

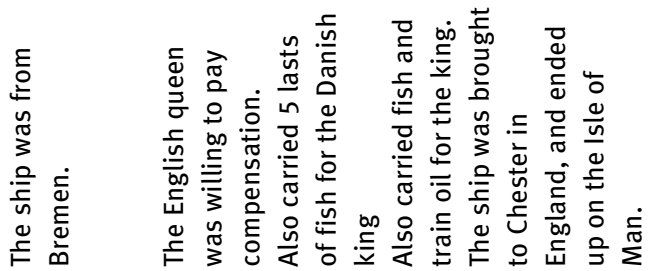

$\frac{\grave{0}}{\frac{2}{n}}$

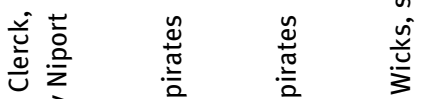

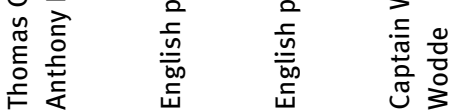

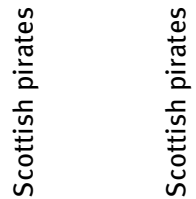

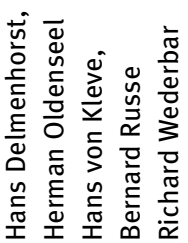

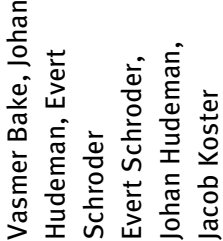

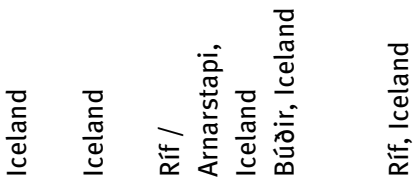

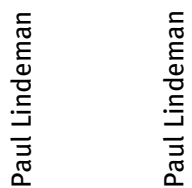

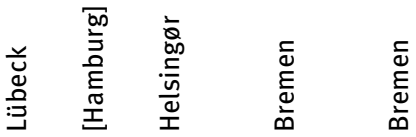

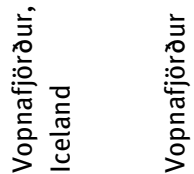

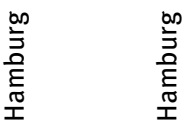

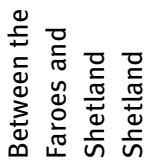

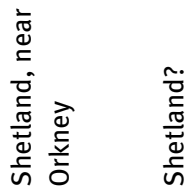

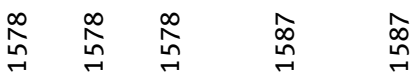

$\stackrel{\infty}{\infty} \stackrel{\circ}{\leftrightarrow}$ 
English and Scottish economy. These took the form of rising customs fees on imports to Scotland from the 1660s onwards. German merchants are even known to have borrowed money from Shetlanders to pay these fees. ${ }^{355}$ Bremen merchants protested heavily against these increases, especially as they seem to have been used by local landowners to extract additional taxes illegally. ${ }^{356}$ Their arguments were that the higher taxes were detrimental to the Shetland economy, which was dependent on foreign imports, and that it was unfair that they had to pay customs for commodities that they did not sell, e.g. beer they drank themselves or salt they used to cure fish. ${ }^{357}$

The final blow to the German Shetland trade came with the Treaty of Union in 1707, which united the kingdoms of England and Scotland. Although this also introduced new taxes on foreign trade, it probably was the assertion of English navigation laws that forced the German merchants to abandon the Shetland trade. These prohibited the import of foreign salt, needed to cure the fish bought in Shetland, aboard foreign vessels into the United Kingdom. Indeed, evidence for Bremen and Hamburg merchants in Shetland disappears shortly afterwards; the last ship from Bremen is documented in 1711. Their trade was taken over by English and local merchants, who still exported the fish to Bremen and Hamburg, which remained the main markets for this commodity. ${ }^{358}$

355 Zickermann, Across the German Sea, 87-88.

356 SAB 2-W.9.b.10.: Bremen complaints, 12 November 1661 (16611112BRE00); Smith, Shetland Life and Trade, 39.

357 SAB 2-R.11.kk.: Bremen complaints about Shetland customs, 1671 (16711026BRE00) and 1679 (16791216BRE00).

358 Zickermann, Across the German Sea, 92-94; Smith, Shetland Life and Trade, 40-42. 